Universidade de Brasília

Faculdade de Ciência da Informação

Programa de Pós-Graduação em Ciência da Informação

ÍVINA FLORES MELO KUROKI

DEMARCAÇÕES CONCEITUAIS DOS PRINCÍPIOS CIENTÍFICOS DA ARQUIVOLOGIA E DA CIÊNCIA DA INFORMAÇÃO:

Contribuições para a configuração científica das disciplinas no Campo da Informação

Brasília-DF

2016 
ÍVINA FLORES MELO KUROKI

\title{
DEMARCAÇÕES CONCEITUAIS DOS PRINCÍPIOS CIENTÍFICOS DA ARQUIVOLOGIA E DA CIÊNCIA DA INFORMAÇÃO: \\ Contribuições para a configuração científica das disciplinas no Campo da Informação
}

\begin{abstract}
Dissertação de Mestrado apresentada ao programa de Pós-Graduação em Ciência da Informação (PPGCinf) da Faculdade de Ciência da Informação (FCI) da Universidade de Brasília.

Brasília, 05 de fevereiro de 2016
\end{abstract}

Área de concentração: Gestão da Informação.

Linha de pesquisa: Organização da Informação

Orientadora: Prof. ${ }^{a}$ Dr. ${ }^{a}$ Angelica Alves da Cunha Marques

Brasília-DF

2016 
KUROKI, Ívina Flores Melo

Demarcações conceituais dos princípios científicos da arquivologia e da ciência da informação: Contribuições para a configuração científica das disciplinas no Campo da Informação/ Ívina Flores Melo Kuroki- Brasília: CID/UNB, 2016.

141fl. (Dissertação de Mestrado). Orientadora: Prof. ${ }^{a}$ Dr. ${ }^{a}$ Angelica Alves da Cunha Marques

1. Princípio da Proveniência. 2. Organicidade. 3. Qualidades da Ciência da Informação. 4. Campo da Informação. I. Título

K968D 


\section{FOLHA DE APROVAÇÃO}

Título: "Demarcações conceituais dos princípios científicos da Arquivologia e da Ciência da Informação: contribuiçóes para a configuração científica das disciplinas no campo da informação".

Autor (a): Ívina Flores Melo Kuroki

Área de concentração: Gestão da informação

Linha de pesquisa: Organizaçāo da Informaçăo

Dissertaçăo submetida à Comissăo Examinadora designada pelo Colegiado do Programa de Pósgraduaçăo em Ciência da Informaçăo da Faculdade em Ciência da Informaçăo da Universidade de Brasilia como requisito parcial para obtençăo do título de Mestre em Ciência da Informaçäo.

Brasilia, 05 de fevereiro de 2016.

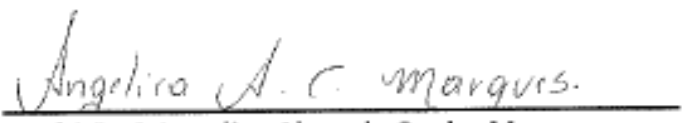

Prof." Dr. ${ }^{a}$ Angelica Alves da Cunha Marques

Presidente (UnB/PPGCINF)

clavisla m. S. Somider

Prof.e Dr.a Clarissa Moreira dos Santos Schmidt

Membro Titular (UFF)

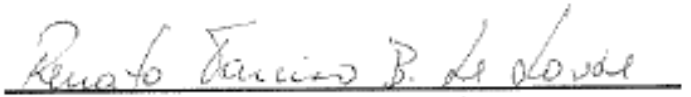

Prof. Dr. Renato Tarciso Barbosa de Sousa

Membro Titular (UnB/PPGCINF)

Prof.a Dr.a Georgete Medleg Rodrigues

Membro Suplente (UnB/PPGCINF)

Editiclo da Bibliotecra Centrel (BCE) - Entrada Leste - Campus Universitário Darcy Fibeiro - Asà Norte - Brasilla, DF CEP 70910-900 - Tel.: +55 (61) 3107-2632 - Telelax +55 (61) 3107 2633 - E-mail: pocint@unb.br 


\section{AGRADECIMENTOS}

Agradeço de sincero coração...

A Deus, pela oportunidade da minha existência terrena.

Aos meus Amigos de Luz, em especial ao meu anjinho querido, obrigada por toda a inspiração e ajuda, pois essa mente humana, limitada, não faria este trabalho sozinha.

Agradeço de alma....

À Angelica, "Angel”, orientadora dedicada, segura e incrível, o anjo que acreditou em mim, segurou a minha mão e alçou esse inigualável voo comigo pelo mundo do conhecimento.

Aos meus pais João e Marli, pelo dom da vida e pelo ensinamento dos valores familiares.

Ao meu esposo George Júnior, que me ouviu e me compreendeu com muito amor e paciência.

Ao meu Joãozinho, que tão pequeno me mudou, de dentro para fora, e me mostrou uma força que eu desconhecia.

Às minhas irmãs Ingrid e Ana Luiza, por serem simplesmente minhas amigas-irmãs.

Às minhas mães de coração Inez (Ziane) e Mieko e ao Papito George Kuroki, pelo amor fraternal.

À minha família gaúcha, que me incentiva de longe com muito orgulho.

À minha família nordestina, que, de maneira peculiar, me ensina a prática da vida cristã.

À minha família japonesa, por me ensinar o real significado da perseverança e da disciplina.

Ao Fernando Gabriel, amigo de estudo, obrigada por todas as conversas e por me ensinar a brandura e a moderação; à Thais Guidolini, ombro amigo arquivístico que sempre se dispôs a escutar minhas angústias e esteve presente a todo momento; e ao José Mauro, pelas várias conversas sobre os desafios de uma pesquisa.

Ao Professor Jayme Leiro, que me auxiliou de maneira tão sutil, mas essencial.

Aos Professores Georgete Medleg, Clarissa Schmidt e Renato Tarciso, obrigada pela credibilidade que suas presenças conferem ao meu trabalho. Saibam que vocês são minha inspiração arquivística! 
"Há uma primavera em cada vida: é preciso cantála assim florida, pois se Deus nos deu voz, foi para cantar! E se um dia hei-de ser pó, cinza e nada que seja a minha noite uma alvorada, que me saiba perder... para me encontrar."

Florbela Espanca 


\section{RESUMO}

O campo da informação, composto de disciplinas científicas cujos objetos concentramse na gênese, organização, recuperação e comunicação da informação registrada, vem sendo perpassado por diversas discussões epistemológicas. As disciplinas que o compõem, embora compartilhem a informação como objeto de estudo, diferenciam-se por seus objetos específicos, seus princípios, seus métodos e suas técnicas. Partindo dessas considerações, esta dissertação tem como objeto de estudo os princípios científicos da Arquivologia e da Ciência da Informação. O seu objetivo geral é compreender as demarcações conceituais dos princípios científicos dessas disciplinas, tendo em vista as suas configurações e os seus diálogos no campo da informação. Com base no levantamento das definições de "princípio científico" e de "teoria", na literatura da Filosofia e da Sociologia da Ciência, analisa o princípio arquivístico da Proveniência na literatura internacional e nacional da Arquivologia, assim como os princípios da Ciência da Informação, na literatura internacional e nacional dessa área. Trata-se de uma pesquisa qualitativa, exploratória, descritiva e explicativa, cujos procedimentos metodológicos consistem na pesquisa bibliográfica dos manuais internacionais e nacionais da Arquivologia e da Ciência da Informação. Dentre os resultados analisados à luz do Método da História Cruzada, esta pesquisa delimita conceitualmente os princípios científicos da Arquivologia e da Ciência da Informação, buscando contribuir com reflexões acerca da trajetória e configuração dessas disciplinas no campo da informação, especialmente, nas particularidades que essas demarcações conceituais podem trazer para cada uma dessas disciplinas no reconhecimento das suas identidades e interlocuções. A análise da trajetória do princípio arquivístico da Proveniência demonstra que a Arquivologia se diferencia das demais disciplinas pela organicidade, entendida, nesta pesquisa, como um macro princípio, isto é, a base fundadora, única e exclusiva na configuração da Arquivologia. A partir da pesquisa bibliográfica, é possível inferir, para a Ciência da Informação, as qualidades da Interlocução Contínua, da Demanda Social e da Disponibilidade da Informação, que fundamentam a evolução científica e a busca por autonomia científica dessa disciplina, ainda que essas qualidades possam ser compartilhadas com a Arquivologia no âmbito dos métodos e das técnicas. Os resultados da pesquisa ainda sugerem que a Arquivologia possui um processo de busca por autonomia mais amadurecido que aquele pelo qual passa a Ciência da Informação, marcada por características híbridas das disciplinas que constituem o campo da informação. A atuação da CI nesse campo parece receber mais do que contribuir, expressando uma natureza interdisciplinar latente e contínua.

Palavras-chave: Princípio da Proveniência. Organicidade. Qualidades da Ciência da Informação. Campo da Informação. 


\begin{abstract}
The field of information, which consists of scientific disciplines focused on the genesis, organization, recovery and communication of registered information, has encompassed several epistemological discussions. The disciplines that compose it, even though they have information as a common object of study, can be distinguished by their specific objects, principles, methods and techniques. In light of these considerations, the purpose of this thesis is to study the scientific principles of Archival and Information Sciences. The general goal is to understand the conceptualization of the scientific principles in these disciplines, considering their configurations and dialogues in the field of information. Building upon a survey of the definitions of "scientific principle" and "theory", within the literary scope of Science Sociology and Philosophy, the research maps the archival principles in the national and international Archival Science literature, as well as the principles of Information Science in the national and international literature of this field of study. It is a qualitative, exploratory, descriptive and explanatory research study, and its methodological proceedings include bibliographical research of national and international Archival and Information Sciences manuals. Among the results analyzed in accordance with the Entangled History Approach (Histoire Croisée), the research defines the concepts of the scientific principles of Archival and Information Sciences, seeking to contribute with reflections on the trajectory and configurations of these disciplines in the field of information, especially regarding the particularities these conceptual definitions may bring to each one of these disciplines in acknowledging their identities and interlocutions. The analysis of the trajectory of the archival principle of Provenance shows that Archival Science differs from other disciplines for its organicity, understood in this research as a macro principle, i.e., a unique, exclusive and fundamental basis in the configuration of Archival Sciences. Taking this bibliographic research as a starting point, it is possible to infer, for the Information Science, the qualities of Continuous Interlocution, Social Demand and Information Availability, which found the scientific evolution and the search for scientific autonomy of this discipline, even though these qualities may be shared with Archival Sciences where methods and techniques are concerned. The results of the research further suggest that Archival Science has a more developed process of search for autonomy than that of Information Science, distinctive for the hybrid characteristics of the disciplines that constitute the field of information. Its performance on this field seems to take more than gives, expressing a latent and continuous interdisciplinary nature.
\end{abstract}

Keywords: Principle of Provenance. Organicity. Information Sciences Qualities. Field of information. 


\section{LISTA DE SIGLAS E ABREVIATURAS}

CI - Ciência da Informação

DIARQ - Diretoria de Arquivos Institucionais

FHETA - Fundamentos Históricos, Epistemológicos e Teóricos da Arquivologia

PPGCI - Programa de Pós-Graduação em Ciência da Informação

PPGCINF - Programa de Pós-Graduação em Ciência da Informação

PROIC - Programa de Iniciação Científica

UFMG - Universidade Federal de Minas Gerais

UnB - Universidade de Brasília 


\section{LISTA DE FIGURAS}

\begin{tabular}{|lll|}
\hline Figura 1 & Graus de flexibilização da objetividade científica segundo & 42 \\
& Popper (2013), Kuhn (2013), Trigueiro (2012) e Weber & \\
& (2006) & 45 \\
Figura 2 & Visão de Popper (2013) sobre enunciados, teorias e & \\
& princípios & 47 \\
Figura 3 & Visão de Kuhn (2013) sobre a evolução da Ciência & \\
& Normal & 48 \\
Figura 4 & Nossa interpretação da visão de Trigueiro (2012) sobre & 49 \\
& princípios científicos & \\
Figura 6 & Nossa intepretação da visão de Weber (2006) para \\
Figura 7 & princípio científico & 88 \\
Figura 8 & Ciclo da Informio da Proveniência e suas relações & 92 \\
Figura 9 & Qualidades da CI e suas relações & 110 \\
\hline
\end{tabular}




\section{LISTA DE QUADROS E TABELAS}

Quadro 1 Manuais arquivísticos internacionais segundo a literatura da área 23 (1898-2000) utilizados na pesquisa

Quadro 2 Manuais arquivísticos nacionais utilizados na pesquisa 26

Quadro 3 Livros da Ciência da Informação utilizados na pesquisa 28

Quadro 4 Síntese da concepção de "ciência” em Popper (2013), Kuhn 39 (2013), Trigueiro (2012) e Weber (2006)

Quadro 5 Síntese da concepção de "objetividade" em Popper (2013), Kuhn 40 (2013), Trigueiro (2012) e Weber (2006)

Quadro 6 Contribuições, segundo Popper (2013), Kuhn (2013), Trigueiro 44 (2012) e Weber (2006), para os objetivos da pesquisa

Quadro $7 \quad$ Síntese da concepção de “teoria” em Popper (2013), Kuhn 50 (2013), Trigueiro (2012) e Weber (2006)

Quadro 8 Síntese da concepção de "ciência” em Popper (2013), Kuhn 51 (2013), Trigueiro (2012) e Weber (2006)

Quadro 9 Aplicação das apropriações conceituais no Campo da Informação 54

Quadro 10 Síntese dos manuais internacionais analisados sobre o Princípio 68 da Proveniência

Quadro 11 Síntese dos manuais nacionais analisadas sobre o Princípio da 72 Proveniência

Quadro 12 Síntese das origens do Princípio da Proveniência segundo os 81 autores estudados na subseção 3.1.2

Quadro 13 Aspectos consensuais dos autores da Ciência da Informação 104

$\begin{array}{lll}\text { Quadro } 14 & \text { Síntese dos autores da CI } & 106\end{array}$

$\begin{array}{lll}\text { Tabela } 1 & \text { Origem institucional dos autores dos manuais analisados } & 83\end{array}$

Tabela 2 Perspectivas do Princípio da Proveniência pelos autores dos 83 manuais elencados por Marques (2011) e estudados na pesquisa

Tabela 3 Número de autores que relacionam o Princípio da Proveniência 86 às funções arquivísticas

Tabela 4 Número de autores conforme o objeto de estudo dos manuais da 107 CI

Tabela 5 Número de autores que relacionam a CI com outras disciplinas 108 científicas 


\section{SUMÁRIO}

1. INTRODUÇÃ

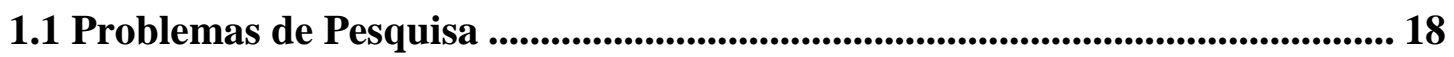

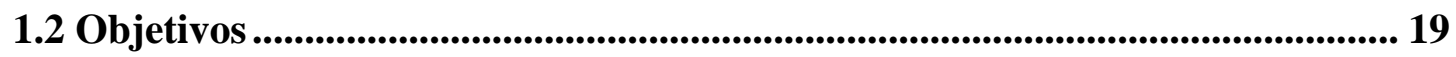

1.2.1 Objetivo geral .................................................................................................................. 19

1.2.2 Objetivos específicos ....................................................................................... 19

1.3 Metodologia de Pesquisa ..................................................................................... 19

1.3.1 Etapas da pesquisa .............................................................................................. 21

1.4 Universo da Pesquisa ........................................................................................................ 29

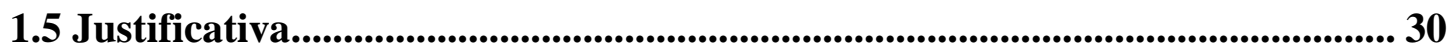

2. A OBJETIVIDADE CIENTÍFICA NA FILOSOFIA E NA SOCIOLOGIA DA CIÊNCIA: ALGUMAS REFLEXÕES REFERENCIAIS ............................. 32

2.1 As fronteiras entre objetividade e "objetividade" científica para a construção da ciência ............................................................................................................................................ 32

2.2 Demarcação dos conceitos de "teoria" e "princípio científico" ...................... 44

2.3 Apropriações da Filosofia e da Sociologia da Ciência no Campo da Informação .....................................................................................................................5 52

3. PRINCÍPIOS ARQUIVÍSTICOS E SUAS CONTRIBUIÇÕES PARA A

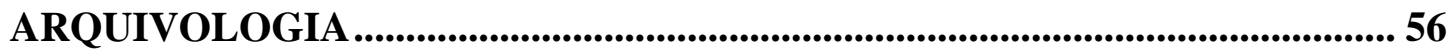

3.1 O Princípio da Proveniência e seus desdobramentos ........................................ 58

3.1.1. Marcos históricos e definições do Princípio da Proveniência: contribuições e repercussões para a trajetória da Arquivologia pela visão

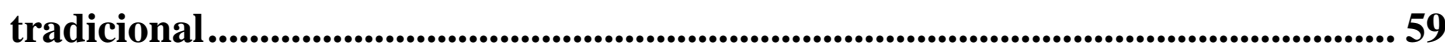

3.1.2 Novos sentidos para a Proveniência ............................................................... 73

3.1.3 Contribuições e repercussões do Princípio da Proveniência para a

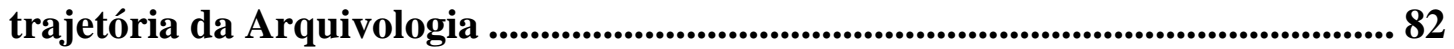

4 OS MANUAIS DA CIÊNCIA DA INFORMAÇÃO: CONSTRUÇÃO DOS PRINCÍPIOS CIENTÍFICOS DESSA DISCIPLINA ....................................... 89

4.1. Teoria do ciclo da informação de Dodebei (2002) ............................................ 90

4.1.1. Produção de conhecimento e registro........................................................ 93

4.1.2. Seleção, aquisição e organização da memória documentária .................... 95

4.1.3. Disseminação e assimilação da informação ............................................ 99 
4.2. Princípios da Ciência da Informação ...................................................... 102

5. CONSIDERAÇÕES FINAIS............................................................................... 111

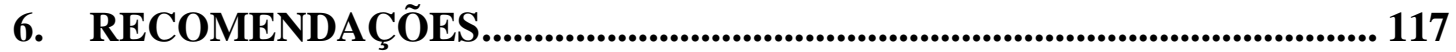

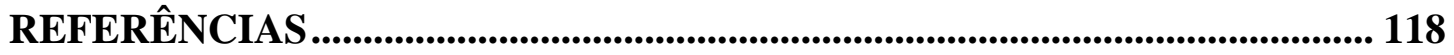

ANEXO A - Manuais Arquivísticos Internacionais............................................. 126

ANEXO B - Manuais Arquivísticos Nacionais ........................................................... 136

ANEXO C - Livros da Ciência da Informação citados nas teses (2007-2009).. 140 


\section{INTRODUÇÃO}

"O empirismo e o senso comum devem ser combatidos ou contrapostos por uma reflexão que resulte no estabelecimento, na elaboração de um novo marco referencial." (SOUSA, 2003, p. 242).

Em abril de 2014, aconteceu o I Ciclo de Palestras da Diretoria de Arquivos Institucionais (DIARQ), na Universidade Federal de Minas Gerais (UFMG). Da palestra proferida pela professora Heloísa Liberalli Bellotto nesse evento, destacamos a seguinte fala:

Um documento arquivístico isolado do seu conjunto não faz sentido. Ele contém, portanto, não uma informação qualquer, mas a que é vinculada a uma vasta cadeia e é parte indissolúvel do seu meio genético de criação, vigência e uso. É a organicidade a grande característica dessa especificidade dos documentos de arquivo. (BELLOTTO, 2014).

Essa afirmação traduz a essência dos arquivos: a organicidade. Pela manutenção da organicidade, observamos os esforços empreendidos pelos pesquisadores da área, que registram suas inquietações na vasta literatura arquivística, assim como pelos arquivistas, na busca pela adequação das atividades de gestão de documentos à teoria arquivística. Da mesma forma, na comunidade científica arquivística, podemos observar que as discussões científicas ganharam, nesse sentido, robustez e vêm trazendo, para a Arquivologia, um amadurecimento científico.

Por outro lado, notamos os avanços científicos da Ciência da Informação (CI), que, embora seja uma disciplina mais recente, ocupa-se da gênese, organização e comunicação da informação, atentando-se para as lacunas deixadas pelas demais disciplinas científicas, tais como a Biblioteconomia, a Museologia e a Documentação.

No cenário epistemológico, entendemos que a Arquivologia estabelece diálogos com outras disciplinas e áreas do conhecimento, inclusive com a Ciência da Informação, e se configura como uma disciplina científica que busca sua autonomia, a partir do delineamento de objeto, princípios, métodos e técnicas próprios, assim como preconizam Marques (2011) e Schmidt (2012).

Historicamente, a Arquivologia começa a formar-se como disciplina científica por volta século XVII (FONSECA, 2005), uma vez que não podemos afirmar ao certo a data da sua origem, a partir da publicação dos primeiros manuais e das circulares governamentais e da delimitação dos princípios arquivísticos (MARQUES, 2011). 
Mais contemporaneamente, a criação de associações profissionais e as discussões científicas registradas nos periódicos e livros, assim como a atuação científica dos pesquisadores da área em eventos científicos, vêm nutrindo essa disciplina, tornando-a parte científica legítima no Campo da Informação (MARQUES, 2011). Destacamos que, na década de 1970, a Arquivologia internacional firmava-se como disciplina autônoma, a partir do desenvolvimento de suas metodologias e do aprofundamento das questões teóricas. No Brasil, situava-se como disciplina com a abertura dos primeiros cursos de graduação em Arquivologia nas universidades públicas (MARQUES, 2007) e a crescente produção científica e de eventos científicos, ou seja, o início do amadurecimento de sua institucionalização.

A Ciência da Informação, por sua vez, tem suas origens, segundo alguns autores (JUVÊNCIO, 2014), relacionadas à área de Documentação, difundida conforme os ideais de universalidade da informação de Paul Otlet e Henri La Fontaine, juristas belgas. Otlet propõe a expansão do conceito de "Documentação" incluindo todos os produtos da informação, inclusive os arquivos (OTLET, 1934).

Para outros autores, como Saracevic (1996), a Ciência da Informação nasce na primeira metade do século XX, na América do Norte, diante da necessidade de se organizarem as informações de forma a subsidiar as ações estratégicas. O autor relata que Vannevar Bush publica um artigo em $1945^{1}$, no qual propõe soluções tecnológicas para tornar as massivas informações acessíveis e passíveis de construções estratégicas no contexto da Guerra. Os pressupostos de Bush contextualizaram a inteligência competitiva e as estratégias de guerras e atribuíram à CI um viés tecnológico, quantitativo e diretamente relacionado com a informática, a cibernética e a criptografia (FREIRE, 2006; SARACEVIC, 1996).

A partir de 1970, período no qual a Arquivologia já se estabelecia como campo de estudo no Brasil, percebe-se que a CI passa a associar as soluções de tecnologia da informação às demandas sociais. Segundo Wersing e Neveling (1996), a CI volta-se para a responsabilidade social, baseada no contexto e na necessidade social de informação. Essa nova perspectiva ampliou ainda mais as possibilidades de diálogos

\footnotetext{
${ }^{1}$ BUSH, Vannevar. As we may think. The Atlantic Monthly, 1945. Disponível em : http://www.theatlantic.com/magazine/archive/1945/07/as-we-may-think/303881/ Acesso em 25 fev. 2016.
} 
com as demais disciplinas, já presentes no nascimento da CI (BORKO, 1968; FREIRE, 2006; GOMES, 2001; MARQUES, 2007).

A partir dessas breves pistas históricas, observamos que, embora os princípios arquivísticos sejam elementos fundadores da Arquivologia como disciplina científica, não havia muitas pesquisas que tratavam especificamente de suas origens e definições. Com o intuito de aprofundar as questões epistemológicas relacionadas à delimitação dos princípios arquivísticos, entre junho de 2011 e agosto de 2012, realizamos um projeto de iniciação científica denominado "Princípios arquivísticos na literatura internacional e nacional: mapeamento do Princípio de Respeito à Ordem Original", desenvolvido no âmbito do Programa de Iniciação Científica (PROIC) da Universidade de Brasília (UnB).

O projeto visou compreender as contribuições do Princípio de Respeito à Ordem Original para o desenvolvimento teórico e epistemológico da Arquivologia, buscando destacar a importância da delimitação desse princípio na trajetória da disciplina. Durante a pesquisa, efetuou-se o estudo sequencial do referido princípio nos manuais internacionais e nacionais elencados na tese de Marques (2011) e buscaram-se os marcos históricos, as definições e as repercussões, bem como os sensos e dissensos dos autores estudados.

Como resultado específico, compreendeu-se que o Princípio arquivístico de Respeito à Ordem Original é elemento fundamental e que, juntamente com a organicidade ou "Princípio da Organicidade" (BELOTTO, 2006) e o Princípio da Proveniência, colabora para a categorização da Arquivologia no âmbito das disciplinas que têm a informação como objeto de estudo, tais como a Documentação, a Biblioteconomia e a Ciência da Informação. Os resultados mais amplos da pesquisa trouxeram reflexões sobre as demarcações conceituais dos princípios arquivísticos, uma vez que a visão dos autores analisados não é consensual.

Tendo em vista o interesse no ingresso em um Programa de Pós-Graduação em Ciência da Informação, iniciamos estudos da literatura nessa área, sobretudo os possíveis princípios dessa disciplina científica, buscando as similaridades entre ela e a Arquivologia. Percebemos que a Ciência da Informação, embora em constantes diálogos e em relações interdisciplinares com diversas disciplinas científicas (BORKO, 1968; FREIRE, 2006; GOMES, 2001; MARQUES, 2007), possui também lacunas quanto ao estudo de seus princípios, até então não identificados. 
Fonseca (2005), por sua vez, ratificou nossa percepção ao afirmar que as relações entre a Arquivologia e a CI merecem maiores estudos e considerações, uma vez que, por terem objetos de estudo muito próximos, ainda que particulares, podem convergir, principalmente quando analisamos seus objetivos, métodos e técnicas embora as aproximações, mais especificamente as relações entre as duas disciplinas, não sejam consenso na literatura de ambas.

Essas reflexões nos inspiraram e trouxeram para esta pesquisa o seguinte questionamento: as acepções de princípio científico, para as duas disciplinas, correspondem, conceitualmente, aos "princípios” em outras disciplinas científicas?

Durante uma reunião ${ }^{2}$ do grupo de pesquisa do Programa de Pós-Graduação em Ciência da Informação (PPGCINF) da UnB, Fundamentos Históricos, Epistemológicos e Teóricos da Arquivologia (FHETA), em março de 2014, o Prof. Dr. Samuel Rodrigues $^{3}$ explanou sobre a definição dos termos "objetividade científica", "enunciados científicos", "princípio científico" e "teoria", para a Sociologia e a Filosofia da Ciência.

Rodrigues (2013) demonstrou, por meio de exemplos da Física - como o princípio da relatividade e a história das teorias de rotação da Terra -, a aplicação desses termos, principalmente no sentido de se fundamentar uma ciência e/ou uma disciplina científica. O pesquisador apresentou uma perspectiva dos princípios como postulados que anunciam temas gerais dentro de uma ciência.

Diante dessa acepção de princípio da Filosofia da Ciência, apresentada por Rodrigues (2013), e observando-se os resultados do PROIC, passou-se a questionar: as definições de princípio científico adotadas pela Filosofia e pela Sociologia da Ciência são efetivamente utilizadas na Arquivologia? Se sim, essas definições seriam válidas para identificar os possíveis princípios científicos da Ciência da Informação?

\footnotetext{
${ }^{2}$ A reunião aconteceu no dia 25 de março de 2014, na sala de reuniões da Secretaria da Pós-Graduação em Ciência da Informação da UnB.

${ }^{3}$ Pós-doutorado pela Universidade de Paris VII/CNRS (04/2008-02/2009), doutorado em Epistemologia pela Universidade de Paris (03/1992-02/1995), especialização (DEA) em Epistemologia pela Universidade de Paris VII (09/1990-02/1992), mestrado em Física pela Universidade de São Paulo (03/1982-08/1984) e graduação em Física pela Universidade de Brasília (08/1973-12/1976). Professor Associado do Departamento de Filosofia da Universidade de Brasília (desde 1995), trabalhando nos seguintes temas: Concepções de Teoria Científica; Descoberta, Justificação e Mudança Científica; Realismo Científico; Explicação e Causalidade; Filosofia da Física. Coordenador do Programa de PósGraduação em Filosofia, Universidade de Brasília. Disponível em: <http://buscatextual.cnpq.br/buscatextual/visualizacv.do?metodo=apresentar\&id=K4781686Z2>. Acesso em: 10 jan. 2015.
} 
Nesta dissertação, apresentamos, no capítulo 2, a delimitação conceitual dos termos "princípio", "teoria", "método" e "técnica", segundo os pressupostos da Filosofia e da Sociologia da Ciência; no capítulo 3, os marcos históricos, as definições e as "novas" visões para o Princípio da Proveniência; no capítulo 4, um mapeamento, nos manuais da CI, de seus possíveis princípios científicos; e, no capítulo 5, as considerações finais da pesquisa, seguidas de algumas recomendações.

\subsection{Problemas de Pesquisa}

Embasamo-nos, para delimitar as questões centrais desta pesquisa, nos pressupostos de Fonseca (2005), Bellotto (2006) e Schmidt (2012). Segundo essas autoras, a Arquivologia, embora dialogue com outras disciplinas e áreas do conhecimento, configura-se como disciplina científica autônoma, portadora de objeto, princípios, métodos e técnicas próprios. Consideramos, também, as contribuições de Rodrigues (2013) sobre a perspectiva dos princípios científicos como postulados que anunciam temas gerais dentro de uma ciência. Dessa maneira, esta pesquisa tem como objeto o estudo dos princípios da Arquivologia e da CI na configuração científica das duas disciplinas e que se traduz nas seguintes questões centrais de pesquisa:

- Quais são os princípios científicos da Arquivologia e da Ciência da Informação que as subsidiam enquanto disciplinas científicas com identidade própria? Esses princípios atenderiam às demarcações conceituais da Filosofia e da Sociologia da Ciência?

- Existem contribuições epistemológicas da Arquivologia para a Ciência da Informação, considerando-se os princípios arquivísticos? Se houver, elas são profícuas para o fortalecimento das relações entre a Arquivologia e a CI? 


\subsection{Objetivos}

\subsubsection{Objetivo geral}

Compreender as demarcações conceituais dos princípios científicos da Arquivologia e da Ciência da Informação, tendo em vista as contribuições desses princípios para a configuração científica dessas disciplinas no Campo da Informação.

\subsubsection{Objetivos específicos}

Considerando-se o problema de pesquisa, elencamos como objetivos específicos:

a) Delimitar conceitualmente "princípio científico" na Filosofia e na Sociologia da Ciência;

b) Analisar o Princípio da Proveniência a partir de mapeamento na literatura arquivística internacional e nacional;

c) Mapear os princípios da Ciência da Informação na literatura internacional e nacional da área.

\subsection{Metodologia de Pesquisa}

Esta pesquisa caracteriza-se como qualitativa, exploratória, descritiva e explicativa. Busca discutir os múltiplos significados do objeto de estudo, visando estabelecer um padrão de interpretação em um espaço de fenômenos, eventos e comportamentos de uma comunidade (CRESWELL, 2003), no caso, a comunidade científica arquivística e da CI, via análise bibliográfica das duas áreas.

O estudo descritivo desta pesquisa objetiva que todas as suas "fases se mostrem interdependentes" (MARQUES, 2007), propondo a identificação dos princípios arquivísticos e da Ciência da Informação, segundo os pressupostos da Filosofia e da Sociologia da Ciência, com vistas a compreender as respectivas contribuições para a configuração das duas disciplinas científicas e possíveis interlocuções no "Campo da Informação" (MARQUES, 2011). 
Dessa forma, optou-se pelo Método da História Cruzada, proposto por Werner e Zimmermann (2003), que propõe a comparação inter-relacional de abordagens teóricas sem, contudo, simplificá-las. Para esses autores, o Método da História Cruzada promove a comparação, considerando-se as esferas sociais historicamente constituídas, proporcionando uma "abordagem mais rica da cultura de recepção" (WERNER; ZIMMERMANN, 2003, p. 95). O entrecruzamento dos fatos desfavorece a superficialidade das análises, enriquecendo as micro e macro características dentre os diferentes espaços, agentes e, no caso desta pesquisa, disciplinas científicas.

Segundo os autores, os aspectos da História Cruzada se referem não apenas a cruzar e "considerar que alguma coisa acontece no momento do cruzamento" (WERNER; ZIMMERMANN, 2003, p. 96); o ponto de análise ou o "ponto de interseção" é amplamente visto como "configurações inter-relacionais", levando-se em consideração as incidências e as repercussões do objeto no respectivo campo de estudo. Os aspectos do cruzamento "não se limitam aos elementos postos em contato, eles podem tocar ainda seu entorno próximo ou distante e manifestar-se segundo temporalidades distintas" (WERNER; ZIMMERMANN, 2003, p. 96).

Tendo em vista o objeto desta pesquisa, a utilização do Método da História Cruzada, sobretudo a fim de se construírem as reflexões teóricas com base na abordagem de diversos autores, atende à necessidade metodológica e traz a complexidade de análises necessárias para que possamos fazer as apropriações conceituais, como propomos em nossos objetivos. Assim, a construção do objeto desta pesquisa vislumbra a adoção de várias perspectivas resultantes de operações de cruzamento (WERNER; ZIMMERMANN, 2003).

Interessa-nos, também, as definições de "campo científico", o que nos guiará no desenvolvimento desta pesquisa. Para tanto, utilizaremos as noções de "campo científico" e habitus de Bourdieu (2011). De acordo com esse estudioso, as práticas sociais ou científicas perpassam diversas camadas do espaço social. Essas camadas são direcionadas e materializadas pelos agentes sociais, que agem dentro de um campo e conforme seu habitus.

O habitus é o "princípio gerador e unificador que retraduz as características intrínsecas e relacionais de uma posição em um estilo de vida unívoco, isto é, em um conjunto unívoco de escolhas de pessoas, de bens, de prática" (BOURDIEU, 2011, p. 21 -22). O habitus caracteriza-se pela experiência vivida (no campo), associada à prática 
social, à trajetória acumulada e à existência social dos agentes nos diversos espaços em que participam. O autor complementa que, na definição de habitus, o pesquisador articula passado (reprodução de estruturas objetivas) e futuro (objetivos contemplados em um projeto).

Desse modo, o campo demonstra as experiências acumuladas pelos agentes sociais, ou seja, é cenário de comportamentos, linguagem e valores. Pelo campo, podese perceber a posição dos agentes nos espaços sociais, por exemplo, os artistas no espaço social artístico, o cientista no espaço social científico e o "japonês" no espaço social da cultura japonesa (BOURDIEU, 2011).

Nesta pesquisa, cabe ressaltar que a contribuição de Bourdieu (2011) apresentase como um fio condutor na análise dos conceitos em estudo. O habitus caracteriza-se pela experiência e tradição a serem discutidas ao longo deste trabalho. O campo científico delimita as disciplinas científicas mencionadas em nossas discussões, o que entrelaça a experiência ligada a contextos históricos, sociais, científicos e de interesses comuns. Como registro do habitus no campo científico, assim como Kuhn (2013) demonstra, observamos os manuais científicos, fonte de registro da tradição científica e das experiências dos autores.

\subsubsection{Etapas da pesquisa}

Com vistas aos objetivos propostos, apresentamos as seguintes etapas metodológicas:

a) Pesquisa bibliográfica tendo em vista a delimitação conceitual de "princípio científico" na Filosofia e na Sociologia da Ciência.

Ao vislumbrar o objeto de estudo desta pesquisa, buscou-se encontrar, mesmo que implicitamente, a conceituação dos termos "princípio" e "teoria" na literatura da Filosofia e da Sociologia da Ciência por meio de pesquisa bibliográfica ${ }^{4}$.

\footnotetext{
${ }^{4}$ A partir das referências bibliográficas apresentadas na palestra do Professor Samuel José Simon Rodrigues, selecionamos dois autores referenciais da Filosofia e da Sociologia da Ciência: Thomas Kuhn e Karl Popper. Incluímos o artigo do professor, enviado após a palestra, e duas obras sugeridas pela Prof. ${ }^{\text {a }}$ Dr. ${ }^{a}$ Fernanda Sobral. Agradecemos a disponibilidade e prontidão dos professores em colaborar para o enriquecimento do arcabouço teórico desta pesquisa.
} 
Fizemos a leitura das obras selecionadas, buscando, nos autores da Filosofia e da Sociologia da Ciência, um fio condutor que pudesse nos guiar quanto à utilização desses conceitos no estudo dos princípios da Arquivologia e da CI no Campo da Informação, culminando na apresentação de quadros sintéticos com as abordagens e apropriações de cada autor.

Necessitamos entender o objeto de estudo da Filosofia e da Sociologia da Ciência, o que também baliza os caminhos científicos de nossas discussões. Trigueiro (2012) observa que as duas disciplinas científicas ocupam-se da construção de uma metateoria sobre a Ciência, ou seja, "uma teoria sobre a atividade científica ou uma teoria sobre as teorias científicas", registradas a partir de uma convenção científica. As teorias científicas, nesse caso, "resultam diretamente de uma prática científica determinada a respeito de um objeto" (TRIGUEIRO, 2012, p. 28).

A reflexão de Trigueiro (2012) e o entendimento dos objetos de estudo da Filosofia e Sociologia da Ciência apoiam esta etapa, pois, segundo o objetivo geral, as duas disciplinas proporcionam à pesquisa as lentes necessárias para a compreensão dos princípios arquivísticos em sua dimensão epistemológica e filosófica. A mesma inferência pode ser aplicada à CI.

Não obstante, as duas disciplinas delimitaram a perspectiva do habitus (BOURDIEU, 2011) e do campo nos quais permeamos esta pesquisa. Dessa maneira, entendemos que a apropriação dos pressupostos da Filosofia e da Sociologia da Ciência foi essencial para a construção teórica deste estudo, sobretudo quanto aos seus constructos teóricos.

b) Análise, segundo a Filosofia e a Sociologia da Ciência, do Princípio da Proveniência na literatura arquivística internacional e nacional.

Esta etapa foi cumprida por meio de pesquisa bibliográfica dos manuais arquivísticos (ANEXOS A e B) elencados na tese de Marques (2011). Justifica-se a escolha dos manuais, pois, enquanto fonte de autoridade, o manual é um grande detentor de capital científico (KUHN, 2013). Segundo Kuhn (2013, p. 83), os cientistas iniciam suas pesquisas a partir de manuais, ou seja, "onde o manual as interrompe”. De acordo com o autor, essa é a evolução natural da pesquisa, e complementa que os livros científicos são "geralmente manuais". No presente trabalho, entendemos como 
"Manual" o que Menezes (2012) denominou "livros". Fizemos essa inferência pois o autor estuda Thomas Kuhn para referendar a sua pesquisa. Dessa maneira, compreendemos que, assim como nesta pesquisa, os manuais/livros são os registros das crises e evoluções dos paradigmas da Ciência Normal.

Com base nos pressupostos de Kuhn (2013), percebemos que o ponto de partida de nossas questões de pesquisa guarda-se nos manuais ou nos livros científicos, como é o caso na etapa metodológica seguinte. Assim, foram suprimidas coletâneas, guias e artigos.

Do rol apresentado por Marques (2011), localizamos 38 manuais arquivísticos internacionais e 11 nacionais, sendo o primeiro o Manual dos Arquivistas Holandeses, de 1898 (MULLER; FEITH; FRUIN, 1960). Essas leituras contemplaram as discussões, pela visão tradicional ${ }^{5}$, do Princípio da Proveniência, conforme os quadros 1 e 2 abaixo:

Quadro 1 - Manuais arquivísticos internacionais, segundo a literatura da área (1898-2000), utilizados na pesquisa

\begin{tabular}{|c|c|c|c|c|}
\hline AUTOR & OBRA & $\begin{array}{l}\text { LOCAL DE } \\
\text { PRODUÇÃO }\end{array}$ & $1^{\mathrm{a}}$ EDIÇÃ̃ & $\begin{array}{c}\text { ANO DA } \\
\text { EDIÇÃO } \\
\text { ANALISADA* }\end{array}$ \\
\hline $\begin{array}{l}\text { MULLER, S.; } \\
\text { FEITH, J. A.; } \\
\text { FRUIN, R }\end{array}$ & $\begin{array}{lr}\text { Handleiding } & \text { voor } \\
\text { ordenen } & \text { en } \\
\text { bescrhreijven } & \text { van } \\
\text { archiven } & \\
\text { (Manual de } & \text { Arranjo e } \\
\text { descrição de arquivos - } \\
\text { Manual } \\
\text { Arquivistas } & \text { dos } \\
\text { Holandeses) } & \end{array}$ & Holanda & 1898 & $\begin{array}{c}1960 \\
\text { (Tradução) }\end{array}$ \\
\hline $\begin{array}{l}\text { JENKINSON, } \\
\text { Hilary }\end{array}$ & $\begin{array}{l}\text { A Manual of archive } \\
\text { administration }\end{array}$ & Inglaterra & 1922 & 1965 \\
\hline $\begin{array}{l}\text { CASANOVA, } \\
\text { Eugenio }\end{array}$ & Archivistica & Itália & 1928 & 1966 \\
\hline BRENNEKE, Adolf & $\begin{array}{l}\text { Archivkunde: ein } \\
\text { Betrag zur Theorie und } \\
\text { Geschichte des } \\
\text { Europäuschen } \\
\text { Archivwesens } \\
\text { (Archives: a } \\
\text { contribution to the } \\
\text { theory and history of } \\
\text { European Archives) }\end{array}$ & Alemanha & 1953 & 1968 \\
\hline
\end{tabular}

\footnotetext{
${ }^{5}$ Entendemos por visão tradicional o estudo e a análise dos manuais arquivísticos que foram elencados por Marques (2011). A seleção da autora foi feita a partir de um estudo sistemático da herança teórica arquivística, segundo os próprios autores da área, sistematizado em um quadro que contemplou: nome do autor, nome da obra original, data de publicação e contribuições para o pensamento arquivístico. Esses manuais, segundo a autora, são registros consagrados na comunidade científica arquivística e compõem a tradição arquivística.
} 
Quadro 1 - continuação

\begin{tabular}{|c|c|c|c|c|}
\hline AUTOR & OBRA & $\begin{array}{l}\text { LOCAL DE } \\
\text { PRODUÇÃO }\end{array}$ & $1^{\mathrm{a}}$ EDIÇÃO & $\begin{array}{c}\text { ANO DA } \\
\text { EDIÇÃO } \\
\text { ANALISADA* }\end{array}$ \\
\hline $\begin{array}{c}\text { SCHELLENBERG, } \\
\text { Theodore }\end{array}$ & $\begin{array}{lr}\text { Modern } & \text { archives: } \\
\text { principles } & \text { and } \\
\text { techniques } & \\
\end{array}$ & $\begin{array}{l}\text { Estados } \\
\text { Unidos }\end{array}$ & 1956 & $\begin{array}{c}2006 \\
\text { (Tradução) }\end{array}$ \\
\hline TANODI, Aurélio & $\begin{array}{l}\text { Manual de } \\
\text { Archivología } \\
\text { Hispanoamericana: } \\
\text { teorias e princípios }\end{array}$ & Argentina & 1961 & 1961 \\
\hline $\begin{array}{c}\text { BAUTIER, Robert- } \\
\text { Henri }\end{array}$ & Les archives & França & 1961 & 1961 \\
\hline $\begin{array}{c}\text { SCHELLENBERG, } \\
\text { T. R. }\end{array}$ & $\begin{array}{lr}\begin{array}{l}\text { Public and private } \\
\text { records: }\end{array} & \text { their } \\
\text { arrangement } & \text { and } \\
\text { description } & \end{array}$ & $\begin{array}{l}\text { Estados } \\
\text { Unidos }\end{array}$ & 1963 & 1980 \\
\hline $\begin{array}{l}\text { ASSOCIATION } \\
\text { DES } \\
\text { ARCHIVISTES } \\
\text { FRANÇAIS }\end{array}$ & $\begin{array}{l}\text { Manuel } \\
\text { d'archivistique: théorie } \\
\text { et pratique des } \\
\text { archives publiques en } \\
\text { France }\end{array}$ & França & 1961 & 1991 \\
\hline $\begin{array}{c}\text { SOCIETY OF } \\
\text { AMERICAN } \\
\text { ARCHIVISTS } \\
\end{array}$ & $\begin{array}{l}\text { Basic Manual Series I } \\
\text { and II }\end{array}$ & $\begin{array}{l}\text { Estados } \\
\text { Unidos }\end{array}$ & 1977 & 1977 \\
\hline $\begin{array}{c}\text { CORTÉS } \\
\text { ALONSO, Vicenta }\end{array}$ & $\begin{array}{l}\text { Documentacion } \\
\text { documentacion }\end{array}$ & Espanha & 1979 & 1980 \\
\hline $\begin{array}{l}\text { HEREDIA } \\
\text { HERRERA, } \\
\text { Antonia }\end{array}$ & $\begin{array}{l}\text { Manual de } \\
\text { organización de fondos } \\
\text { der Corporaciones } \\
\text { Locales. El Archivo de } \\
\text { lar Diputación } \\
\text { Provincial de Sevilla } \\
\end{array}$ & Espanha & 1980 & 1991 \\
\hline $\begin{array}{l}\text { DISPUTACÍON } \\
\text { PROVINCIAL DE } \\
\text { SEVILLA } \\
\end{array}$ & $\begin{array}{l}\text { Archivística: estudios } \\
\text { básicos }\end{array}$ & Espanha & 1981 & 1981 \\
\hline VÁZQUEZ, Manuel & $\begin{array}{l}\text { Manual de selección } \\
\text { documental }\end{array}$ & Argentina & 1982 & 1982 \\
\hline $\begin{array}{c}\text { BERNER, Richard } \\
\text { C. }\end{array}$ & $\begin{array}{l}\text { Archival Theory and } \\
\text { practice in the United } \\
\text { States: a historical } \\
\text { analysis }\end{array}$ & $\begin{array}{l}\text { Estados } \\
\text { Unidos }\end{array}$ & 1983 & 1983 \\
\hline $\begin{array}{c}\text { MATA } \\
\text { CASTILLÓN, José } \\
\text { Manuel; NÚÑNEZ } \\
\text { CONTRERAS, } \\
\text { Luis; HEREDIA } \\
\text { HERRERA, } \\
\text { Antonia } \\
\end{array}$ & $\begin{array}{l}\text { Archivística: estúdios } \\
\text { básicos }\end{array}$ & Espanha & 1983 & 1983 \\
\hline $\begin{array}{c}\text { HEREDIA } \\
\text { HERRERA, } \\
\text { Antonia } \\
\end{array}$ & $\begin{array}{l}\text { Archivística general: } \\
\text { teoría y práctica }\end{array}$ & Espanha & 1984 & 1991 \\
\hline CARUCI, Paola & $\begin{array}{l}\text { Le fonti archivistiche: } \\
\text { ordinamento } \\
\text { conservazione }\end{array}$ & Itália & 1983 & 2010 \\
\hline LODOLINI, Elio & $\begin{array}{l}\text { Archivistica: principi e } \\
\text { problemi }\end{array}$ & Itália & 1984 & 1993 \\
\hline
\end{tabular}


Quadro 1 - continuação

\begin{tabular}{|c|c|c|c|c|}
\hline AUTOR & OBRA & $\begin{array}{l}\text { LOCAL DE } \\
\text { PRODUÇÃO }\end{array}$ & $\mathbf{1}^{\mathbf{a}}$ EDIÇÃO & $\begin{array}{c}\text { ANO DA } \\
\text { EDIÇÃO } \\
\text { ANALISADA* }\end{array}$ \\
\hline $\begin{array}{l}\text { NATIONAL } \\
\text { ARCHIVES AND } \\
\text { RECORDS } \\
\text { SERVICE } \\
\end{array}$ & $\begin{array}{l}\text { A modern archives } \\
\text { reader: basic readings } \\
\text { on archival theory and } \\
\text { practice }\end{array}$ & $\begin{array}{l}\text { Estados } \\
\text { Unidos }\end{array}$ & 1984 & 1984 \\
\hline FAVIER, Jean & Les archives & França & 1985 & 1985 \\
\hline COOK, Michael & $\begin{array}{l}\text { The management of } \\
\text { information from } \\
\text { archives }\end{array}$ & Canadá & 1986 & 1986 \\
\hline PEDERSON, Ann & $\begin{array}{l}\text { The management of } \\
\text { information from } \\
\text { archives }\end{array}$ & Austrália & 1986 & 1987 \\
\hline $\begin{array}{l}\text { LOPEZ GOMEZ, } \\
\text { Pedro; GALLEGO } \\
\text { DOMINGUEZ, } \\
\text { Olga } \\
\end{array}$ & $\begin{array}{l}\text { Introduccion a la } \\
\text { Archivista }\end{array}$ & Espanha & 1989 & 1989 \\
\hline DURANTI, Luciana & $\begin{array}{l}\text { Diplomatics: new uses } \\
\text { for an old Science }\end{array}$ & Canadá & 1989 & 1996 \\
\hline BAILEY, Catherine & $\begin{array}{l}\text { Archival theory and } \\
\text { electronic records }\end{array}$ & $\begin{array}{l}\text { Estados } \\
\text { Unidos }\end{array}$ & $1989-1990$ & -- \\
\hline EASTWOOD, Terry & $\begin{array}{l}\text { The archival fonds: } \\
\text { from theory to practice }\end{array}$ & $\begin{array}{l}\text { Estados } \\
\text { Unidos }\end{array}$ & 1992 & 1992 \\
\hline $\begin{array}{c}\text { DIRECTION DES } \\
\text { ARCHIVES DE } \\
\text { FRANCE } \\
\end{array}$ & $\begin{array}{l}\text { La pratique } \\
\text { archivistique française }\end{array}$ & França & 1993 & 1993 \\
\hline $\begin{array}{c}\text { SOCIETY OF } \\
\text { AMERICAN } \\
\text { ARCHIVISTS / } \\
\text { ASSOCIATION OF } \\
\text { CANADIAN } \\
\text { ARCHIVISTS }\end{array}$ & $\begin{array}{l}\text { Canadian archival } \\
\text { studies and the } \\
\text { rediscovery } \\
\text { provenance }\end{array}$ & Canadá & 1993 & 1993 \\
\hline TAMBLÉ, Donato & $\begin{array}{l}\text { La teoria archivistica } \\
\text { italiana } \\
\text { contemporanea: profile } \\
\text { storico critico (1950- } \\
\text { 1990) }\end{array}$ & Itália & 1993 & 1993 \\
\hline $\begin{array}{l}\text { ROUSSEAU, Jean- } \\
\text { Yves; COUTURE, } \\
\text { Carol }\end{array}$ & $\begin{array}{l}\text { Les fondements de la } \\
\text { discipline archivistique }\end{array}$ & Canadá & 1994 & $\begin{array}{c}1998 \\
\text { (Tradução) }\end{array}$ \\
\hline $\begin{array}{l}\text { CRUZ MUNDET, } \\
\text { José Ramón }\end{array}$ & Manual de Archivística & Espanha & 1994 & 2001 \\
\hline $\begin{array}{c}\text { RUIZ } \\
\text { RODRÍGUEZ, } \\
\text { Antonio Ángel }\end{array}$ & Manual de Archivística & Espanha & 1995 & 2008 \\
\hline $\begin{array}{c}\text { MARTIN- } \\
\text { POZUELO } \\
\text { CAMPILLOS, M. } \\
\text { Paz }\end{array}$ & $\begin{array}{l}\text { La construcción } \\
\text { teórica en Archivística: } \\
\text { el principio de } \\
\text { procedência }\end{array}$ & Espanha & 1996 & 1996 \\
\hline
\end{tabular}

Fonte: Marques (2011).

* Indicamos as obras das quais fizemos a leitura da tradução. 
Quadro 2 - Manuais arquivísticos nacionais utilizadas na pesquisa

\begin{tabular}{|c|c|c|c|}
\hline AUTOR & OBRA & $\begin{array}{l}\text { ANO DA } 1^{a} \\
\text { EDIÇÃAO }\end{array}$ & $\begin{array}{l}\text { ANO DA } \\
\text { EDIÇÃO } \\
\text { LIDA }\end{array}$ \\
\hline $\begin{array}{l}\text { BELLOTTO, } \\
\text { Heloisa Liberalli }\end{array}$ & Arquivos permanentes: tratamento documental & 1991 & 2006 \\
\hline $\begin{array}{l}\text { BELLOTTO, } \\
\text { Heloisa Liberalli }\end{array}$ & $\begin{array}{l}\text { Como fazer análise diplomática e análise } \\
\text { tipológica de documentos de arquivo (Projeto } \\
\text { Como fazer, 8) }\end{array}$ & 2002 & 2002 \\
\hline $\begin{array}{l}\text { BELLOTTO, } \\
\text { Heloisa Liberalli }\end{array}$ & Diplomática e tipologia documental em arquivos & 2008 & 2008 \\
\hline $\begin{array}{l}\text { ESPOSEL, José } \\
\text { Pedro Pinto }\end{array}$ & Arquivos: uma questão de ordem & 1994 & 1994 \\
\hline $\begin{array}{l}\text { JARDIM, José } \\
\text { Maria }\end{array}$ & $\begin{array}{l}\text { Projeto de construção de uma metodologia ibero- } \\
\text { americana de gestão de documentos: relatório da } \\
\text { situação dos arquivos públicos na Argentina, } \\
\text { Brasil, Chile e Uruguai }\end{array}$ & 1987 & 1987 \\
\hline $\begin{array}{c}\text { JARDIM, José } \\
\text { Maria } \\
\end{array}$ & Sistemas e políticas públicas de arquivos no Brasil & 1997 & 1995 \\
\hline $\begin{array}{l}\text { LOPES, Luís } \\
\text { Carlos }\end{array}$ & A informação e os arquivos: teorias e práticas & 1996 & 1996 \\
\hline $\begin{array}{l}\text { LOPES, Luís } \\
\text { Carlos }\end{array}$ & $\begin{array}{l}\text { A gestão da informação: as organizações, os } \\
\text { arquivos e a informática aplicada }\end{array}$ & 1997 & 1997 \\
\hline $\begin{array}{l}\text { LOPEZ, André } \\
\text { Porto Ancona }\end{array}$ & $\begin{array}{l}\text { Como descrever documentos de arquivo: } \\
\text { elaboração de instrumentos de pesquisa (Projeto } \\
\text { Como fazer, 6) }\end{array}$ & 2002 & 2002 \\
\hline $\begin{array}{l}\text { PAES, Marilena } \\
\text { Leite* }\end{array}$ & Teoria e prática de arquivo & 1998 & 1998 \\
\hline $\begin{array}{l}\text { RONDINELLI, } \\
\text { Rosely Curi }\end{array}$ & $\begin{array}{l}\text { Gerenciamento arquivístico de documentos } \\
\text { eletrônicos: uma abordagem teórica de diplomática } \\
\text { arquivística contemporânea }\end{array}$ & 2002 & 2002 \\
\hline
\end{tabular}

Fonte: Marques (2011)

* Este manual foi produzido a partir de uma apostila, fruto de demandas dirigidas à Fundação Getúlio Vargas (FGV), pelas universidades mantenedoras dos cursos de Arquivologia, Biblioteconomia e Documentação, bem como de instituições técnicas e culturais e empresas. (PAES, 1998)

É relevante pontuar que "os avanços das práticas nos arquivos e da Arquivologia como disciplina científica no Brasil são perpassados pela tradução do pensamento arquivístico internacional" (MARQUES, 2011, p. 254). Assim, para que tenhamos um panorama cronológico-histórico dos princípios, iniciamos a leitura pelos manuais internacionais.

A análise foi feita por meio de leituras sequenciais, por ordem cronológica de produção das obras, sintetizadas em um quadro de análise que previu os marcos históricos, as definições e as repercussões, bem como a importância e as contribuições do Princípio da Proveniência para a Arquivologia.

Propomos, também nesta etapa, uma pesquisa bibliográfica de autores que discutem uma nova abordagem para o Princípio da Proveniência, ou seja, outras obras 
não contempladas no mapeamento de Marques (2011). Pelo Método da História Cruzada, fizemos o entrecruzamento desses autores, buscando, sobretudo, novos sentidos e novas aplicações para os princípios arquivísticos.

c) Mapeamento, conforme os conceitos da Filosofia e da Sociologia da Ciência, dos princípios da CI, na literatura internacional e nacional da área.

Para o cumprimento desta etapa, propusemos uma pesquisa bibliográfica dos livros de CI citados nas teses da área e elencados na dissertação de Menezes (2012). Segundo o autor, foram identificados 127 livros, sendo 58 monografias e 69 coletâneas produzidas pelos 14 Programas de Pós-Graduação em Ciência da Informação (PPGCIs) analisados, entre 1998 e 2009. Além dos livros produzidos pelos PPGCIs, foram analisados os livros citados de maneira geral nas teses.

Desse universo, selecionamos ${ }^{6} 22$ livros da Ciência da Informação citados nas teses (2007-2009) ${ }^{7}$, todos listados abaixo, como temas epistemológicos da $\mathrm{CI}^{8}$. Não foram contempladas, no escopo desta etapa, as coletâneas produzidas pelos PPGCIs, pois, para que pudéssemos atingir o objetivo, os livros deveriam ser de autoria única, tendo em vista o desenvolvimento neles apresentados e a continuidade da metodologia por nós escolhida.

\footnotetext{
${ }^{6}$ Mantivemos todos os recortes estabelecidos por Menezes (2012).

${ }^{7}$ A lista completa dos livros se encontra no ANEXO C.

8 Foram excluídos do escopo da pesquisa manuais, livros e coletâneas centrados em temas da Biblioteconomia e da Arquivologia, uma vez que, para o estudo desta etapa, concentramo-nos na CI. Não foram contempladas as coletâneas, uma vez que, segundo Kunh (2013), os manuais são as fontes principais de registro da evolução de uma ciência - no caso desta pesquisa, disciplina científica.
} 
Quadro 3 - Livros da Ciência da Informação utilizados na pesquisa

\begin{tabular}{|c|c|c|c|}
\hline AUTORES & LIVRO & $\begin{array}{l}\text { ANO DA } 1^{a} \\
\text { EDIÇÃAO }\end{array}$ & $\begin{array}{c}\text { ANO DA } \\
\text { EDIÇÃO } \\
\text { ANALISADA }\end{array}$ \\
\hline $\begin{array}{l}\text { SHANNON, Claude; } \\
\text { WEAVER, Warren }\end{array}$ & The mathematical theory of communication. & 1949 & 1962 \\
\hline BRIET, Suzanne & Qu'est-ce la documentation? & 1951 & $\begin{array}{c}\text { Não } \\
\text { localizado }\end{array}$ \\
\hline VICKERY, Brian & $\begin{array}{l}\text { Classificação e indexação nas ciências } \\
\text { Classification and Indexing in Science }\end{array}$ & 1958 & 1975 \\
\hline $\begin{array}{l}\text { LANCASTER, } \\
\text { Frederick }\end{array}$ & $\begin{array}{l}\text { Information retrieval systems: } \\
\text { characteristics, testing and evaluation }\end{array}$ & 1968 & 1968 \\
\hline $\begin{array}{l}\text { LANCASTER, } \\
\text { Frederick }\end{array}$ & $\begin{array}{c}\text { Vocabulary control for information } \\
\text { retrieval }\end{array}$ & 1972 & $\begin{array}{c}\text { Não } \\
\text { localizado }\end{array}$ \\
\hline FOSKETT, Antony & $\begin{array}{l}\text { A abordagem temática da informação } \\
\text { The subject approach to information }\end{array}$ & 1973 & 1973 \\
\hline ROBREDO, Jaime & Documentação de hoje e de amanhã & 1978 & 1978 \\
\hline $\begin{array}{l}\text { GUINCHAT, Claire; } \\
\text { MENOU, Michel }\end{array}$ & $\begin{array}{l}\text { Introdução geral às ciências e técnicas da } \\
\text { informação e documentação } \\
\text { Introduction générale aux Science et } \\
\text { techniques de l'information et de la } \\
\text { documentation }\end{array}$ & 1981 & 1994 \\
\hline MCGARRY, Kevin & $\begin{array}{l}\text { O conceito dinâmico da informação: uma } \\
\text { análise introdutória } \\
\text { Changing Context of Information: An } \\
\text { Introductory Analysis }\end{array}$ & 1981 & 1999 \\
\hline $\begin{array}{l}\text { LANCASTER, } \\
\text { Frederick }\end{array}$ & $\begin{array}{l}\text { Indexação e resumos: teoria e prática } \\
\text { Indexing and abstracting in theory and } \\
\text { practice }\end{array}$ & 1991 & 1993 \\
\hline INGWERSEN, Peter & Information retrieval interaction & 1992 & 1992 \\
\hline KUHLTHAU, Carol & $\begin{array}{l}\text { Seeking meaning: a process approach to } \\
\text { library and information services }\end{array}$ & 1993 & $\begin{array}{c}\text { Não } \\
\text { localizado }\end{array}$ \\
\hline $\begin{array}{l}\text { CINTRA, Anna M. et } \\
\text { al. }\end{array}$ & Para entender as linguagens documentárias & 1994 & 1994 \\
\hline FIGUEIREDO, Nice & Estudos de uso e usuários da informação & 1994 & 1994 \\
\hline $\begin{array}{l}\text { LE COADIC, Yves- } \\
\text { François }\end{array}$ & $\begin{array}{l}\text { A Ciência da Informação } \\
\text { La science de I'information }\end{array}$ & 1994 & 1996 \\
\hline HJORLAND, Birger & $\begin{array}{l}\text { Information seeking and subject } \\
\text { representation: an activity-theoretical } \\
\text { approach to Information Science }\end{array}$ & 1997 & 1997 \\
\hline SVENONIUS, Elaine & $\begin{array}{c}\text { The intellectual foundation of information } \\
\text { organization }\end{array}$ & 2000 & $\begin{array}{c}\text { Não } \\
\text { localizado }\end{array}$ \\
\hline CAMPOS, Maria Luiza & $\begin{array}{l}\text { Linguagem documentária: teorias que } \\
\text { fundamentam sua elaboração }\end{array}$ & 2001 & 2001 \\
\hline DOBEDEI, Vera & $\begin{array}{l}\text { Tesauro: linguagem de representação da } \\
\text { memória documentária }\end{array}$ & 2002 & 2002 \\
\hline $\begin{array}{l}\text { SILVA, Armando } \\
\text { Malheiro; RIBEIRO, }\end{array}$ & $\begin{array}{l}\text { Das "ciências" documentais à Ciência da } \\
\text { Informação: ensaio epistemológico para um }\end{array}$ & 2002 & 2008 \\
\hline
\end{tabular}


Quadro 3 - continuação

\begin{tabular}{|c|c|c|c|}
\hline AUTORES & LIVRO & $\begin{array}{c}\text { ANO DA 1a } \\
\text { EDIÇÃO }\end{array}$ & $\begin{array}{c}\text { ANO DA } \\
\text { EDIÇÃO } \\
\text { ANALISADA }\end{array}$ \\
\hline Fernanda & novo modelo curricular & \\
\hline ROBREDO, Jaime & $\begin{array}{c}\text { Da Ciência da Informação revisitada aos } \\
\text { sistemas humanos de informação }\end{array}$ & 2003 & 2003 \\
\hline
\end{tabular}

Fonte: Menezes, (2012).

Como base metodológica para a organização e o desenvolvimento desta etapa, utilizamos o que entendemos como "Teoria do ciclo da informação de Dodebei (2002)", embora essa opção metodológica não contemple todos os tipos de manuais, tais como os manuais epistemológicos. No entanto, percebemos que a utilização do ciclo promoveu uma melhor compreensão dos manuais.

Por ciclo, fizemos as interlocuções entre os autores e os livros selecionados, conforme propõe o Método da História Cruzada (WERNER; ZIMMERMANN, 2003). A teoria em questão culminou em seis eixos de análise, que coincidem com as seis etapas do referido ciclo: produção de conhecimento, registro, seleção e aquisição, organização da memória documentária, disseminação da informação e assimilação.

A análise foi feita por meio de leituras sequenciais, detalhadas em um quadro de análise que previu o objeto de estudo do manual, a principal atividade da CI, a informação segundo os autores estudados e a relação da CI com outras disciplinas.

\subsection{Universo da Pesquisa}

Para a construção do universo desta pesquisa, embasamo-nos nas definições de habitus e campo científico (BOURDIEU, 2011). Apontamos os autores da Arquivologia e da CI como agentes sociais. Como constructos desdobrados do habitus científico, temos os manuais tanto da Arquivologia quanto da CI, que materializam os discursos dos agentes sociais dentro do espaço social e do campo científico aos quais esta pesquisa se reporta.

Portanto, o universo deste trabalho abrange 49 livros da Arquivologia e 36 livros da CI, entendidos como manuais, na perspectiva de Kuhn (2013), demonstrados nos quadros 1,2 e 3 . 


\subsection{Justificativa}

O Campo da Informação, composto de disciplinas científicas cujos objetos ${ }^{9}$ concentram-se na gênese, organização, recuperação e comunicação da informação registrada, tem, em seu interior, questões epistemológicas em pleno movimento de discussão (MARQUES, 2011). Entende-se que as disciplinas nesse campo, embora compartilhem a informação como objeto de estudo mais amplo, diferenciam-se por seus objetos específicos, princípios, métodos e técnicas. Compreendemos que a Arquivologia e a CI vêm se estabelecendo, no cenário científico, por meio de suas literaturas e pela atuação de suas comunidades científicas, inclusive no Campo da Informação. Percebese, também, que a necessidade de diálogos com outras disciplinas é latente, de modo a preencher lacunas em seus cernes epistemológicos.

A partir do projeto de iniciação científica, pudemos apreender que até mesmo os autores tradicionais da teoria arquivística mantiveram o foco dos respectivos estudos na Arquivologia como um todo, sobretudo nas atividades arquivísticas, nas técnicas e nos meios de recuperação dos documentos. Embora autoras como Marques (2011) e Tognoli (2010) considerem os princípios arquivísticos como parte científica da configuração da Arquivologia como disciplina científica, não pudemos identificar pesquisas, no âmbito de pós-graduação em Ciência da Informação, com esse objeto de estudo.

Ademais, ao observarmos a classificação temática das dissertações e teses, relacionadas à Arquivologia e aos arquivos, mapeadas por Marques (2007), não foi possível destacar muitos títulos que tratassem da epistemologia da Arquivologia, embora as contribuições dos autores para a disciplina possam ser inferidas de pesquisas com temas diversos.

Para a CI, o cenário não é diferente. Pelo estudo bibliográfico de Menezes (2012), percebemos que os livros e coletâneas listados pelo autor preenchem as questões iniciais da origem e do objeto de estudo dessa disciplina científica. Todavia, não há, segundo esse levantamento, estudos que tratem pormenorizadamente dos seus princípios científicos.

\footnotetext{
9 Tomamos por objeto da Arquivologia a informação orgânica registrada e, da CI, a informação registrada. (LECOADIC 1996, MARQUES, 2011; SCHMIDT, 2012)
} 
Diante das lacunas apontadas, consideram-se incipientes as pesquisas no Brasil que contemplam discussões sobre os princípios científicos da CI e da Arquivologia. Ademais, não pudemos identificar trabalhos científicos com base teórica na Filosofia e na Sociologia da Ciência para realizarmos uma demarcação conceitual nesse sentido.

Desse modo, esperamos que este estudo traga à luz uma modesta análise quanto às origens, ao desenvolvimento, às aplicações e às repercussões dos princípios científicos de ambas as disciplinas científicas. Assim, pretendemos realizar um estudo histórico-epistemológico, porém não exaustivo, das origens, definições e contribuições dos princípios científicos da Arquivologia e da Ciência da Informação na formação, no amadurecimento e nas interlocuções dessas disciplinas. 


\title{
2. A OBJETIVIDADE CIENTÍFICA NA FILOSOFIA E NA SOCIOLOGIA DA CIÊNCIA: ALGUMAS REFLEXÕES REFERENCIAIS
}

\begin{abstract}
"Um homem pode sentir-se atraído pela ciência por todo tipo de razões. Entre essas estão o desejo de ser útil, a excitação advinda da exploração de um novo território, a esperança de encontrar ordem e o impulso para testar o conhecimento estabelecido." (KUHN, 2013, p. 107).
\end{abstract}

Neste capítulo, focalizaremos a demarcação conceitual dos termos "objetividade científica", "princípio científico" e "teoria", considerados essenciais para o entendimento do nosso objeto de estudo. Para compreendermos a Filosofia e a Sociologia da Ciência, ou seja, o objeto de estudo dessas disciplinas científicas e sua possível aplicação no estudo epistemológico dos princípios científicos da Arquivologia e da Ciência da Informação, utilizaremos Trigueiro (2012). Baseando-nos no ethos e nas práxis científicas apresentadas por esse autor, tentaremos promover um diálogo entre Popper (2013), Kuhn (2013) e Weber (2006), destacando como pontos centrais os "paradigmas" e a "Ciência Normal" (KUHN, 2013), assim como a "lógica dedutiva" (POPPER, 2013), que contribuirão para as nossas reflexões e para a construção conceitual de "objetividade" científica (WEBER, 2006).

Assim, conforme Popper (2013), Kuhn (2013), Trigueiro (2012) e Weber (2006), buscaremos, segundo o Método da História Cruzada (WERNER; ZIMMERMANN, 2003), o entrecruzamento de propostas, a fim de delinear as definições e torná-las aplicáveis ao nosso objeto. As demarcações das definições de "princípio científico" e "teoria" serão contextualizadas no Campo da Informação (MARQUES, 2011), para a devida apropriação e aplicação às demais etapas desta pesquisa. Passemos às discussões do capítulo.

\subsection{As fronteiras entre objetividade e "objetividade" científica para a construção da ciência}

Estabeleceremos, como ponto de partida conceitual das nossas reflexões, a definição de ethos científico apresentada por Trigueiro (2012). Segundo esse autor, ethos científico é o conjunto de normas e regras de conduta que são seguidas pelos membros de uma comunidade científica (TRIGUEIRO, 2012, p. 28). Nesse sentido, 
devemos observar que a Arquivologia e a CI, no Brasil, estão inseridas na área das Ciências Sociais Aplicadas ${ }^{10}$, cujas "normas e regras" influenciam a abrangência e a aplicabilidade das respectivas atividades científicas. Portanto, as apropriações conceituais propostas neste capítulo observarão essas fronteiras científicas e as características epistemológicas de cada disciplina científica.

Compreendendo-se a proposta de apropriação desta seção, levantamos a questão da objetividade nas atividades científicas, especialmente enquanto ethos da Arquivologia e da CI, no Campo da Informação. A objetividade encontra-se em constante observação na construção dos saberes científicos, sobretudo na maneira com que o cientista, metodologicamente, desenvolve suas reflexões e elabora enunciados, teorias, princípios e leis.

Segundo o Dicionário de Filosofia, a objetividade é:

\begin{abstract}
Em sentido objetivo: caráter daquilo que é objeto; em sentido subjetivo: caráter de consideração que procura ver o objeto como ele é, não levando em conta as preferências ou os interesses de quem o considera, mas apenas procedimento intersubjetivo de averiguação e aferição. Propriedade daquilo que vale independentemente do subjetivo. Por exemplo, fala-se de objetividade dos valores ou do saber científico. (ABBAGNANO, 2012, p. 841).
\end{abstract}

Mesmo que a definição aponte para uma objetividade "não levando em conta as preferências ou interesses de quem considera" (ABBAGNANO, 2012, p. 841), devemos considerar que a aplicação dessa definição nas diversas disciplinas científicas possui intensidades diferenciadas e uma diversidade de abordagens pautadas segundo o sentido e o objeto de estudo em discussão. Por exemplo, enquanto a objetividade nas Ciências Sociais se origina de percepções e entrecruzamentos de conhecimentos, por meio da tradição científica, do compartilhamento e das experiências, a objetividade nas Ciências Exatas vem de experimentos deduzidos da lógica e da falseabilidade. Portanto, quais seriam os sentidos da objetividade nas diferentes disciplinas científicas? A partir das visões de Popper (2013), Kuhn (2013), Trigueiro (2012) e Weber (2006), buscamos traçar e delimitar os conceitos de "ciência" e "objetividade científica", conforme as

\footnotetext{
${ }^{10}$ Considerando a classificação das áreas do conhecimento do Conselho Nacional de Desenvolvimento Científico e Tecnológico $(\mathrm{CNPq})$ atualmente em vigor, disponível em <http://www.cnpq.br/documents/10157/186158/TabeladeAreasdoConhecimento.pdf>, acesso em: 11 nov. 2014. A Tabela de Áreas do Conhecimento (TAC) é uma classificação institucional com fins de fomento à pesquisa científica, a qual utilizaremos como balizador para as discussões desta seção.
} 
diferentes abordagens dos autores estudados. Posteriormente, faremos o entrecruzamento das abordagens, objetivando a demarcação conceitual de "princípio científico" e "teoria".

Para Popper (2013), a ciência é um tipo de conhecimento criado pelos seres humanos e se diferencia dos outros saberes pela articulação de métodos e experimentos, que evidenciam a validade desse conhecimento. Segundo o autor, a ciência se desenvolve a partir da elaboração de teorias e enunciados, que não necessariamente se originam de uma tradição científica conhecida. O trabalho do cientista "consiste em elaborar teorias e pô-las em prova” (POPPER, 2013, p. 30). É possível elaborar teorias experimentais, nunca antes relacionadas às leis e aos enunciados preexistentes, e testálas por meio de experimentos lógicos. Busca-se a objetividade absoluta dos resultados, pelos métodos de falseabilidade e de verificabilidade, a partir da aplicação lógicodedutiva dos enunciados.

Popper (2013) critica as ciências empíricas, pois acredita que elas fundam a respectiva forma lógica no "mundo real ou o mundo de nossas experiências"11, constituindo-se as experiências em um "método peculiar" que as distingue dos demais sistemas teóricos. O método científico consiste em induzir os enunciados singulares "tais como a descrição dos resultados de observações" para "enunciados particulares", "tais como hipóteses ou teorias" (POPPER, 2013, p. 27). Esse método, segundo Popper (2013), denominado "método da indução científica", incorre em resultados incertos e sem coerência científica.

O mesmo autor infere que há uma clara oposição entre a dedução e a indução, visto que, nos sistemas dedutivos, leva-se em consideração a lógica do conhecimento, enquanto que, nos sistemas indutivos, considera-se a psicologia do conhecimento, ou seja, os fatos empíricos e as impressões subjetivas. Popper (2013) complementa:

\begin{abstract}
A minha tese de que uma experiência subjetiva, ou um sentimento de convicção, jamais pode justificar um enunciado científico e de que, dentro dos quadros da ciência, ele não desempenha papel comum, exceto o objeto de uma investigação empírica psicológica. Por mais intenso que seja um sentimento de convicção, ele jamais pode justificar um enunciado. Assim, posso estar inteiramente convencido da verdade de um enunciado, estar certo da evidência de minhas percepções: tomado pela intensidade de minha experiência, toda dúvida pode parecer-me absurda. (POPPER, 2013, p. 47).
\end{abstract}

\footnotetext{
${ }^{11}$ Experiências, neste caso, são tratadas, por Popper (2013), no sentido de compartilhamento de saberes ou de conhecimentos, livre de impressões objetivas.
} 
O problema da demarcação indutiva de Popper (2013) aponta que o caráter empírico e não metafísico dos sistemas teóricos empíricos não oferece elementos lógicos suficientes para a demarcação dos conceitos. $\mathrm{O}$ autor justifica que a objetividade e a avaliação da verdade acabam distorcidas nessas pesquisas. Para ele, "a objetividade dos enunciados científicos reside nas circunstâncias de eles poderem ser intersubjetivamente submetidos a teste" (POPPER, 2013, p. 41). Nessa perspectiva, a ciência não é um sistema de conceitos, tampouco as teorias são empiricamente verificáveis. A ciência é um sistema de enunciados e tem como critério de demarcação a falseabilidade de um sistema, sobretudo pautado na lógica dedutiva.

Kuhn (2013), por sua vez, sustenta que há uma rota para a ciência: uma Ciência Normal baseada em "realizações científicas passadas". As realizações são acordadas por uma comunidade científica, "proporcionando os fundamentos para a prática posterior" (KUHN, 2013, p. 71), por meio de registros em manuais e artigos científicos. Essas realizações são chamadas, pelo autor, de "paradigmas".

A Ciência Normal, para Kuhn (2013), enquanto um conjunto de fatos, teorias e métodos registrados em documentos científicos, advém de experiências e observações dos paradigmas que a alimentam constantemente e determinam a interpretação dos problemas científicos. Os paradigmas partem da base empírica do cientista, considerando-se que as experiências são necessárias e, por conseguinte, ponto central no desenvolvimento da ciência.

A perspectiva de Kuhn (2013) demonstra que os paradigmas estão em constante evolução e, ainda que se procure a imparcialidade nas ciências, as experiências e as tradições científicas originadas de bases empíricas são partes essenciais nas revoluções científicas. Nesse sentido, a "objetividade parcial" situa os paradigmas dentro da comunidade científica. O consenso, ou seja, a aderência da comunidade científica a um paradigma orienta a Ciência Normal (KUHN, 2013) e a continuidade das pesquisas e das novas descobertas.

Para o autor, não temos como abandonar os paradigmas e as questões da base empírica, sobretudo na constante evolução das ciências. Ainda que uma ciência não possua paradigmas universalmente aceitos dentro da comunidade, os problemas que se desdobram da articulação de possíveis paradigmas são "simultaneamente teóricos e experimentais" (KUHN, 2013, p. 100) e não se velam do traço subjetivo do cientista. Kuhn (2013) complementa: 


\begin{abstract}
Já vimos que uma comunidade científica, ao adquirir um paradigma, adquire igualmente um critério para a escolha de problemas que, enquanto o paradigma for aceito podem ser considerados como dotado de uma solução possível. Numa larga medida, esses são os únicos problemas que a comunidade admitirá como científicos ou encorajará seus membros a resolver. Outros problemas mesmo muitos dos que eram anteriormente aceitos, passam a ser rejeitados como metafísicos ou como parte de outra disciplina. Podem ainda ser rejeitados como demasiado problemático para merecerem o dispêndio de tempo. (KUHN, 2013, p. 106).
\end{abstract}

Entendemos, pela análise do autor, que a Ciência Normal se desenvolve a partir da discussão de paradigmas, cuja gênese se dá dentro de uma comunidade científica. Muito embora o autor preconize ainda que o paradigma assente estabilidade na comunidade científica, há ocasiões de crise que a levam a transformações e revoluções constantes.

Kuhn (2013) explana que a ciência passa por momentos pré-paradigmáticos quando se percebe a disseminação de novas ideias e perspectivas, que resultam em dissensos ideológicos dentro da comunidade científica. Segundo ele, "o período préparadigmático é regularmente marcado por debates frequentes e profundos a respeito de métodos, problemas e padrões de solução legítimos" (KUHN, 2013, p. 121). Em seguida, notam-se a discussão e o estudo de um paradigma por meio de soluções de quebra-cabeças, resultando na revolução científica, ou seja, na modificação dos paradigmas, bem como na respectiva adaptação às novas perspectivas da comunidade científica.

Assim como Kuhn (2013), Trigueiro (2012) entende que a ciência se alterna entre períodos de estabilidade e de crise. Segundo ele, a busca pelo "por quê?" sobrepõe-se ao "como?", ao "de que modo?" e ao "como descrever?”. A constante reinvenção da ciência se reflete em sua natureza não objetiva. A ciência não é "pura neutralidade, mas a escolha de um caminho possível” (TRIGUEIRO, 2013, p. 26). Assim, o autor entende que a ciência não é isenta de valores e abrange aspectos sociais, políticos e individuais.

As atividades científicas, segundo Trigueiro (2012), não se relacionam apenas com normas e regras, embora se observe o ethos $^{12}$. Essas atividades dialogam com as

\footnotetext{
${ }^{12} \mathrm{O}$ ethos científico é o conjunto de normas e regras de conduta que são seguidas pelos membros de uma comunidade científica (TRIGUEIRO, 2012, p. 28).
} 
entidades científicas que são os constructos científicos como conceitos, leis e teorias. $\mathrm{O}$ autor explica que:

São desse modo, elementos constitutivos das atividades científicas, como as demais mencionadas. O que é característico da noção de entidade científica é que decorrem de construções conceituais visando a cumprir determinado propósito no processo investigativo e a integrar uma teoria (em última instância também uma entidade científica). (TRIGUEIRO, 2012, p. 28).

Trigueiro ainda propõe a ciência como uma práxis - um processo evolucionário constante -, que "se realiza mediante uma combinação dinâmica entre variação e seleção, dentro de um amplo conjunto" (TRIGUEIRO, 2012, p. 83). Complementa que essa perspectiva permite contemplar a ciência como um todo, desde os respectivos processos até os limites estruturais, como "algo aberto sem números de direções e trajetória".

O autor ainda critica Kuhn (2013) ao inferir que a ciência é mais que uma atualização de paradigmas. Trigueiro a entende como um campo aberto às realizações, que leva em consideração diversos ambientes, e complementa:

\footnotetext{
Em suma, a práxis científica consiste em permanente processo seletivo, em que algumas possibilidades científicas são escolhidas e realizadas, em detrimento de outras. Possibilidades, estas, que correspondem a um sem números de necessidades e interesses por novos conhecimentos provenientes da própria comunidade científica, ou de vários outros setores da Sociedade como demandas econômicas, políticas, culturais, médicas, alimentares, agropecuárias, educacionais e assim por diante. (TRIGUEIRO, 2012, p. 84).
}

Weber (2006) parece concordar com Trigueiro (2012) e complementa que a ciência tem as bases no mundo real e nas experiências dos cientistas, sejam elas puramente científicas, sejam empíricas. $\mathrm{O}$ uso da subjetividade na pesquisa científica, a qual o autor denomina como "objetividade" científica (WEBER, 2006), determina que a imparcialidade "pura" na pesquisa científica não se aplique ao campo das atividades científicas sociais. A subjetividade e o juízo de valor estão presentes em cada trabalho científico, seja na escolha do experimento (POPPER, 2013), seja na delimitação de um paradigma (KUHN, 2013).

Weber (2006) sustenta que as ciências sociais ocupam-se de eventos empíricos e observáveis, que despertam interesse investigativo. $\mathrm{O}$ cientista busca o aprofundamento dos fatos que lhe têm significação em seu respectivo mundo cultural. Ele acredita que a 
ciência não pode ser rígida, ela é flexível e adaptável e, portanto, imperativos não podem ser estabelecidos. Segundo o autor, "uma ciência empírica não tem como ensinar a ninguém sobre o que deve, somente sobre o que pode e, eventualmente, sobre o que quer" (WEBER, 2006, p. 17). Dessa forma, "não existe nenhuma análise científica puramente objetiva da vida cultural" (WEBER, 2006, p. 43).

Weber (2006) apresenta a significação e a ciência como posicionadas entre a realidade e o significado de realidade. Esse posicionamento, que o autor denomina "princípio da significação", auxilia-nos a compreender que, no "mundo" das ciências sociais, é possível obter diversos significados ou diversas visões para o mesmo objeto, sem a obrigatoriedade de aceitação de toda a comunidade científica, o que, mais uma vez, vai de encontro à proposta de Kuhn (2013).

Dessa forma, percebemos que as ideias de Weber (2006) são diferentes das de Popper (2013), ao entender que a validade científica não se pauta na lógica. Elas se contrapõem, principalmente no cerne da objetividade, pois, para Weber (2006), a "objetividade" científica se constrói a partir da relação entre o indivíduo, os significados e a realidade nos quais a pesquisa se insere. A realidade se relaciona com as questões históricas e, consequentemente, com as questões culturais nas quais a história está inserida.

Como forma de sintetizar a abordagem de cada autor em relação à "ciência" e à "objetividade científica", elaboramos dois quadros, que trazem, de forma resumida, nosso entendimento sobre as obras lidas. 


\begin{tabular}{|c|c|c|c|c|}
\hline & POPPER (2013) & KUHN (2013) & TRIGUEIRO (2012) & WEBER (2006) \\
\hline Origem & $\begin{array}{l}\text { Ciência a partir da } \\
\text { elaboração de teorias } \\
\text { experimentais } \\
\text { originadas ou não de } \\
\text { leis e } \\
\text { preexistentes. }\end{array}$ & $\begin{array}{l}\text { Ciência Normal a partir } \\
\text { de paradigmas } \\
\text { originados de uma } \\
\text { tradição científica e } \\
\text { aceitos por uma } \\
\text { comunidade científica. }\end{array}$ & $\begin{array}{l}\text { A Ciência origina-se das convenções } \\
\text { científicas, abertas e dinâmicas, } \\
\text { imbuídas de um ethos. } \\
\text { A Ciência alterna-se entre períodos } \\
\text { de estabilização e de crises. }\end{array}$ & $\begin{array}{l}\text { Ciência a partir de uma base } \\
\text { empírica de conhecimento } \\
\text { apoiada pelo significado que o } \\
\text { cientista confere a suas } \\
\text { realizações. }\end{array}$ \\
\hline Aplicação & $\begin{array}{l}\text { Aplica-se a enunciados } \\
\text { singulares } \\
\text { experimentos. }\end{array}$ & $\begin{array}{l}\text { Aplica-se a paradigmas } \\
\text { e a uma comunidade } \\
\text { científica específica. }\end{array}$ & $\begin{array}{l}\text { Aplica-se a uma ciência } \\
\text { evolucionária (práxis), que considera } \\
\text { todo o ambiente, assim como } \\
\text { diversas variáveis sociais do } \\
\text { ambiente. }\end{array}$ & $\begin{array}{l}\text { Aplica-se a todos os sujeitos } \\
\text { interessados em corroborar o } \\
\text { desenvolvimento da Ciência. }\end{array}$ \\
\hline $\begin{array}{l}\text { Perspectivas } \\
\text { da } \\
\text { objetividade }\end{array}$ & $\begin{array}{l}\text { Deve ser absoluta e } \\
\text { imparcial. }\end{array}$ & $\begin{array}{l}\text { Depende da aderência } \\
\text { dar comunidade } \\
\text { científica. Caso não haja } \\
\text { aderência, a pesquisa } \\
\text { não se desenvolve. }\end{array}$ & $\begin{array}{l}\text { Depende do ethos. Acontece em } \\
\text { decorrência de crises e evoluções } \\
\text { suportadas por aspectos políticos, } \\
\text { sociais, culturais e empíricos, que } \\
\text { lhe oportunizam o desenvolvimento } \\
\text { histórico-social. }\end{array}$ & $\begin{array}{l}\text { Não é absoluta. Toda pesquisa } \\
\text { científica se organiza com base } \\
\text { nos aspectos empíricos culturais e } \\
\text { sociais, sobretudo no contexto } \\
\text { histórico no qual a pesquisa se } \\
\text { insere. }\end{array}$ \\
\hline
\end{tabular}

Fonte: elaboração própria, com base nos autores estudados. 
Quadro 5 - Síntese da concepção de “objetividade” em Popper (2013), Kuhn (2013), Trigueiro (2012) e Weber (2006)

\begin{tabular}{|c|c|c|c|c|}
\hline & POPPER (2013) & KUHN (2013) & TRIGUEIRO (2012) & WEBER (2006) \\
\hline $\begin{array}{c}\text { Grau de } \\
\text { Flexibilidade }\end{array}$ & $\begin{array}{l}\text { A objetividade é } \\
\text { estrita e estática, } \\
\text { originada de } \\
\text { experimentos. }\end{array}$ & $\begin{array}{l}\text { A objetividade é } \\
\text { parcial, originada dos } \\
\text { paradigmas aceitos por } \\
\text { uma comunidade } \\
\text { científica. }\end{array}$ & $\begin{array}{l}\text { A objetividade não é "pura } \\
\text { neutralidade", podem-se escolher } \\
\text { os caminhos a percorrer. }\end{array}$ & $\begin{array}{l}\text { Ainda que busquemos a objetividade, } \\
\text { as percepções são predominantes, } \\
\text { sobretudo no entrecruzamento dos } \\
\text { saberes científicos. }\end{array}$ \\
\hline Aplicação & $\begin{array}{l}\text { Aplica-se a todas as } \\
\text { partes de uma } \\
\text { pesquisa científica. }\end{array}$ & $\begin{array}{l}\text { Aplica-se segundo os } \\
\text { critérios da comunidade } \\
\text { científica na análise do } \\
\text { paradigma. }\end{array}$ & $\begin{array}{l}\text { Aplica-se a uma comunidade ou } \\
\text { a outros setores da sociedade, } \\
\text { desde que respeitado o ethos das } \\
\text { descobertas científicas de } \\
\text { maneira dinâmica. }\end{array}$ & $\begin{array}{l}\text { A "objetividade" se aplica a todos os } \\
\text { aspectos da pesquisa. O juízo de valor } \\
\text { é presente e constante. Os significados } \\
\text { e a história têm estreita relação com a } \\
\text { objetividade. }\end{array}$ \\
\hline
\end{tabular}

Fonte: elaboração própria, com base nos autores estudados. 
Os entendimentos dos autores nos parecem ter, por vezes, sentidos conflitantes e, ao mesmo tempo, complementares, pois, por um lado, vislumbramos a validade científica puramente objetiva, lógica e experimental, e, por outro, observamos a validade dos paradigmas e dos traços de subjetividade em meio a uma tradição científica. De maneira alguma, buscamos demarcar conceitos estritos e estáticos, optando por uma abordagem ou por outra, pois "a estrada para um consenso estável na pesquisa é extraordinariamente árdua" (KUHN, 2013, p. 77). Concentramo-nos em delimitar uma base conceitual que possa ser apropriada para a Arquivologia e para a CI, na tentativa de responder às questões centrais desta pesquisa.

Entendemos que a base empírica e a objetividade, assim como o grau de aderência dos autores a esses dois conceitos, são polêmicos, mas fundamentais, enquanto lentes conceituais para a compreensão do nosso objeto de estudo. Sendo assim, a priori, consideraremos que o entendimento de ciência de Popper (2013) se aproxima da visão de Kuhn (2013), no sentido de que o conhecimento científico carece de um método para validá-lo, e o método é o ethos científico (TRIGUEIRO, 2012) das atividades científicas. Concordamos com Popper (2013) quanto à necessidade de compreendermos uma objetividade na pesquisa científica, sobretudo na condução dos métodos científicos. Entretanto, as subjetividades do cientista, combinadas com os aspectos culturais e históricos, devem ser consideradas no desenvolvimento da ciência (WEBER, 2006; TRIGUEIRO, 2012).

Desse modo, concordamos com Weber (2006) quanto à busca, pela ciência, de investigações que têm significado no respectivo mundo. Para esse autor, a objetividade se baseia "única e exclusivamente na ordenação da realidade dada segundo categorias que são subjetivas no sentido específico de representar o pressuposto de nosso conhecimento" (WEBER, 2006, p. 104).

A visão de paradigma e de tradição científica das comunidades científicas de Kuhn (2013) nos parece próxima da perspectiva de pesquisa tanto da Arquivologia quanto da CI, embora a rigidez da comunidade científica deva ser flexibilizada nesta pesquisa. Há de se considerar que as comunidades científicas podem dialogar entre si e, portanto, um paradigma pode perpassar ou ser complementado por outras disciplinas, embora ainda se tenha um ethos (TRIGUEIRO, 2012) que valida o conhecimento científico. Apreendemos que, como a ciência passa por constantes crises e revoluções, é um campo aberto, que se redescobre, evidenciando-se seu caráter dinâmico. Para a Arquivologia e a CI, percebemos uma 
necessidade de flexibilização quanto à definição de objetividade científica. Essa flexibilização pode ser representada pelo mapa conceitual abaixo:

Figura 1 - Graus de flexibilização da objetividade científica segundo Popper (2013), Kuhn (2013), Trigueiro (2012) e Weber (2006)

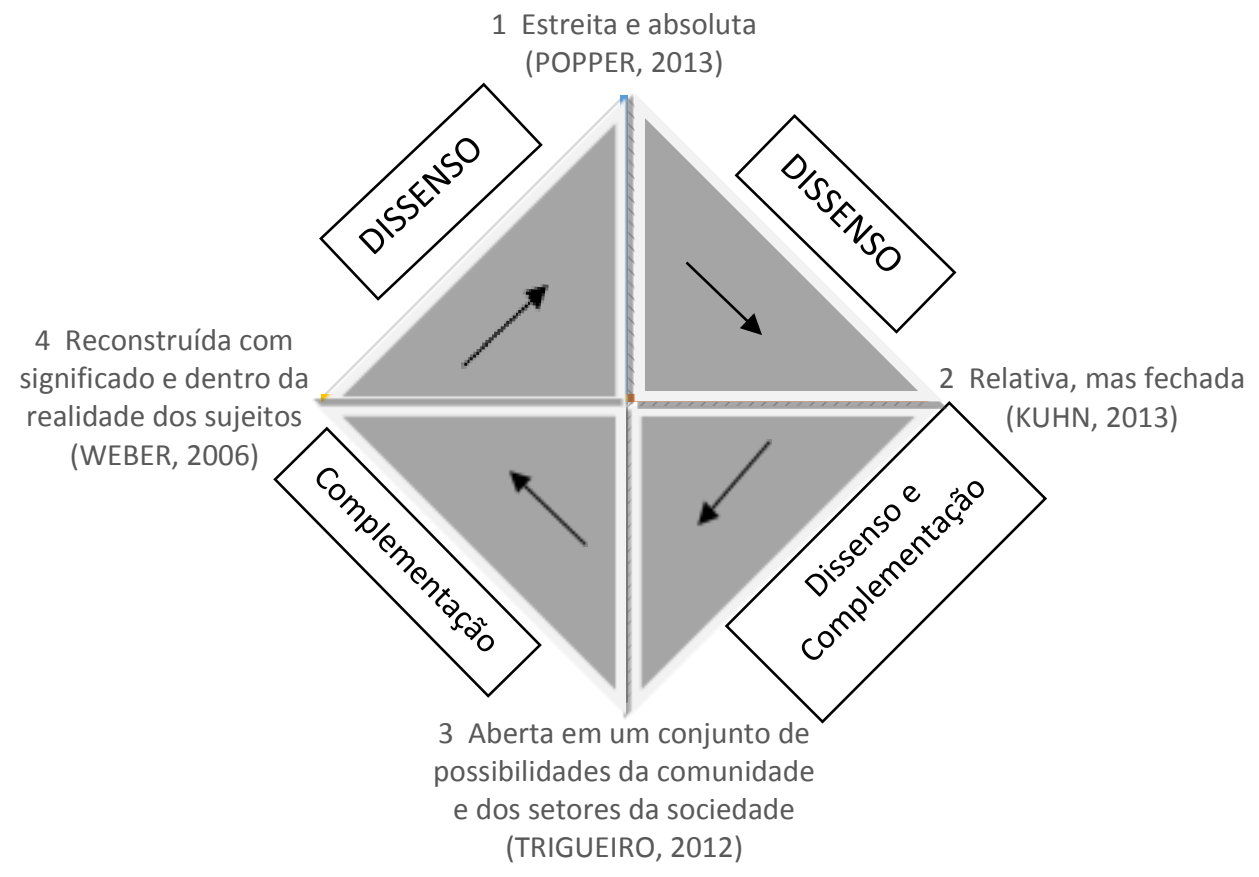

Fonte: elaboração própria, a partir da análise dos autores.

Notamos que a flexibilização se altera na medida em que os autores se afastam das Ciências Exatas e se aproximam das Ciências Sociais. Popper (2013) se opõe aos demais autores; Kuhn (2013), Trigueiro (2012) e Weber (2006) se complementam, em um movimento de relativização da objetividade, e trazem à tona as questões da construção subjetiva da base empírica, ainda que Trigueiro (2013) discorde de Kuhn (2012) quanto à definição de "paradigma". Weber (2006) se caracteriza, em nosso entendimento, como o autor mais flexível, tendo em vista a respectiva abordagem sociocultural da objetividade.

Popper (2013) tem raízes acadêmicas na Física, na Lógica e na Matemática, dessa forma, entendemos que a sua abordagem - objetividade estreita e absoluta - não se encaixa no universo empírico das Ciências Sociais. Todavia, os caminhos dos sistemas teóricos 
(conjecturas) do autor devem ser considerados como referenciais teóricos para a delimitação conceitual de "princípio científico".

Percebemos que a base empírica, nesta pesquisa, é elemento essencial de discussão, sobretudo do ponto de vista de Weber (2006). De fato, a ciência não pode ser tão estática a ponto de produzir normas e ideais obrigatórios, para deles se extraírem receitas para a prática (WEBER, 2006). Entendemos que a subjetividade e a objetividade relativa podem ser benéficas, auxiliando a ciência a superar crises e a se revolucionar, como propõem Kuhn (2013) e Trigueiro (2012). O juízo de valor não pode ser excluído das discussões científicas. Afinal, deve-se considerar que, por mais que os cientistas tendam a impor a objetividade aos seus trabalhos, os aspectos culturais e históricos da pesquisa dentro do contexto da comunidade científica (KUHN, 2013) se sobrepõem e não podem ser ignorados.

Ao propor o levantamento de um problema ou de um quebra-cabeça (KUHN, 2013), o sujeito atribui às respectivas discussões uma carga de conhecimento que lhe foi transmitida, bem como suas impressões e lentes teóricas. Dessa maneira, ainda que identifiquemos definições "fechadas" dos princípios arquivísticos e dos princípios da CI, estas não serão absolutas, uma vez que consideraremos que "a revolução científica" (KUHN, 2013) se pauta na fundação empírica (WEBER, 2006) traçada a partir de um conjunto composto de história, bagagem teórica e aspectos socioculturais absorvidos pelos autores.

A dinâmica da ciência, em constante redescobrimento, e do próprio cientista, nessa roda-gigante de transformações, traz-nos a reflexão de que as comunidades científicas e os paradigmas de Kuhn (2013) nos parecem um tanto quanto fechados, ao vislumbrarmos nosso objeto de pesquisa. Ainda que, no posfácio de sua obra, Kuhn (2013) tenha introduzido as matrizes curriculares, que acarretam justamente um viés de diálogo interdisciplinar, parecenos mais apropriado fazer um recorte conceitual, de maneira a adaptar esse diálogo ao escopo desta pesquisa.

Trigueiro (2012) redesenha o paradigma de Kuhn (2013), o que permite uma aplicação mais direta às Ciências Sociais. Percebe-se que sua proposta incentiva as articulações entre as disciplinas científicas e entre as comunidades científicas, o que parece atender aos intensos diálogos entre a Arquivologia e a CI, estabelecidos, sobretudo, nas relações que essas duas disciplinas guardam com a informação e os processos para a sua recuperação. Apesar de o entendimento ser bastante fechado, partimos da perspectiva de Kuhn (2013) para aplicá-la às Ciências Sociais. Propomos, a partir do estudioso, que a visão de paradigmas seja aplicada de maneira interdisciplinar, uma vez que, ao observarmos nosso objeto de estudo e as disciplinas 
que o envolvem, a interdisciplinaridade nos parece razoável e aplicável, no contexto do Campo da Informação.

Dessa maneira, propomos sintetizar as análises feitas, observando-se as contribuições dos autores para nossa pesquisa, assim como a aderência, ou seja, a aplicação dessas contribuições para os objetivos deste estudo, conforme quadro abaixo:

Quadro 6 - Contribuições, segundo Popper (2013), Kuhn (2013), Trigueiro (2012) e Weber (2006), para os objetivos desta pesquisa

\begin{tabular}{|c|l|l|}
\hline Autor & \multicolumn{1}{|c|}{ Contribuição para esta pesquisa } & $\begin{array}{c}\text { Aderência da contribuição para esta } \\
\text { pesquisa }\end{array}$ \\
\hline $\begin{array}{c}\text { POPPER } \\
\text { (2013) }\end{array}$ & $\begin{array}{l}\text { O método baliza a pesquisa e controla a } \\
\text { validade e a objetividade. }\end{array}$ & $\begin{array}{l}\text { Concorda-se com a necessidade de um } \\
\text { método científico, todavia a dedução não } \\
\text { dá conta da realidade da pesquisa social. }\end{array}$ \\
\hline KUHN (2013) & $\begin{array}{l}\text { Paradigma, matriz curricular e } \\
\text { comunidade científica. }\end{array}$ & $\begin{array}{l}\text { Propomos uma aplicação interdisciplinar } \\
\text { do paradigma. }\end{array}$ \\
\hline $\begin{array}{c}\text { TRIGUEIRO } \\
\text { (2012) }\end{array}$ & $\begin{array}{l}\text { O ethos científico se caracteriza por } \\
\text { regras e normas de uma comunidade } \\
\text { A verdade está presente na pesquisa } \\
\text { científica. } \\
\text { A ciência possui uma práxis. }\end{array}$ & $\begin{array}{l}\text { Concordamos que se deve ter um ethos, } \\
\text { embora, para as ciências sociais, esse } \\
\text { ethos se transforme constantemente, } \\
\text { justificando a práxis da Ciência. }\end{array}$ \\
\hline WEBER (2006) & $\begin{array}{l}\text { A pesquisa não está isenta de juízo de } \\
\text { valor. } \\
\text { História, realidade e significado têm } \\
\text { estreita relação. }\end{array}$ & $\begin{array}{l}\text { De fato, o cientista não se exime do juízo } \\
\text { de valor nas respectivas considerações } \\
\text { científicas, sobretudo por estar inserido } \\
\text { em uma realidade histórica e social. }\end{array}$ \\
\hline
\end{tabular}

Fonte: elaboração própria, com base nos autores estudados.

\subsection{Demarcação dos conceitos de "teoria" e "princípio científico"}

A “objetividade flexibilizada", percebida pela análise dos autores estudados, apontanos para a compreensão de que as definições de "teoria" e de "princípio científico" nos parecem ser influenciadas pela mencionada necessidade de flexibilização, representada na Figura 1. Tentaremos, assim, descrever as definições dos autores, representando-as segundo nossa compreensão.

Notamos, primeiramente, que seria necessário um entendimento prévio de alguns termos, de forma a identificá-los, ainda que implicitamente, tendo em vista o objeto de estudo desta pesquisa. Portanto, como ponto de partida conceitual, utilizaremos as definições apresentadas pelo Dicionário de Filosofia (ABBAGNANO, 2012), quais sejam:

a) Princípio - "ponto de partida e fundamento de um processo qualquer"; "O melhor ponto de partida, como, por exemplo, o que facilita aprender uma coisa"; "Ponto de 
partida efetivo de uma produção, como quilha de um navio ou os alicerces de uma casa" (ABBAGNANO, 2012, p. 928).

b) Teoria - "Especulação ou vida contemplativa"; "uma condição hipotética ideal, na qual tenham pleno cumprimento normas e regras que na realidade são observadas imperfeitas ou parciais"; "a chamada 'ciência pura', que não considera as aplicações da ciência técnica de produção, ou então as ciências, ou parte das ciências que consistem na elaboração conceitual ou matemática dos resultados, por exemplo, 'física teórica"”; "uma hipótese ou um conceito" (ABBAGNANO, 2012, p. 1122).

O método dedutivo orientado pela falseabilidade e verificabilidade acarreta, para nossa pesquisa, o apuro ao validar enunciados ou teorias: deve-se, até que se volvam irrefutáveis, tentar torná-los falsos, fazendo o movimento contrário ao praticado na maioria das pesquisas das Ciências Sociais (POPPER, 2013). Ou seja, os enunciados e as teorias são colocados à prova e sua falsidade é testada até que se tornem irrefutáveis, resultando em princípios ou leis. Pela nossa compreensão da abordagem de Popper (2013), entendemos que, em primeira instância, temos os princípios e as leis; em segunda instância, temos as teorias; e, em terceira, os enunciados. Segundo o estudioso, as teorias são conjuntos de enunciados e os princípios são postulados únicos e indiscutíveis, originados de enunciados e teorias, e são a base científica para o comportamento geral da Ciência. Ilustrativamente, temos:

Figura 2 - Visão de Popper (2013) sobre enunciados, teorias e princípios

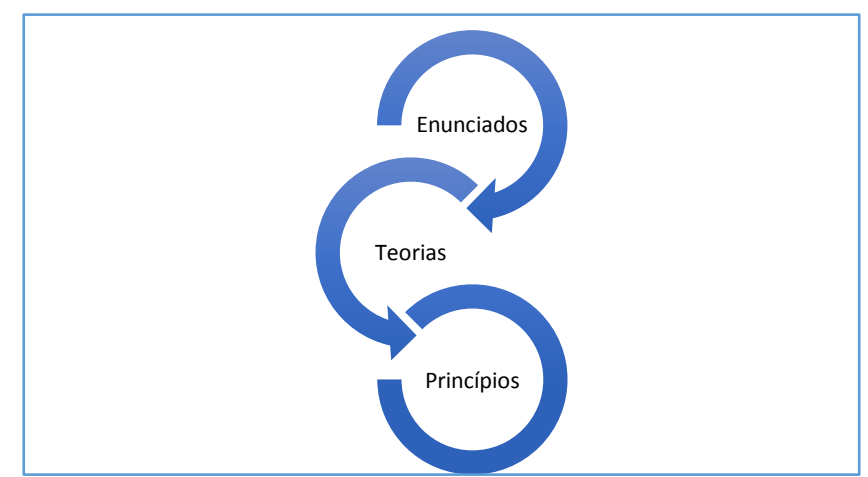

Fonte: elaboração própria a partir da análise de Popper (2013).

Para Kuhn (2013), a pesquisa científica está “dirigida para a articulação daqueles fenômenos e teorias fornecidos pelos paradigmas" (KUHN, 2013, p. 89). Segundo ele, a comunidade científica admite problemas (quebra-cabeças) na medida em que estes podem ser 
solucionados por um paradigma. Assim, os quebra-cabeças são expostos para as comunidades científicas e, quando aceitos, são admitidos como elementos a serem investigados e os cientistas são incentivados a estudá-los. Kuhn (2013) destaca que os quebra-cabeças se afastam dos problemas sociais, pois não podem "ser enunciados nos termos compatíveis com os instrumentos e conceitos proporcionados pelos paradigmas" (KUHN, 2013, p. 106). Dessa forma, o entendimento desse autor se afasta do de Weber (2006) e do de Trigueiro (2013), justificando as críticas feitas, principalmente por Trigueiro (2013), sobre a falta de dinamismo dos paradigmas e das comunidades científicas.

Compreendemos que as teorias são expostas para a comunidade científica como um possível quebra-cabeça, a partir do qual os cientistas são instigados a investigar a natureza do problema, embasando-se em paradigmas anteriores. Uma vez aceitas, as teorias são tidas como novos paradigmas, invalidando os paradigmas anteriores, que não são mais compatíveis com as demandas das novas descobertas. A estabilização das teorias como novos paradigmas "funciona como um mecanismo interno que assegura o relaxamento das restrições que limitam a pesquisa" (KUHN, 2013, p. 89).

Diante da comunidade científica, a admissão e a universalização desses novos paradigmas podem se desdobrar em princípios. O autor não apresenta uma definição para princípio científico, contudo apreendemos que os princípios podem advir de paradigmas que se tornam perenes, universalmente aceitos e estáveis dentro da comunidade científica. Esse movimento de validação e invalidação dos paradigmas e da construção de novas leis é geralmente cíclico, uma vez que Kuhn (2013) entende que a ciência se encontra em movimento e novos paradigmas são descobertos pela comunidade científica, o que desenvolve, assim, a tradição científica. Esse movimento, segundo o autor, é registrado pelos autores em manuais. Sendo assim, propomos a seguinte representação: 
Figura 3 - Visão de Kunh (2013) sobre a evolução da Ciência Normal

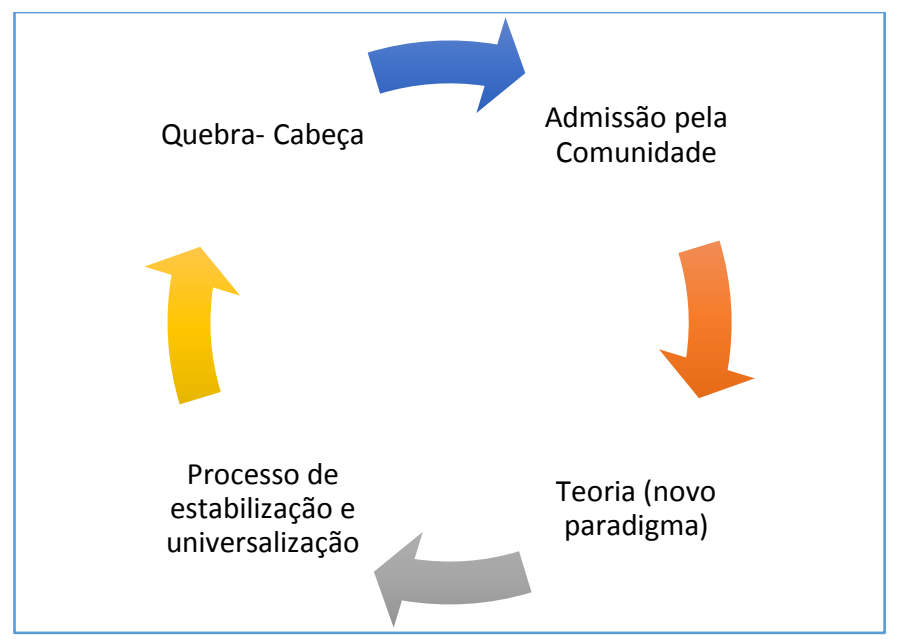

Fonte: elaboração própria a partir da análise de Kuhn (2013).

Trigueiro (2012), por sua vez, apresenta duas concepções para as teorias científicas: uma sintática e outra semântica. Pela sintática, o autor entende as teorias como um conjunto de axiomas 13 "logicamente articulados do ponto de vista de seus argumentos e deduções" (TRIGUEIRO, 2012, p. 35). Essa concepção se aproxima da perspectiva da lógica dedutiva de Popper (2013), no sentido da utilização da lógica para a comprovação das teorias. A concepção semântica se sustenta nos modelos que relacionam os axiomas às proposições e as outras entidades científicas ao mundo concreto. Essa percepção, segundo o autor, é mais adequada, uma vez que promove múltiplas possibilidades de interlocução das teorias com grandes áreas do conhecimento. São, dessa forma, relações “interteoréticas”. Nesse sentido, a visão de Trigueiro (2012) se aproxima da perspectiva de Weber (2006) quanto à multiplicidade do significado das teorias conforme seu contexto de interpretação.

Trigueiro (2012) acredita que as teorias são conjuntos de modelo ${ }^{14}$, melhores que os paradigmas (KUHN, 2013) e, em suas respectivas estruturas profundas, descrevem a realidade dizendo aquilo que ela realmente é. Desse modo, o autor entende que as teorias se compõem não apenas por entidades científicas (constructos teóricos), mas por técnicas (tecnologias), ou

\footnotetext{
${ }^{13}$ Segundo Trigueiro (2012, p. 35), "os axiomas ou os postulados são, a [sic] grosso modo, enunciados ou proposições não demonstradas, considerados como ponto de partida na formulação e aceitação de determinada teoria".

14 “".... o significado de modelo, nesse caso, não se limita ao de certas analogias físicas, a gráficos ou a figuras especiais, mas consiste em entidades abstratas, que guardam relação com um exterior, um 'lado de fora'. Nesse sentido mais preciso que se considera a noção de modelo no Estruturalismo metafísico" (TRIGUEIRO, 2012, p. 43).
} 
seja, por uma base empírica e pragmática que diz respeito à aplicação do conhecimento científico. O entendimento de "verdade", segundo o autor, leva-nos a entender que as discussões e reflexões científicas, assim como as teorias, não podem ser definitivas e consensuais, tampouco absolutas.

Os princípios científicos, na acepção de Trigueiro (2012, p. 42), dedicam-se a representar "alguns aspectos essenciais de uma parte da realidade empírica". Desse modo, podemos inferir que as teorias representam modelos que mesclam a realidade, o mundo concreto e os constructos teóricos. O conjunto dessas entidades científicas, enfim, configura os princípios, que, por sua vez, são "formulados de forma ampla” (TRIGUEIRO, 2012, p. 20), como representado na figura 4:

Figura 4 - Nossa interpretação da visão de Trigueiro (2012) sobre princípios científicos

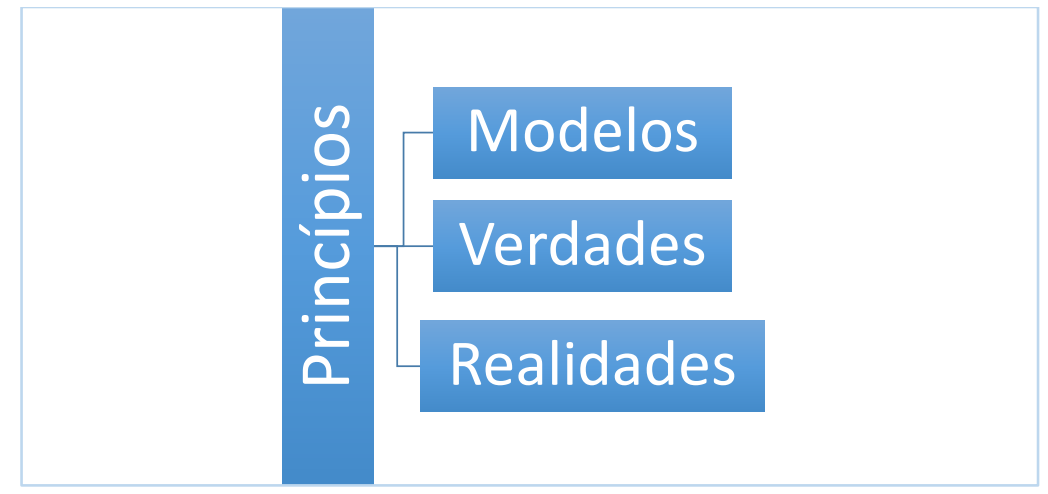

Fonte: elaboração própria a partir da análise de Trigueiro (2012).

Com o redesenho da "objetividade" científica, Weber (2006) propõe uma visão inovadora para as teorias científicas, uma teoria baseada em conhecimentos reflexivos da realidade, ou seja, de uma base empírica. Segundo o autor, a delimitação de teorias, ou o que ele chama de "conhecimento científico-social", não se deve deter em um significado singular, mas em uma "repetição regular de eventos" (WEBER, 2006, p. 48). O autor critica a tendência das ciências em delimitar "princípios" que solucionam os problemas práticos científicos, defendendo que cada indivíduo deve buscar o significado dos pressupostos e aplicá-los à sua realidade.

Por conseguinte, de acordo com Weber (2006), para as Ciências Sociais não há princípios definidos, uma vez que, por mais que esses conduzam a explicações práticas de "princípio", ou seja, como postulado inicial, "a criação de um denominador geral prático para nossos problemas de ideais últimos com validade geral certamente não pode ser parte de qualquer ciência empírica” (WEBER, 2006, p. 21). 
Destarte, ainda que o autor não delimite as definições para "princípio" e "teoria", apreendemos que os princípios científicos não poderiam ser, em sua abordagem, absolutos, uma vez que guardam fortes relações com a cultura e a realidade (significada diversamente) do indivíduo, bem como com os aspectos histórico-culturais da pesquisa. Assim, entendemos que os princípios se encontram em uma intersecção entre cultura, realidade e história. Compreendemos, também, que, para as Ciências Sociais, segundo Weber (2006), devemos focalizar mais na importância dos fenômenos e dos fatos históricos de acontecimentos científicos do que de teorias e leis absolutas. Assim, fizemos uma tentativa de representar a perspectiva de Weber (2006), conforme a figura 5 a seguir:

Figura 5 - Nossa interpretação da visão de Weber (2006) para princípio científico

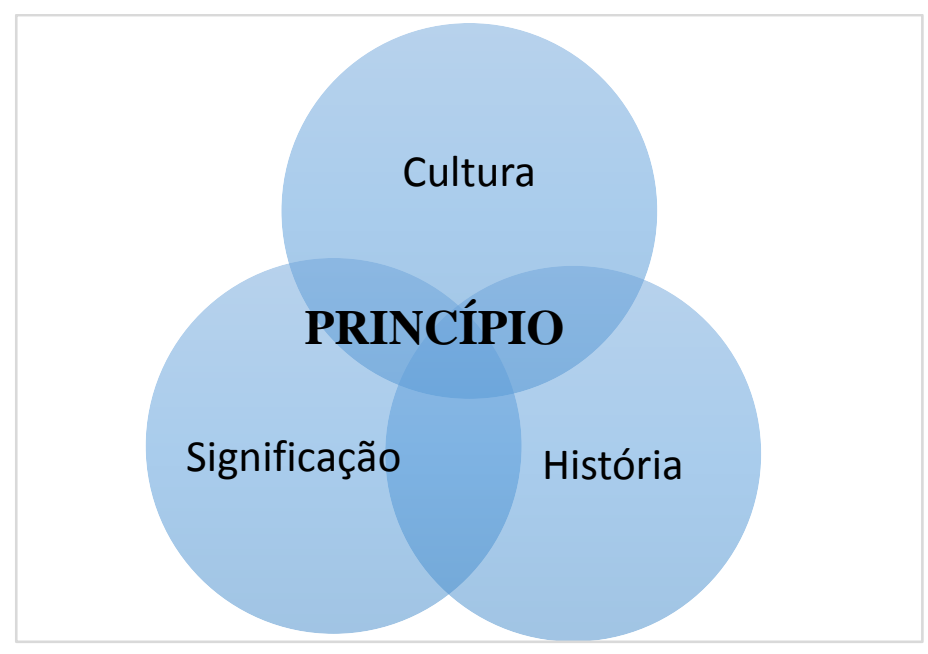

Fonte: elaboração própria a partir da análise de Weber (2006).

A partir da abordagem de cada autor sobre "teoria" e "princípio científico", apresentamos os seguintes quadros de definições, que sintetizam as propostas analisadas: 
Quadro 7 - Síntese da concepção de “teoria” em Popper (2013), Kuhn (2013), Trigueiro (2012) e Weber (2006)

\begin{tabular}{|c|c|c|c|c|}
\hline & POPPER (2013) & KUHN (2013) & TRIGUEIRO (2012) & WEBER (2006) \\
\hline \multicolumn{5}{|c|}{ TEORIA } \\
\hline $\begin{array}{l}\text { Origem/ } \\
\text { definição }\end{array}$ & $\begin{array}{l}\text { Conjunto de enunciados } \\
\text { colocados à prova, por meio } \\
\text { de experimentos científicos, } \\
\text { pelo método dedutivo. }\end{array}$ & $\begin{array}{l}\text { A teoria se desdobra em quebra- } \\
\text { cabeças. É a acumulação de } \\
\text { fatos definidos a partir de casos } \\
\text { e experiências. }\end{array}$ & $\begin{array}{l}\text { Resultante de uma prática científica, a } \\
\text { partir de um objeto de estudo. É um corpo } \\
\text { de saber explicitamente formulado de } \\
\text { determinado âmbito de realidade. }\end{array}$ & $\begin{array}{l}\text { Significação cultural de fatos históricos que } \\
\text { visa à troca de fenômenos de massa. No } \\
\text { caso das Ciências Sociais, a teoria é } \\
\text { elaborada pelos cientistas que lhe conferem } \\
\text { uma posição de sentido no mundo da } \\
\text { realidade. }\end{array}$ \\
\hline Aplicação & $\begin{array}{l}\text { As teorias, insumos para a } \\
\text { formulação de princípios, são } \\
\text { a base da ciência. Pela teoria, } \\
\text { fortalece-se a objetividade } \\
\text { científica. }\end{array}$ & $\begin{array}{l}\text { Para ser aceita como paradigma, } \\
\text { a teoria pode constituir-se de } \\
\text { conjuntos de conhecimentos } \\
\text { admitidos pela comunidade } \\
\text { científica. }\end{array}$ & $\begin{array}{l}\text { A teoria se compõe não apenas por } \\
\text { entidades científicas (constructos teóricos), } \\
\text { mas por técnicas (tecnologias), ou seja, } \\
\text { pela base empírica e a pragmática } \\
\text { aplicação dos conhecimentos científicos. }\end{array}$ & $\begin{array}{l}\text { A teoria oferece ao cientista a significação, } \\
\text { em seu mundo de realidade, dos } \\
\text { pressupostos científicos os quais despertam } \\
\text { o interesse de investigação. }\end{array}$ \\
\hline
\end{tabular}

Fonte: elaboração própria, com base nos autores estudados. 
Quadro 8 - Síntese da concepção de “ciência” em Popper (2013), Kuhn (2013), Trigueiro (2012) e Weber (2006)

\begin{tabular}{|c|c|c|c|c|}
\hline & POPPER (2013) & KUHN (2013) & TRIGUEIRO (2012) & WEBER (2006) \\
\hline \multicolumn{5}{|c|}{ PRINCÍPIO } \\
\hline Origem/Definição & $\begin{array}{l}\text { Coloca-se a teoria à prova, na } \\
\text { tentativa de torná-la falsa. Ao } \\
\text { perceber a sua irrefutabilidade, } \\
\text { encontra-se um princípio. }\end{array}$ & $\begin{array}{l}\text { Não apresenta definição. } \\
\text { Ao encontrar a estabilidade, o } \\
\text { paradigma torna-se a "lei" } \\
\text { vigente. }\end{array}$ & $\begin{array}{l}\text { O princípio é formulado de } \\
\text { forma ampla, propõe } \\
\text { representar aspectos } \\
\text { essenciais de uma realidade } \\
\text { empírica. }\end{array}$ & $\begin{array}{l}\text { Conteúdo de leis que são consideradas } \\
\text { cientificamente essenciais. O princípio é o } \\
\text { início das operações de condução ao } \\
\text { conhecimento. Conceito geral conforme a } \\
\text { significação cultural. }\end{array}$ \\
\hline Aplicação & $\begin{array}{l}\text { O princípio ou lei em vigor guia os } \\
\text { experimentos e as realizações } \\
\text { científicas. Novos experimentos } \\
\text { são feitos dentro de um } \\
\text { pressuposto advindo do princípio. }\end{array}$ & $\begin{array}{l}\text { O paradigma vigente como "lei" } \\
\text { se aplica imediatamente a toda } \\
\text { comunidade científica e a todos } \\
\text { os quebra-cabeças em estudo nas } \\
\text { investigações científicas. }\end{array}$ & $\begin{array}{l}\text { O princípio se aplica à } \\
\text { comunidade científica em } \\
\text { diferentes níveis de } \\
\text { agregação em um } \\
\text { movimento "interteórico". }\end{array}$ & $\begin{array}{l}\text { O princípio se aplica ao mundo real da } \\
\text { investigação científica, desde que consoante } \\
\text { aos aspectos culturais e históricos da } \\
\text { comunidade social no qual está inserido. Não } \\
\text { exclui outras comunidades, desde que tenha } \\
\text { sentido no seu mundo cultural. }\end{array}$ \\
\hline
\end{tabular}

Fonte: elaboração própria, com base nos autores estudados. 


\subsection{Apropriações da Filosofia e da Sociologia da Ciência no Campo da Informação}

Diante das contribuições da Filosofia e da Sociologia da Ciência e na demarcação das definições de "teoria" e "princípio científico", nos propomos a apropriá-las no Campo da Informação, sobretudo para a Arquivologia e para a CI, conforme a compreensão de Marques (2011) de Campo da Informação.

A autora propõe um Campo da Informação no qual a Arquivologia, a Documentação, a Biblioteconomia, a Museologia e a Ciência da Informação dialogam precipuamente no contexto da gênese, organização, recuperação e comunicação da informação ${ }^{15}$. Essa interlocução perpassa a construção de disciplinas científicas singulares, que têm suas respectivas crises, revoluções e evoluções, respeitando-se as especificidades de seus objetos de estudo.

\footnotetext{
É assim que acreditamos que as relações de parceria, cooperação e conflito vivenciadas por essas áreas decorrem do compartilhamento de um objeto comum - a informação -, perpassado por paradigmas comuns, diferenciados ao longo do tempo e que acabam por se desdobrar em relações (muitas vezes explicitadas em discursos) de hierarquização ou submissão, denunciadoras da sua luta por sobrevivência num campo tão competitivo. (MARQUES, 2011, p. 194).
}

Voltando-nos para os objetivos desta pesquisa, destacamos a posição da Arquivologia e da CI no Campo da Informação. Marques (2011) defende que a Arquivologia - embora persistentes tentativas de inseri-la como disciplina auxiliar da História, da Diplomática e até mesmo da CI - compõe esse campo, ocupando lugar único, com identidade própria, singular, perante uma comunidade científica em formação.

Assim como a Arquivologia, a CI também tem sua trajetória, embora sua origem apresente a interdisciplinaridade como característica potencial (MARQUES, 2011). Nessa perspectiva, Gomes (2001) destaca que a CI se assenta em uma região fronteiriça com as outras áreas do conhecimento, especialmente porque trabalha com problemas relacionados à informação. Entretanto, essa característica não dispensa a CI de delimitar seu "núcleo norteador de desenvolvimento das pesquisas no seu interior" (GOMES, 2001, p. 3).

\footnotetext{
15 Aqui utilizamos o termo informação em sentido lato, tendo cada disciplina científica sua perspectiva de informação. Por exemplo, a Arquivologia trabalha com a informação orgânica registrada, segundo Tognoli (2010) e Marques (2011).
} 
A visão de Gomes (2001), em nosso entendimento, é corroborada no Campo da Informação de Marques (2011) e nos auxilia a perceber que, nesse campo, em especial na Arquivologia e na CI, delimita-se o ethos científico a partir dos objetos de estudo das disciplinas científicas, uma vez que os objetos são elementos diferenciadores nesse Campo, bem como seus princípios.

Aplicando-se as contribuições de Kuhn (2013) tanto na Arquivologia quanto na CI, os paradigmas dialogam entre si e por entre as disciplinas do Campo da Informação, cenário da nossa macrocomunidade científica. Novos paradigmas são postos em discussão, tendo-se em vista as mudanças históricas e socioculturais e a necessidade das duas disciplinas científicas, em constantes movimentos no cenário científico, como postulam Weber (2006) e Trigueiro (2012). A afirmação de Marques (2011) confirma nossa reflexão, pois a autora aponta como paradigmas da Arquivologia, ao longo da trajetória de formação como disciplina científica:

Foco inicial na organização e preservação física de documentos, tendo em vista a manutenção da memória; preocupação com o arquivo como instituição de guarda de documentos; preocupação com o aperfeiçoamento e compartilhamento de técnicas voltadas para a organização e disponibilização de documentos; preocupações recentes com seu desenvolvimento como disciplina científica e seus desdobramentos: formação profissional, produção de pesquisas, criação de cursos de graduação e pós-graduação, etc. (MARQUES, 2011, p. 194).

Para a CI, a mesma autora apresenta como paradigmas, também ao longo da sua histórica trajetória de formação disciplinar:

\footnotetext{
Volta-se para os processos que abarcam os movimentos da informação em um sistema de comunicação humana, abrigando os interesses da Documentação e indo ao encontro daqueles das demais disciplinas do campo da informação; preocupações com a recuperação da informação conforme as demandas dos usuários; busca da compreensão da informação em si mesma, inicialmente numa aproximação matemática e, mais recentemente, de acordo com o contexto social; produção de pesquisas, contemplando, inclusive, temáticas de outras disciplinas que lhe são próximas. (MARQUES, 2011, p. 195).
}

Podemos observar a proximidade dos paradigmas que perpassam as duas disciplinas, confirmando nossa percepção de paradigmas comuns. A Arquivologia e a CI guardam relações próximas entre si e com a Biblioteconomia e a Museologia, sobretudo se voltando “para a preservação da memória, centrados no papel desempenhado por instituições legitimadas para tal: os arquivos, as bibliotecas e os museus" (MARQUES, 2011, p. 195).

As discussões científicas, por sua vez, originadas das tentativas de estabilizar os paradigmas comuns, são portadoras de práxis (TRIGUEIRO, 2012) e objetivam validar os 
novos conhecimentos científicos. Esse ciclo de "crise" e "revolução" (KUHN, 2013; TRIGUEIRO, 2012) da Arquivologia e da CI as eleva a novos patamares de conhecimento e, por vezes, reformula as respectivas teorias e princípios, confirmando o movimento evolutivo de ambas as disciplinas científicas, tanto nos aspectos práticos quanto nos técnicos e teóricos.

Aplicando as contribuições de Popper (2013) à nossa pesquisa, inferimos que os entrecruzamentos a serem realizados nas etapas metodológicas nos levarão a teorias (conjecturas) comparadas, segundo o Método da História Cruzada (WERNER; ZIMMERMANN, 2003), até que se atinja a um consenso majoritário. Não podemos buscar a irrefutabilidade, assim como nas Ciências Exatas, como postula Popper (2013), uma vez que não podemos nos eximir de que a Arquivologia e a CI trabalham predominantemente com a base empírica tão criticada por Popper (2013), parcialmente amparada por Kuhn (2013) e amplamente apoiada por Weber (2006).

Da mesma forma, não podemos nos apropriar inteiramente da abordagem de Weber (2006), pois, assim como Schmidt (2012), Tognoli (2010) e Marques (2011), acreditamos que a Arquivologia começou a se formar como disciplina científica a partir da publicação de manuais e da promulgação dos princípios arquivísticos. Portanto, essa disciplina científica necessita de princípios científicos balizadores dos respectivos métodos e técnicas. Entendemos que isso também se aplica à CI e que devemos buscar os princípios científicos que poderão posicioná-la como disciplina com identidade própria, como nos proporemos a apresentar no capítulo 4.

Levando em conta as apropriações conceituais utilizadas, sintetizamo-las no quadro 9 abaixo:

Quadro 9 - Aplicação das apropriações conceituais no Campo da Informação

\begin{tabular}{|c|l|}
\hline AUTOR & \multicolumn{1}{c|}{ Apropriação no Campo da informação } \\
\hline POPPER (2013) & Consenso majoritário nas demarcações conceituais em vez da irrefutabilidade. \\
\hline KUHN (2013) & $\begin{array}{l}\text { Paradigma utilizado por uma macrocomunidade científica e não apenas por uma única } \\
\text { comunidade. }\end{array}$ \\
\hline $\begin{array}{c}\text { TRIGUEIRO } \\
\text { (2012) }\end{array}$ & $\begin{array}{l}\text { Objeto de estudos da Arquivologia e da CI como ethos científico. Práxis e diálogos dos } \\
\text { paradigmas. }\end{array}$ \\
\hline WEBER (2006) & Inserção da realidade, história e significação nas demarcações conceituais. \\
\hline \multicolumn{2}{|l}{ Fonte: elaboração própria, como base nos autores estudados. }
\end{tabular}


Assim, considerando-se as contribuições de Marques (2011) sobre o Campo da Informação, as apontadas por Kuhn (2013), Popper (2013), Trigueiro (2012) e Weber (2006) na seção anterior e as reflexões feitas nesta seção, propomos como:

- Princípio científico: postulado consensual que, advindo de enunciados e teorias que relatam a realidade empírica de uma disciplina, no caso da Arquivologia e da CI, torna-se base teórica para o funcionamento, amadurecimento e consolidação científica mediante a sua assimilação e validação por cima da comunidade científica (Campo da Informação);

- Teoria: conjunto de enunciados científicos formulados a partir de crises das disciplinas científicas, em obediência ao ethos científico, dentro de uma realidade e de necessidades científicas e situado em um contexto histórico-cultural;

- Método: maneira pela qual se organiza a verificação dos enunciados e das teorias, a partir dos princípios científicos;

- Técnica: aplicação do método, tendo em vista a práxis e o ethos das disciplinas científicas. 


\section{PRINCÍPIOS ARQUIVÍSTICOS E SUAS CONTRIBUIÇÕES PARA A ARQUIVOLOGIA}

"Como afirmam as definições, os documentos de arquivo, ou melhor, as informações orgânicas, têm natureza própria que não depende do suporte nem da forma, nem da escrita ou da antiguidade. Tal natureza é consubstancial a essa informação, fora de toda contingência, acontecimento ou acidente. No instante em que foi criada ou recebida por um organismo ou por uma pessoa no decorrer de sua atividade, uma informação, por isso mesmo, é uma informação de arquivo e faz parte do fundo de arquivo do seu autor ou do seu destinatário, tanto quanto os documentos mais antigos." (DELMAS, 2010, p. 132).

A Arquivologia teve suas origens marcadas, após a criação do primeiro Archives Nationales de France, em 1794, e depois da 2a Guerra Mundial, pelos anseios de informação dos cidadãos, tornando-a acessível. Como disciplina, vem-se desenvolvendo desde, aproximadamente, o século XVII, segundo Fonseca (2005), tendo como marco a edição do Manual de Arranjo e Descrição, de 1898, de Muller, Feith e Fruin (1960), como lembram Tognoli (2010), Marques (2011) e Schmidt (2012).

Os princípios arquivísticos contribuem para a tradição arquivística, delimitando o respectivo objeto de estudo - a informação orgânica registrada - e contribuindo para a atuação ativa da disciplina nos programas de graduação e pós-graduação (TOGNOLI, 2010; MARQUES, 2011; SCHMIDT, 2012). Dentre os diversos princípios, como os princípios de respeito à ordem original, respeito aos fundos, territorialidade, reversibilidade, pertinência e pertinência territorial, elencados no Dicionário Brasileiro de Terminologia Arquivística (ARQUIVO NACIONAL, 2005), tomamos como objeto central deste capítulo:

Princípio da proveniência - Princípio básico da Arquivologia segundo o qual o arquivo produzido por uma entidade coletiva, pessoa ou família não deve ser misturado aos de outras entidades produtoras. Também chamado princípio do respeito aos fundos. (ARQUIVO NACIONAL, 2005, p. 136).

Cabe ressaltar que, inicialmente, consideramos como princípio arquivístico apenas o Princípio da Proveniência. Após pesquisa realizada no âmbito do PROIC da UnB, entre junho de 2011 e agosto de 2012, conforme mencionamos na Introdução desta dissertação, inferimos que esse princípio é majoritariamente aceito como base científica para a existência da 
Arquivologia enquanto disciplina autônoma. Consideramos, também, que o respeito aos fundos ${ }^{16}$ se refere à aplicação do Princípio da Proveniência.

Dentre os princípios "secundários" ou desdobrados da proveniência, elencamos:

Princípio do Respeito à Ordem Original - Princípio segundo o qual o arquivo deveria conservar o arranjo dado pela entidade coletiva, pessoa ou família que o produziu. (ARQUIVO NACIONAL, 2005, p. 140).

Proveniência territorial (Princípio da Territorialidade) - Conceito derivado do princípio da proveniência segundo o qual arquivos deveriam ser conservados em serviços de arquivo do território no qual foram produzidos, excetuados os documentos elaborados pelas representações diplomáticas ou resultantes de operações militares. (ARQUIVO NACIONAL, 2005, p. 140).

Não consideramos como princípios arquivísticos os "princípios" da reversibilidade e da pertinência (ARQUIVO NACIONAL, 2005), uma vez que, ao longo da pesquisa realizada no escopo da iniciação científica, entendemos que esses não foram apresentados na maioria dos manuais estudados, tampouco são tidos como "consensos majoritários". Ademais, esses princípios parecem contradizer ou, pelo menos, desviar-se do Princípio da Proveniência, o qual entendemos ser ponto central de discussão do capítulo.

Destacamos também, para o entendimento das discussões deste capítulo, a definição de “organicidade". Segundo o Arquivo Nacional (2005):

Organicidade - relação natural entre os documentos de um arquivo em decorrência das atividades da entidade produtora. (ARQUIVO NACIONAL, 2005, p. 127).

Bellotto (2006) entende que, a partir de 1841, quando houve o registro da Teoria dos Fundos, a partir das circulares e dos regulamentos publicados na França, a qualidade orgânica ou a organicidade, como tomamos para a pesquisa, transpõe as "relações significativas" do documento. A organicidade deve, assim, ser entendida como a qualidade segundo a qual os arquivos refletem a estrutura, as funções e as atividades da entidade (BELLOTTO, 2006). A autora complementa que a qualidade orgânica é o pilar dos fundos, das séries e dos documentos e respeita a naturalidade, a unicidades e a proveniência de sua criação.

Numa perspectiva próxima à de Bellotto, Duranti (1997), por meio do termo "archival bond", preconiza que o documento somente se torna um documento arquivístico quando se relaciona com sua existência administrativa sua proveniência, as razões pelas quais foi criado,

\footnotetext{
${ }^{16}$ Existem autores que consideram o respeito aos fundos como princípio essencial, e outros o entendem como um dos graus da Proveniência.
} 
bem como o contexto de sua produção. Ainda segundo a autora, o archival bonds direciona a “causa e o efeito" (DURANTI, 1997, p. 217, tradução nossa) dos documentos nas instituições às quais pertencem. O termo proposto por Duranti (1997), em nosso entendimento, pode ser uma tradução da organicidade, tal como Bellotto (2006) definiu. Para esta pesquisa, compreendemos como "organicidade" as relações orgânicas que os documentos guardam com seu produtor/acumulador e entre si, considerando-se as razões de produção/acumulação, bem como sua proveniência e as "causas e efeitos" da sua existência.

Sendo assim, neste capítulo, as discussões foram dispostas em três partes: 1) a visão tradicional do Princípio da Proveniência; 2) o redescobrimento do Princípio da Proveniência; e 3) as contribuições e repercussões do Princípio da Proveniência. Na primeira parte, propomos apresentar o mapeamento desse princípio arquivístico nos manuais internacionais e nacionais da área, identificados por Marques (2011), segundo a visão tradicional. A análise contemplará os marcos históricos, as contribuições e a importância do Princípio da Proveniência na trajetória da Arquivologia. Na segunda parte, procuramos obras e autores que apresentem novas abordagens para o Princípio da Proveniência, redescobrindo-o e propondo novas aplicações. Na terceira parte, apresentamos a análise dos resultados obtidos.

A diversidade das visões dos autores a serem analisados nos subsidiará no estudo sequencial dos manuais, a fim de compreender as origens, definições, aplicações e repercussões, na identificação dos sensos e dissensos apresentados, acerca do objeto de estudo. Procuramos, igualmente, entender o princípio no desenvolvimento teórico e epistemológico da própria Arquivologia, buscando destacar os marcos históricos e conceituais do Princípio da Proveniência na trajetória dessa disciplina.

\subsection{O Princípio da Proveniência e seus desdobramentos}

Apresentamos o mapeamento do Princípio da Proveniência em 38 manuais internacionais e 11 nacionais da área, segundo a visão tradicional, conforme referências bibliográficas ${ }^{17}$ e quadros 1 e 2 . O estudo do mencionado princípio realizou-se a partir do

\footnotetext{
${ }^{17}$ Alguns autores como Vázquez (1995), Jardim (1995; 1998), Paes (1998), Gallego Domingues e Lopes Gomez (1989) não foram considerados para essa análise, uma vez que não apresentaram o princípio quanto aos aspectos estudados. Não foram consideradas as coletâneas, pois, segundo Kuhn (2013), os manuais registram a evolução de uma disciplina. De acordo com o autor, os manuais são os principais registros da evolução da Ciência Normal. Ele preconiza que os pesquisadores iniciam seus estudos a partir dos manuais, que contêm os paradigmas vigentes e em discussão na comunidade científica.
} 
Manual dos Arquivistas Holandeses, de 1898 (MULLER; FEITH; FRUIN, 1960), de acordo com o Método da História Cruzada (WERNER; ZIMMERMANN, 2003).

A análise se dá por meio de leituras sequenciais e sintetizadas em quadros de análise que preveem os marcos históricos, as definições e as repercussões, bem como a importância e as contribuições desse princípio para a Arquivologia. Nesse contexto e diante das diversas abordagens dadas pelos autores, buscamos sistematizar a discussão em torno de eixos de análise, concentrando as definições dos autores quanto: a) à identidade e aos desdobramentos do Princípio da Proveniência em relação aos demais princípios, especialmente o Respeito aos Fundos; b) à (in)dependência dos demais "princípios" em relação ao Princípio da Proveniência; c) à origem institucional dos autores (conforme os países aos quais estejam vinculados profissionalmente). Os eixos propostos não são excludentes e se complementam com o objetivo de relacionar os autores e as diversas denominações e visões dadas ao princípio em estudo.

\subsubsection{Marcos históricos e definições do Princípio da Proveniência: contribuições e repercussões para a trajetória da Arquivologia pela visão tradicional}

O Princípio da Proveniência teve suas origens demarcadas em diferentes locais e datas. Na França, por exemplo, no século XVIII, utilizavam-se métodos de arranjo temáticos, isto é, baseados nos assuntos dos documentos. Os aspectos temáticos perpassavam as fases de tratamento da informação desde o sistema de registros (protocolo). Após a Revolução Francesa e em razão dos inúmeros problemas gerados por esse método quanto à identificação e recuperação dos documentos, reconheceu-se a necessidade de: 1) organizar os arquivos se concentrando no respectivo acesso pelo público; e 2) responsabilizar o Estado pela conservação e pelo tratamento dos documentos (SCHELLENBERG, 2006).

Após a criação do Arquivo Nacional da França, seguida da edição da circular e de um regulamento voltado para o arranjo de documentos, desenvolveu-se uma nova metodologia de organização, baseada no agrupamento lógico do arranjo, por fundos. De acordo com Schellenberg (2006), em seu manual publicado em 1956, Guizot ${ }^{18}$ foi o autor do regulamento, em 1839, que destacava o agrupamento lógico de documentos, obedecendo à sua origem de produção. Esse regulamento foi complementado pela circular de 24 de abril de 1841, editada por Natalis de Wailly, chefe da seção administrativa dos arquivos departamentais do

18 Ministro da Instrução Pública, de 1832 a 1839, e primeiro-ministro, de 1840 a 1848, na França (SCHELLEBERG, 2006, p. 241). 
Ministério do Interior. Tratava-se de instruções para se colocar em ordem e classificar os arquivos departamentais e comunais (SCHELLENBERG, 2006). Esse autor lembra que, em 8 de julho de 1841, Wailly ratificou a circular destacando o respeito aos fundos como o princípio básico, também conhecido como Princípio da Proveniência. ${ }^{19}$ Heredia Herrera (1991), em 1982, e Duchein (1986) ${ }^{20}$ afirmam que a circular de Natalis de Wailly (1841) foi elaborada na mesma data em que Guizot teria publicado o documento, de acordo com Schellenberg (1980).

Rosseau e Couture (1998), em 1994, Cruz Mundet (2001), em 1994, e Ruiz Rodrigues (2008), em 1995, complementam essa afirmação de Heredia Herrera (1991) ao defenderem que Natalis de Wailly anunciou, por meio da circular, o marco teórico fundamental para a Arquivologia, definindo-a, a partir daí, como disciplina científica. Bellotto (2006), em 1991, e Martín-Pozuelo Campillos (1996), por sua vez, discordam dessa concepção e mencionam que Guizot homologou sua instrução primeiramente, em 1839, e Wailly teria apenas a complementado, em 1841.

O pioneirismo francês pode ter influenciado o desenvolvimento do pensamento arquivístico de vários países, incluindo a Arquivologia brasileira. No entanto, podemos observar que não há consenso entre os autores estudados quanto à data e à autoria do documento que anuncia o Princípio da Proveniência na França. Mesmo assim, diversos estudiosos se basearam no modelo francês, repercutido a partir daquele documento e o qual exalta o respeito aos fundos, como unidades indivisíveis.

$\mathrm{Na}$ Itália, entre o final do século XVII e início do século XIX, o método de ordenamento por matéria (assunto) também era utilizado. Carucci (2010), em 1983, lembra o pensamento da época, voltado para os documentos como grandes livros de História, que permaneciam inacessíveis e cuja classificação se baseava no assunto. Após a Revolução Francesa, essa metodologia começou a ser questionada e, consequentemente, perdeu força, e o metodo storico se espalhou pelo país. Observamos que a mudança de um método para outro aconteceu de forma gradativa, conforme descreve a autora.

\footnotetext{
${ }^{19}$ Como veremos, há autores que consideram o Respeito aos Fundos um princípio arquivístico e outros que o entendem como um dos graus do Princípio da Proveniência. Neste artigo, consideraremos que o respeito aos fundos se refere à aplicação do Princípio da Proveniência e, portanto, é um desdobramento desse princípio na demarcação externa dos fundos, conforme a sua proveniência.

${ }^{20} \mathrm{O}$ artigo de Michel Duchein "O respeito aos fundos em arquivística: princípios teóricos e problemas práticos" (1986) não foi contemplado, inicialmente, em nosso rol de obras internacionais analisadas, que excluiu artigos. Todavia, consideramos a sua importância teórica e o incluímos na nossa análise, como bibliografia complementar.
} 
Segundo Heredia Herrera (1991) e Lodolini $(1993)^{21}$, Francesco Bonaini ${ }^{22}$ definiu o princípio de ordenação original dos arquivos por meio do metodo storico. Em 23 de março de 1867, esse italiano publicou uma circular no Ministério da Instrução Pública, na qual expressava sua contribuição à formação teórica italiana e às políticas públicas (LODOLINI, 1993). O metodo storico é, então, instituído como marco histórico na Itália (BRENNEKE, 1968; SCHELlENBERG, 2006; TAMBLÉ, 1993; CARUCCI, 2010) ${ }^{23}$, influenciando, diretamente, o desenvolvimento do Princípio da Proveniência naquele país.

Nos Países Baixos, o Princípio da Proveniência, segundo Schellenberg (2006), foi oficialmente sancionado em 10 de julho de 1897, pelo Ministro do Interior, embora o mesmo autor mencione que, em 1881, na Prússia, fora anunciado um regulamento que dispunha sobre alguns princípios da área, dentre eles o Registraturprinzip, o qual ressalta a importância da ordem dada aos documentos pelos serviços de registro de documentos.

A ocasião inspirou os holandeses na elaboração do manual que passaria a ser considerado o marco teórico para o desenvolvimento da Arquivologia como disciplina (MULLER; FEITH; FRUIN, 1960). O Manual de Arranjo e Descrição foi escrito por Samuel Muller $^{24}$, Johan A. Feith ${ }^{25}$ e Robert Fruin ${ }^{26}$, com o nome original de Handleiding voor het Ordenen em Beschrijven van Archieven. O manual concentrou as principais práticas arquivísticas holandesas do século XIX, objetivando, sobretudo, a padronização dessas práticas em todo o país (RIDENER, 2009).

No continente americano, Schellenberg (1980), Bellotto (2006) e Berner (1983) mencionam que o arquivista e historiador Waldo G. Leland ${ }^{27}$ elaborou um projeto de organização dos arquivos estaduais norte-americanos em 1904, com base no respeito aos

\footnotetext{
${ }^{21} \mathrm{O}$ manual desse autor foi publicado em 1984.

${ }^{22}$ Considerado o pai da Arquivologia italiana, o historiador e arquivista Francesco Bonaini estabeleceu a base do Princípio da Proveniência pelo método histórico na Itália. Bonaini foi responsável pelo início do estudo de várias disciplinas próximas da Arquivologia, como a Diplomática e a Paleografia. O autor dedicou-se também à teoria da Biblioteconomia (LODOLINI, 1993).

${ }^{23}$ Os manuais desses autores foi publicado em 1953, 1956, 1993 e 1983, respectivamente.

24 Arquivista do Arquivo Nacional Holandês, especialista em tratamento de documentos governamentais, contribuiu com as questões de 1000 a 1300 do Manual. Muller especializou-se, posteriormente à publicação do manual e até 1922, no estudo da Diplomática e da Paleografia, com foco na autenticidade dos documentos (RIDENER, 2009).

25 Arquivista do Arquivo Estadual de Groningen, elaborou as questões de 26 a 99 do referido Manual (RIDENER, 2009). Segundo o autor, Feith recebeu muitas críticas, devido ao seu estilo de texto peculiar.

${ }^{26}$ Arquivista do Arquivo Estadual de Zeeland. Antes da coautoria no Manual Holandês, elaborou um manual para o Arquivo Nacional do Governo Holandês. Ele publicou outro manual sobre a legislação arquivística holandesa, contribuindo ricamente para o desenvolvimento da teoria à época (RIDENER, 2009).

${ }^{27}$ Waldo Gifford Leland, nascido em 17 de julho de 1879, historiador americano, contribuiu relevantemente para o desenvolvimento da Arquivologia nos Estados Unidos. Ele publicou, em 1904, o Guide to the Archives of the Government of the United States in Washington. Após essa publicação, fomentou a criação do Arquivo Nacional americano, juntamente com seu orientador, J. Franklin Jameson (BERNER, 1983).
} 
fundos. Leland apresentou os princípios de classificação em uma conferência, mas suas afirmações repercutiram após a publicação de seu artigo, em 1912 (BERNER, 1983).

O manual de Hillary Jenkinson (1965), publicado em 1922, também introduziu, na teoria americana, a ideia de relações orgânicas e naturais intactas, seguida de Schellenberg (1980), em 1956, que foi um marco na Arquivologia ao editar, em suas obras, os valores documentais em sintonia com o Princípio da Proveniência.

No Canadá e na Austrália, a teoria arquivística sofreu também grande influência desses dois estudiosos. Os records groups $^{28}$ daqueles países assemelham-se aos fonds franceses (LOPES, 1996, p. 76). Schellenberg (1980) insere o respeito aos fundos e o respeito à ordem original no contexto da proveniência, embora não tenhamos identificado, nos manuais, documentos, tal como o regulamento francês, que tenham marcado as origens do Princípio da Proveniência nesses países.

No que tange à definição do Princípio da Proveniência, percebemos que ela foi delimitada a partir de diversas abordagens desde os franceses e vem sendo ratificada e remodelada até os dias de hoje. Sendo assim, apresentamos algumas dessas definições que foram elaboradas pelos autores estudados, segundo suas origens institucionais.

Muller, Feith e Fruin (1960) foram precursores na delimitação do respeito aos fundos e da ordem original, fomentando a ideia de relação orgânica do documento com a sua entidade produtora, o que aponta para a relação do respeito aos fundos com o Princípio da Proveniência Os autores entendem por respeito aos fundos a organização documental que, em sua essência, respeite a organização administrativa da instituição que produziu os documentos. Assim, afirmam que o (re)estabelecimento da ordem primitiva é regra fundamental, da qual derivam as demais normas.

Jenkinson (1965) e Brenneke (1968) concordam com os holandeses quanto à utilização das relações orgânicas para se reestabelecer a relação administrativa com a produção/acumulação documental. Entretanto, Brenneke (1968), com manual publicado em 1953, assim como Schellenberg (1980), mescla as definições de respeito aos fundos, ordem original e Princípio da Proveniência, ressaltando a importância desse Princípio na organização dos arquivos, em especial dos arquivos históricos.

\footnotetext{
${ }^{28}$ Os records groups são conjuntos de documentos dispostos em divisões hierárquicas baseadas na proveniência. Essas divisões representam as relações administrativas das instituições. A depender do tamanho do acervo, os groups podem ser subdivididos em subgrupos e séries (SOCIETY OF AMERICAN ARCHIVIST, 2015). Disponível em: <http://www2.archivists.org/glossary/terms/r/record-group>. Acesso em: 3 mar. 2015.
} 
O Registraturprinzip (Registry Principle), enunciado na Prússia, também determina que os documentos devam ser classificados desde a sua produção (CRUZ MUNDET, 2001), considerando-se as séries documentais primeiramente como registros administrativos, nos quais se reflete a estrutura administrativa (BERNER, 1983, p. 3). A classificação das séries na sua produção permite o controle da informação, assim como a retomada do ordenamento original, de forma mais natural e obedecendo-se às relações orgânicas (MULLER; FEITH; FRUIN, 1960; LODOLINI, 1993). Desse modo, a essência do registratur assemelha-se àquela do Princípio da Proveniência.

Brenneke (1968) ainda destaca que o respeito à ordem original é considerado por diversos autores como princípio arquivístico secundário, desdobrado da Proveniência; nesse sentido, o autor acredita que a ordem orgânica não se aplica aos documentos arbitrariamente e que a preservação da ordem original no arquivamento pode, por vezes, resultar no desfazimento das relações administrativas e orgânicas que os documentos guardam entre si. Ele critica a utilização indiscriminada desse "princípio", uma vez que a ordem original dada aos conjuntos documentais pode ser considerada um método de arranjo passível de erros humanos e, por conseguinte, um "desrespeito" aos fundos.

O "Sistema Público de Arquivos Francês" subsidiou os autores franceses a discutirem o Princípio da Proveniência, desdobrado no respeito aos fundos e no respeito à ordem original. A Association des Archivistes Français (1991), em 1961, define o Princípio da Proveniência como o agrupamento dos documentos por fundos indivisíveis e prevê o arranjo dos documentos de um fundo segundo sua acumulação orgânica. Essa definição é ratificada por Favier (1985), em 1985, pela Direction des Archives de France (1993), em 1993, e por Rosseau e Couture (1998), em 1994. Os autores canadenses complementam-na e concebem o Princípio da Proveniência como a base da Arquivologia moderna.

De acordo com a Association des Archivistes Français (1991), o Princípio da Proveniência prevê o arranjo dos documentos de um fundo segundo a respectiva acumulação orgânica. Os documentos devem, assim, ser classificados de modo a refletir as funções que os produziram (BELLOTTO, 2006, p. 164).

Os autores italianos Lodolini (1993), Tamblé (1993) e Carucci (2010) basearam-se no metodo storico como pressuposto para a ordenação interna dos conjuntos documentais. Esse método consiste no ordenamento dos arquivos de acordo com a sua organização originária, refletindo a estrutura organizacional das instituições produtoras (CARUCCI, 2010). Ainda segundo essa autora, o ordenamento pelo metodo storico possui duas funções: 1) permitir uma 
análise crítica do fundo, assim como a possibilidade de identificação das relações internas que os documentos guardam; e 2) contribuir para a história da instituição.

Carucci (2010) e Tamblé (1993) igualam o método histórico ao Princípio da Proveniência, apoiando-se em Brenneke (1968). A partir dessa concepção, podemos, portanto, inferir que os autores não consideram, pelo menos explicitamente, o respeito à ordem original e o respeito aos fundos como princípios primários, reconhecendo suas importâncias de forma intrínseca.

Destacamos, como marco conceitual, a definição de respeito aos fundos e respeito à ordem original apresentada por Casanova (1966), em 1928, numa perspectiva intelectual, definição essa inovadora e apoiada por alguns autores como Lodolini (1993) e Bellotto (2006), que não apenas concordam com Casanova (1966), como, também, complementam-no. Casanova apresenta uma visão inédita do ponto de vista de aplicação do Princípio da Proveniência: a recuperação efetiva da informação acontece, segundo ele, quando se observa não apenas o ordenamento original ou a ordem primitiva interna, como, também, a proveniência, a territorialidade e o contexto de criação e utilização do documento. $\mathrm{O}$ entendimento do autor diferencia-se do dos demais estudiosos quando afirma que o respeito aos fundos e a ordem original nem sempre são físicos. Ele exemplifica com situações em que, por motivos de conflitos, um território secciona-se e os fundos são dispersos fisicamente, podendo, mesmo assim, manter a sua proveniência funcional, por meio de um "fórum especial" que mantenha os vínculos de proveniência e de relações administrativas dos documentos, via instrumentos de pesquisa. Nesse caso, respeitam-se os fundos e, ainda que, fisicamente, estejam dispersos e a ordem original tenha sido desfeita, os conjuntos de documentos ainda mantêm as relações orgânicas com sua entidade produtora, via descrição documental.

Portanto, o respeito aos fundos e o respeito à ordem original podem acontecer de forma intelectual, preservando a organicidade dos documentos e as relações jurisdicionais, as quais denominamos "proveniência" (LODOLINI, 1993). O posicionamento de Casanova (1966) demonstra que o respeito aos fundos e o respeito à ordem original são elementos desdobrados do Princípio da Proveniência e que, mesmo em situações em que são "desrespeitados", sobretudo a ordem original, desde que as relações orgânicas sejam mantidas e o condicionamento do documento à sua razão de criação, os produtores e os locais de produção sejam sinalizados, os conjuntos documentais cumprirão sua função precípua enquanto fundos. 
Ademais, após os problemas decorrentes dos processos de colonização e descolonização de territórios e, consequentemente, da descentralização dos estados colonizados (LODOLINI, 1993; CASANOVA, 1966), fez-se necessária a criação de métodos para solucionar os problemas de segregação física dos fundos, como recomendado por Casanova (1966). Ruiz Rodrigues (2008) cita a microfilmagem como uma solução viável para a dificuldade de acesso aos fundos, assim como para a preservação destes.

A discussão quanto à aplicação do respeito à ordem original é, portanto, controversa. Alguns autores mencionam a sua difícil aplicação. Muller, Feith e Fruin (1960) analisam a aplicação desse princípio, assim como Cruz Mundet (2001) e Duchein (1986), sob a ótica de Casanova (1966). Os autores holandeses acreditam que os erros humanos na organização e avaliação dos conjuntos documentais ferem o ordenamento original e tornam seu restabelecimento impossível. Para eles é justificável a não aplicação do ordenamento original em alguns casos.

Duchein (1986) considera o respeito à ordem original dispensável, quando este dificulta a pesquisa. $\mathrm{O}$ autor explica que, em casos de aplicação inadequada do princípio, o arquivista não se obriga a respeitá-lo. Cruz Mundet (2001, p. 233) acredita que sua aplicação é parcial, ou seja, reestabelecer a ordem original física dos documentos correntes em nível básico é viável. Todavia, fazer isso no tocante a fundos é, segundo ele, "ilusório".

$\mathrm{Na}$ América Latina, sob influência do legado arquivístico espanhol, foi adotado o Princípio da Procedência ${ }^{29}$, inicialmente proposto por Heredia Herrera (1991), que preconizou a equivalência entre o respeito aos fundos e a Procedência. Cruz Mundet (2001), MartínPozuelo Campillos (1996) e Ruiz Rodrigues (2008) reconhecem o Princípio da Procedência, todavia divergem do entendimento de Heredia Herrera (1991).

Quanto à identidade da Proveniênica, autores como Tanodi (1961), Association des Archivists Français (1970), Schellenberg (1980), Favier (1985), Cook (1986), Pederson (1987), Eastwood (1992), Society of American Archivist (1993), Direction des Archives de France (1993) e Duranti (1996) compreendem o Princípio da Proveniência como o principal e fundamental na teoria e nas práticas arquivísticas.

Heredia Herrera (1991) considera que Wailly incluiu o respeito à ordem original como atributo aceito universalmente pelos arquivos, embora considerasse o Princípio da Proveniência e a sua aplicação, por meio do respeito aos fundos, como básicos e

\footnotetext{
${ }^{29}$ O Princípio da Procedência se estabeleceu em todos os países como princípio fundamental da Arquivologia, em contraposição à organização dos documentos por temática, proposta no período da Ilustraccíon (HEREDIA HERRERA, 1991, p.33, tradução nossa). É análogo ao Princípio da Proveniência.
} 
fundamentais. Berner (1983) afirma que na Prússia, por volta de 1870, aceitava-se o Princípio de Respeito aos Fundos como básico. Já Cook (1986) mescla alguns dos posicionamentos estudados anteriormente. $\mathrm{O}$ autor destaca a importância do Princípio da Proveniência para a verificação da autenticidade dos documentos, assim como Duranti (1996), citando a importância do seu estudo. $O$ autor apoia o controle da proveniência na entrada dos documentos nos arquivos históricos, analogamente ao registratur prussiano.

Duranti (1996) também entende que o respeito aos fundos e o respeito à ordem original são desdobramentos do Princípio da Proveniência. Ela defende a autenticidade dos documentos em sua essência, ou seja, em sua natureza orgânica. Portanto, Duranti acredita na importância de se conhecer e estudar os produtores e as "multiprocedências" dos arquivos, de forma a se reconstituir as funções, competências, atividades e unidades administrativas para efetuar a descrição e a análise diplomática (DURANTI, 1996, p. 82).

Bellotto (2006), assim como Rosseau e Couture (1998), considera que o Princípio da Proveniência possui um duplo grau: o respeito aos fundos (ordenamento externo) e o respeito à ordem original (ordenamento interno). Assim como Heredia Herrera (1991), Cruz Mundet (2001), Martín-Pozuelo Campillos (1996) e Ruiz Rodrigues (2008) reconhecem o Princípio da Procedência como análogos ao Princípio da Proveniência, contudo com aplicação diferenciada. Martín-Pozuelo Campillos (1996) considera que o Princípio da Procedência possui um duplo grau, sendo o primeiro relativo ao respeito à Proveniência e o segundo, ao respeito à estrutura dos fundos e à ordem interna destes. Para a ordem original, a autora acredita que a procedência dos conjuntos documentais não pode, jamais, mesclar-se com conjuntos de outra procedência. Desse modo, o respeito à estrutura dos fundos estabelece que os documentos, dentro de cada fundo, devam manter a classificação e a ordem própria da instituição de origem, ou seja, devam refletir a organização interna da instituição. Nessa perspectiva, a autora destaca a importância de se separar os documentos por cada unidade administrativa.

Cruz Mundet (2001), assim como Ruiz Rodrigues (2008) e Cortés Alonso (1980), trata do Princípio da Procedência como análogo à Proveniência concentrada no respeito aos fundos. Em suas definições, o Princípio da Procedência consiste em respeitar os fundos, mantendo-os agrupados sem que se mesclem os conjuntos documentais das várias unidades das instituições. Esse posicionamento parece não se destoar das definições apresentadas por Martín-Pozuelo Campillos (1996) e Heredia Herrera (1991) para o Princípio da Procedência. 
No Brasil, o Princípio da Proveniência foi inicialmente estudado por Bellotto (2007), em 1991, na primeira edição de sua obra Arquivo Permanente: Tratamento Documental, por meio de citações de autores internacionais analisados anteriormente: Jenkinson (1965), Cortés Alonso (1980), Schellenberg (1980), Association des Archivists Français (1991) e Society of American Archivists (1993). A autora destaca o Princípio da Proveniência como basilar para a área, desdobrado no respeito aos fundos e no respeito à ordem original. Bellotto (2006) retoma o pensamento francês ao defender o Princípio da Proveniência na organização dos conjuntos documentais arquivísticos e utilizá-lo para justificar a solução da problemática de dispersão de fundos. A autora não explicita uma definição própria do respeito à ordem original, mas complementa Casanova (1966), quando afirma que a "santidade da ordem original ou quietat non movere ${ }^{30}$ é polêmico na Arquivologia em sua aplicação física" (BELLOTTO, 2006).

Lopes (1996) explica que é difícil encontrar, nas instituições brasileiras, grandes avanços na gestão da informação e, consequentemente, na aplicação desses princípios. $\mathrm{O}$ autor afirma que a aplicação da ordem original é difícil e de necessidade discutível no tratamento de massas documentais acumuladas e na intervenção de arquivos correntes. Sousa $(2003)^{31}$ concorda com Lopes (1996) em relação a essa dificuldade de aplicação, em virtude da instabilidade institucional na qual os arquivos são estabelecidos. O cenário arquivístico brasileiro é formado por dois tipos de acervo: os arquivos montados nos setores de trabalho e as massas documentais acumuladas. As instituições deparam-se com problemas de desordem cronológica dos documentos, assim como com a inexistência de políticas públicas arquivísticas (SOUSA, 2003).

A partir dessas diferentes visões, apresentamos a seguir um quadro sintético, que conjuga as diversas abordagens estudadas.

\footnotetext{
${ }^{30}$ A expressão quietat non movere, em latim, foi também citada por Carucci (2010) e significa a inviolabilidade do ordenamento interno dado aos documentos.

${ }^{31}$ Sousa (2003) elaborou um capítulo denominado "Os princípios arquivísticos e o conceito de classificação", do livro Organização e representação do conhecimento na perspectiva da Ciência da Informação, organizado pela professora Georgete Medleg Rodrigues. Embora o texto não faça parte da listagem de obras nacionais inicialmente analisadas em nossa pesquisa, incluímos o autor devido à sua relevante contribuição sobre o assunto.
} 


\begin{tabular}{|c|c|c|c|c|c|}
\hline OBRA & ANO DA $1^{\text {a }}$ EDIÇÃO & $\begin{array}{c}\text { ORIGEM } \\
\text { INSTITUCIONAL } \\
\text { DOS AUTORES }\end{array}$ & $\begin{array}{l}\text { MÉTODOS DE } \\
\text { ORGANIZAÇÃO DOS } \\
\text { DOCUMENTOS }\end{array}$ & $\begin{array}{c}\text { VINCULAÇÃO DA } \\
\text { PROVENIÊNCIA ÀS } \\
\text { FUNÇÕES } \\
\text { ARQUIVÎSTICAS }^{32}\end{array}$ & $\begin{array}{c}\text { RELAÇÕES ENTRE O } \\
\text { PRINCÍPIO DA } \\
\text { PROVENIÊNCIA E SEUS } \\
\text { DESDOBRAMENTOS }\end{array}$ \\
\hline $\begin{array}{l}\text { MULLER, FEITH E } \\
\text { FRUIN (1960) }\end{array}$ & 1898 & Holanda & $\begin{array}{l}\text { Respeito à sequência } \\
\text { lógica da unidade } \\
\text { administrativa. }\end{array}$ & $\begin{array}{l}\text { Produção, avaliação, } \\
\text { classificação e descrição. }\end{array}$ & $\begin{array}{l}\text { A Proveniência, associada ao } \\
\text { respeito aos fundos, é regra } \\
\text { fundamental, considerando-se } \\
\text { que a estrutura administrativa } \\
\text { não se forma arbitrariamente, } \\
\text { mas é consequência lógica da } \\
\text { função administrativa. }\end{array}$ \\
\hline JENKINSON (1965) & 1922 & Inglaterra & Archive group. & $\begin{array}{c}\text { Avaliação, classificação e } \\
\text { descrição. }\end{array}$ & $\begin{array}{l}\mathrm{O} \text { record group se assemelha } \\
\text { aos fundos franceses. Enfase } \\
\text { nos arquivos históricos. }\end{array}$ \\
\hline CASANOVA (1966) & 1928 & Itália & $\begin{array}{c}\text { Metodo storico. Respeito } \\
\text { aos fundos e à ordem } \\
\text { original, seja físico, seja } \\
\text { intelectual. }\end{array}$ & $\begin{array}{c}\text { Avaliação, classificação e } \\
\text { descrição. }\end{array}$ & $\begin{array}{lcr}\begin{array}{l}\text { Entende que } \\
\text { elementos há }\end{array} & \text { outros } \\
\text { observados, } & \text { como } & \text { a } \\
\text { proveniência, } & & \text { a } \\
\text { territorialidade e o contexto } \\
\text { de criação e utilização do } \\
\text { documento. }\end{array}$ \\
\hline BRENNEKE (1968) & 1953 & Alemanha & Registraturprinzip. & $\begin{array}{c}\text { Avaliação, classificação e } \\
\text { descrição. }\end{array}$ & $\begin{array}{lll}\text { Mescla as definições } & \text { de } \\
\text { respeito aos fundos e } & \text { do } \\
\text { Princípio da Proveniência. }\end{array}$ \\
\hline $\begin{array}{c}\text { SCHELLENBERG } \\
(\mathbf{1 9 8 0 )}\end{array}$ & 1956 & EUA & $\begin{array}{l}\text { Valores documentais. } \\
\text { Record group. }\end{array}$ & $\begin{array}{l}\text { Produção, avaliação e } \\
\text { classificação. }\end{array}$ & $\begin{array}{l}\text { O record group se assemelha } \\
\text { aos fundos franceses e ao } \\
\text { Princípio da Proveniência. } \\
\text { Mescla as definições de } \\
\text { respeito aos fundos e de } \\
\text { Proveniência, ressaltando a }\end{array}$ \\
\hline
\end{tabular}

\footnotetext{
${ }^{32}$ Consideraram-se as funções arquivísticas atribuídas por Rousseau e Couture em sua obra Les fonctions de l'archivistique contemporaine, de 1994, quais sejam: produção, avaliação, aquisição, conservação, classificação, descrição e difusão.
} 
Quadro 10 - continuação

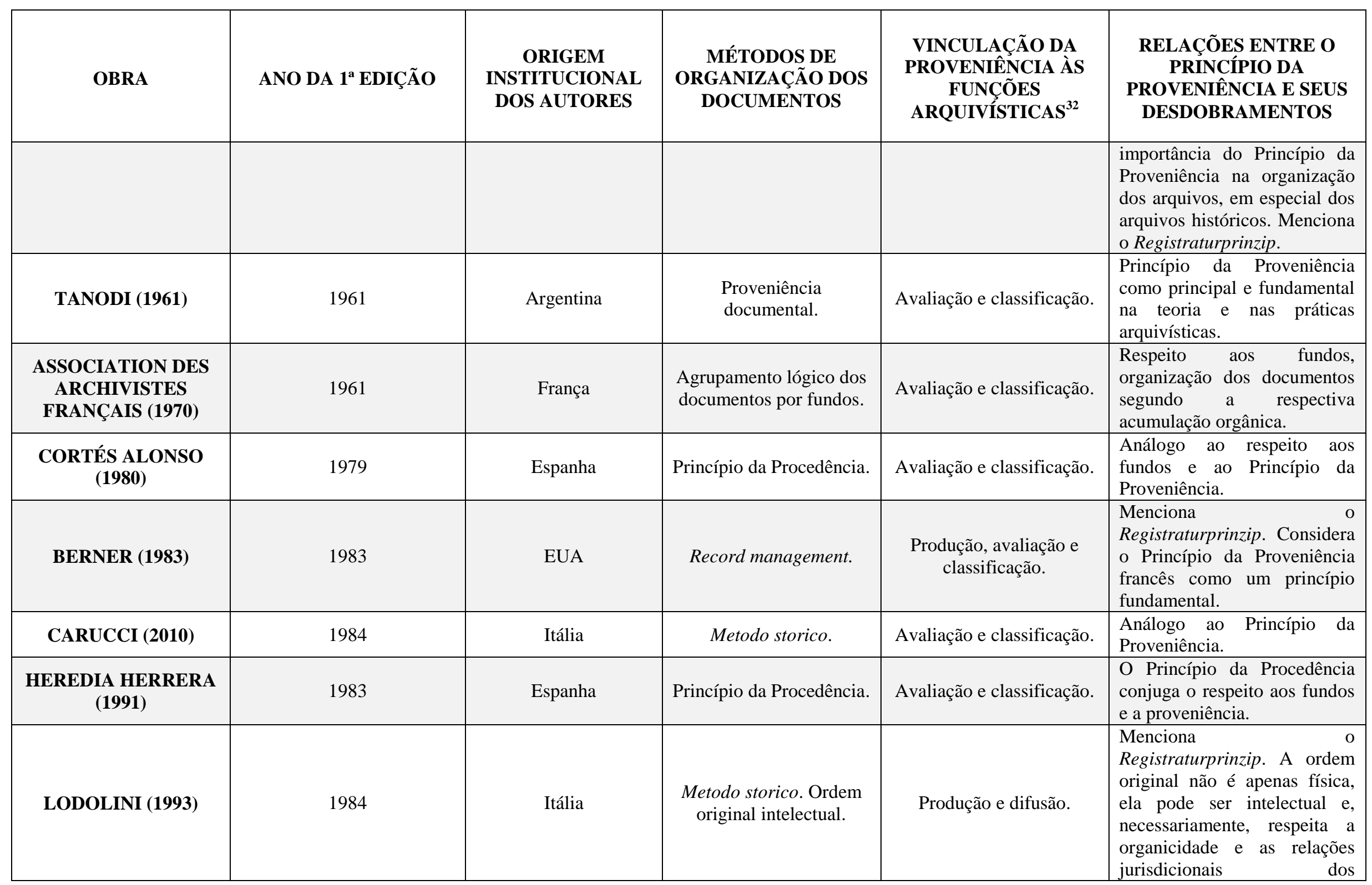


Quadro 10 - continuação

\begin{tabular}{|c|c|c|c|c|c|}
\hline & & & & & documentos. \\
\hline FAVIER (1985) & 1985 & França & $\begin{array}{l}\text { Agrupamento lógico dos } \\
\text { documentos por fundos. }\end{array}$ & Avaliação e classificação. & $\begin{array}{l}\text { Proveniência e } \\
\text { fundos são } \\
\text { importantes considerados } \\
\text { organização dos documentos } \\
\text { e para o uso das informações } \\
\text { arquivísticas. }\end{array}$ \\
\hline COOK (1986) & 1986 & Inglaterra & Record management. & Avaliação e classificação. & $\begin{array}{l}\text { Princípio da Proveniência } \\
\text { como principal e fundamental } \\
\text { na teoria e nas práticas } \\
\text { arquivísticas. }\end{array}$ \\
\hline PEDERSON (1983) & 1986 & Austrália & Record management. & Avaliação e classificação. & $\begin{array}{l}\text { O record group se assemelha } \\
\text { aos fundos franceses e ao } \\
\text { Princípio da Proveniência, } \\
\text { como principal e fundamental } \\
\text { na teoria e nas práticas } \\
\text { arquivísticas. }\end{array}$ \\
\hline EASTWOOD (1992) & 1992 & Canadá & Record management. & Avaliação e classificação. & $\begin{array}{l}\text { Princípio da Proveniência } \\
\text { como principal e fundamental } \\
\text { na teoria e nas práticas } \\
\text { arquivísticas. }\end{array}$ \\
\hline $\begin{array}{l}\text { DIRECTION DES } \\
\text { ARCHIVES DE } \\
\text { FRANCE (1993) } \\
\end{array}$ & 1993 & França & $\begin{array}{l}\text { Agrupamento lógico dos } \\
\text { documentos por fundos. }\end{array}$ & $\begin{array}{l}\text { Avaliação, classificação e } \\
\text { descrição. }\end{array}$ & $\begin{array}{l}\text { Compreende o Princípio da } \\
\text { Proveniência como primordial } \\
\text { no tratamento dos fundos. }\end{array}$ \\
\hline $\begin{array}{c}\text { SOCIETY OF } \\
\text { AMERICAN } \\
\text { ARCHIVIST } \\
(\mathbf{1 9 9 3 )}\end{array}$ & 1993 & EUA & Record management & Avaliação e classificação & $\begin{array}{l}\text { Compara o record group * à } \\
\text { ideia de fundo francesa e ao } \\
\text { Princípio da Proveniência, } \\
\text { como principal e fundamental } \\
\text { na teoria e nas práticas } \\
\text { arquivísticas. }\end{array}$ \\
\hline
\end{tabular}


Quadro 10 - continuação

\begin{tabular}{|c|c|c|c|c|c|}
\hline OBRA & ANO DA $1^{\text {a }}$ EDIÇÃO & $\begin{array}{c}\text { ORIGEM } \\
\text { INSTITUCIONAL } \\
\text { DOS AUTORES }\end{array}$ & $\begin{array}{l}\text { MÉTODOS DE } \\
\text { ORGANIZAÇÃO DOS } \\
\text { DOCUMENTOS }\end{array}$ & $\begin{array}{c}\text { VINCULAÇÃO DA } \\
\text { PROVENIÊNCIA ÀS } \\
\text { FUNÇÕES } \\
\text { ARQUIVÎSTICAS }^{32}\end{array}$ & $\begin{array}{c}\text { RELAÇÕES ENTRE O } \\
\text { PRINCÍPIO DA } \\
\text { PROVENIÊNCIA E SEUS } \\
\text { DESDOBRAMENTOS }\end{array}$ \\
\hline TAMBLÉ (1993) & 1993 & Itália & Metodo storico. & Avaliação e classificação. & $\begin{array}{l}\text { Análogo ao Princípio da } \\
\text { Proveniência. }\end{array}$ \\
\hline $\begin{array}{l}\text { ROUSSEAU E } \\
\text { COUTURE (1994) }\end{array}$ & 1994 & Canadá & $\begin{array}{l}\text { Agrupamento lógico dos } \\
\text { documentos por fundos. }\end{array}$ & Avaliação e classificação. & $\begin{array}{l}\text { Duplo grau do Princípio da } \\
\text { Proveniência: um relacionado } \\
\text { à própria demarcação dos } \\
\text { fundos e o outro, à ordem } \\
\text { original. }\end{array}$ \\
\hline $\begin{array}{l}\text { CRUZ MUNDET } \\
(2001)\end{array}$ & 1994 & Espanha & Princípio da Procedência. & $\begin{array}{c}\text { Produção, avaliação e } \\
\text { classificação. }\end{array}$ & $\begin{array}{lr}\text { Análogo ao Princípio da } \\
\text { Proveniência. } \\
\text { Menciona } \\
\text { Registraturprinzip. }\end{array}$ \\
\hline $\begin{array}{l}\text { RUIZ RODRIGEZ } \\
\text { (2008) }\end{array}$ & 1995 & Espanha & Princípio da Procedência. & Avaliação e classificação. & $\begin{array}{l}\text { Análogo ao Princípio da } \\
\text { Proveniência. }\end{array}$ \\
\hline $\begin{array}{l}\text { MARTÍN-POZUELO } \\
\text { CAMPILLOS (1996) }\end{array}$ & 1996 & Espanha & Princípio da Procedência. & Avaliação e classificação. & $\begin{array}{l}\text { Duplo grau do Princípio da } \\
\text { Procedência, sendo um deles } \\
\text { o respeito à ordem original e o } \\
\text { outro, o respeito aos fundos. } \\
\text { Análogo à Proveniência. }\end{array}$ \\
\hline
\end{tabular}

Fonte: elaboração própria, conforme as obras analisadas.

* Pelo Dicionário de Terminologia do Conselho Nacional de Arquivos (2013), record group se define por: "A body of organizationally related records established on the basis of provenance by an archives for control purposes. A record group constitutes the archives (or the part thereof in the custody of an archival institution) of an autonomous recordkeeping corporate body; See also: collection, fonds, subgroup. Ao definir fond, o dicionário apresenta: "The whole of the documents, regardless of form or medium, automatically and organically created and/or accumulated and used by a particular individual, family, or corporate body in the course of that creator's activities or functions". Para esta pesquisa, entendemos que, embora os termos pareçam análogos, os record groups são os conjuntos documentais organizados por função segundo as atividades pela qual foram criados, enquanto os fonds são conjuntos documentais acumulados organicamente, segundo as características da naturalidade, unicidade e organicidade (DURANTI, 1994; BELOTTO, 2006) que não necessariamente levam em consideração a estrutura funcional. 
Quadro 11 - Síntese dos manuais nacionais analisadas sobre o Princípio da Proveniência

\begin{tabular}{|c|c|c|c|c|c|}
\hline OBRA & ANO DA $1^{\text {a }}$ EDIÇÃO & $\begin{array}{c}\text { ORIGEM } \\
\text { INSTITUCIONAL } \\
\text { DOS AUTORES }\end{array}$ & $\begin{array}{c}\text { MÉTODOS DE } \\
\text { ORGANIZAÇÃO DOS } \\
\text { DOCUMENTOS }\end{array}$ & $\begin{array}{c}\text { VINCULAÇÃO DA } \\
\text { PROVENIÊNCIA ÀS } \\
\text { FUNÇÕES } \\
\text { ARQUIVÎSTICAS }^{33}\end{array}$ & $\begin{array}{c}\text { RELAÇÕES ENTRE O } \\
\text { PRINCÍPIO DA } \\
\text { PROVENIÊNCIA E SEUS } \\
\text { DESDOBRAMENTOS }\end{array}$ \\
\hline BELLOTTO (2007) & 1991 & Brasil & $\begin{array}{l}\text { Herança Francesa. } \\
\text { Agrupamento lógico dos } \\
\text { documentos por fundos. }\end{array}$ & $\begin{array}{l}\text { Avaliação, classificação, } \\
\text { descrição e difusão. }\end{array}$ & $\begin{array}{l}\text { Duplo grau do Princípio da } \\
\text { Proveniência, sendo um deles } \\
\text { o respeito à ordem original e } \\
\text { o outro, o respeito aos fundos. } \\
\text { Propõe o Princípio da } \\
\text { Organicidade. }\end{array}$ \\
\hline LOPES (1996) & 1996 & Brasil & $\begin{array}{c}\text { Herança Francesa. } \\
\text { Agrupamento lógico dos } \\
\text { documentos por fundos. }\end{array}$ & Não apresenta. & $\begin{array}{l}\text { O escopo é a gestão da } \\
\text { informação e a informática. }\end{array}$ \\
\hline JARDIM (1998) & 1997 & Brasil & Não apresenta. & Não apresenta. & $\begin{array}{l}\text { O autor não apresenta, em sua } \\
\text { obra, explicação sobre o } \\
\text { princípio. }\end{array}$ \\
\hline LOPES (1997) & 1997 & Brasil & $\begin{array}{c}\text { Herança Francesa. } \\
\text { Agrupamento lógico dos } \\
\text { documentos por fundos. }\end{array}$ & Não apresenta. & $\begin{array}{lrr}\text { Enfase no } & \text { Princípio } & \text { da } \\
\text { Proveniência. } & \text { Critica } & \text { o } \\
\text { respeito à ordem original. } & \end{array}$ \\
\hline
\end{tabular}

Fonte: elaboração própria, conforme as obras analisadas.

\footnotetext{
${ }^{33}$ Consideraram-se as funções arquivísticas atribuídas por Rousseau e Couture em sua obra Les fonctions de l'archivistique contemporaine, de 1994, quais sejam: produção, avaliação, aquisição, conservação, classificação, descrição e difusão.
} 


\subsubsection{Novos sentidos para a Proveniência}

Após o estudo sequencial da seção anterior, pudemos perceber que o consenso quanto ao Princípio da Proveniência é poroso e em constante movimento no Campo da Informação. Embora os autores tracem a mesma trajetória em direção à Proveniência, como um princípio arquivístico fundamental cuja base se apoia na organicidade, lacunas sobre as suas aplicações ainda perpassam as discussões científicas da área.

Para iniciar as discussões desta seção, partimos da afirmação de Ridener (2009) de que o desenvolvimento da teoria arquivística se dá pela influência das mudanças dos paradigmas (KUHN, 2013), do progresso tecnológico e das constantes evoluções históricas da humanidade. Assim como esse autor, acreditamos que a Arquivologia se pauta em paradigmas em constantes crises e é dessa forma que essa disciplina vem se consolidando no Campo da Informação. Do mesmo modo, é inegável a influência dos acontecimentos históricos na trajetória das evoluções científicas, como preconiza Weber (2006) e como concluímos no capítulo 2.

Considerando Ridener (2009) e as discussões anteriores, propusemos trazer algumas questões sobre o Princípio da Proveniência que vemos como paradigmas em crise na Arquivologia e que nos estimulam a refletir sobre a delimitação desse princípio, sobretudo em sua aplicação prática. Abordaremos aspectos complementares sobre sua descoberta ou origem, desconstrução e redescobrimento, propondo uma reflexão dos novos sentidos contemporâneos acerca do referido princípio.

A origem ou a descoberta da Proveniência, segundo Horsman (2002) e Douglas (2010), deu-se a partir da "manualização" da teoria arquivística feita por Muller, Feith e Fruin (1960), em 1898, na Holanda. Ridener (2009), no entanto, descreve que o início do registro da teoria arquivística aconteceu após a publicação de Josef Anton Oegg, em 1804, denominada Ideen einer Theorie der Archiwwissenschaft, anterior à circular de Wailly em 1841. Segundo o autor, tratava-se de um manual que discorria sobre os procedimentos de tratamento dos acervos e abordava o respeito aos fundos e à organicidade. Pela data, a publicação de Oegg antecedeu o Manual dos Arquivistas Holandeses, embora Ridener (2009) acredite que o conceito de respeito aos fundos tenha sido anunciado por Muller, Feith e Fruin (1960) de maneira pragmática.

Ridener (2009) complementa que o arranjo documental foi o objeto principal do Manual dos Arquivistas Holandeses, tendo como conceitos corolários o 
provenienzprinzip (respeito aos fundos) e o registraturprinzip (ordem original). O autor preconiza que, antes da publicação do manual, os conceitos eram aplicados separadamente; após a sua publicação, os dois conceitos se uniram e formaram o Princípio da Proveniência.

A “nova" Proveniência enunciada por Muller, Feith e Fruin (1960), então, concentrou-se: 1) no estudo da estrutura organizacional na qual os documentos foram produzidos; 2) no arranjo a partir da estrutura administrativa; e 3) na organização dos arquivos, refletindo o contexto de criação e a estrutura organizacional da instituição à qual pertencem. Ridener (2009) finaliza afirmando que essa abordagem de Muller, Feith e Fruin (1960) permite que o arquivista identifique as séries, os grupos e, consequentemente, os fundos dos acervos.

Muller (1910), contudo, critica a forma como o Manual dos Arquivistas Holandeses foi dado como referencial soberano. O autor lembra que, embora não possuísse, na época, uma ampla experiência com os arquivos, foi convidado para elaborar o manual. Poderia, portanto, ter feito uma contribuição mais robusta. Muller (1910) menciona que o manual foi escrito para retratar a realidade holandesa e foi concebido em decorrência de um projeto governamental de padronização da organização dos arquivos holandeses e, por conseguinte, não deveria ter sido aplicado em outros arquivos.

Ridener (2009) ainda lembra que, por volta de 1800, o governo holandês investiu em diversas iniciativas para a consolidação das práticas de tratamento de documentos. O movimento foi liderado por Victor de Stuers ${ }^{34}$ e Theodoor van Riemsdijik $^{35}$. O Manual dos Arquivistas Holandeses foi apenas uma das muitas publicações produzidas, na época, como produto desse grande esforço (RIDENER, 2009). O manual, todavia, passou por um processo de internacionalização e tradução para diversas línguas, o que contribuiu fortemente para a sua popularização (HORSMAN, 2002; RIDENER, 2009).

Ridener (2009) pondera que, quando o manual foi elaborado, o contexto histórico no qual a Holanda se inseria deixa a entender que houve influências significativas de outros países europeus. Essas influências perpassam pelo conceito de

\footnotetext{
${ }^{34}$ Chefe do Departamento de Artes e Ciências do Ministério do Interior holandês e apoiador das iniciativas nas áreas de arquivo, patrimônio histórico, monumentos e museu (RIDENER, 2009, p. 23).

${ }^{35}$ Arquivista do Arquivo Nacional Holandês, de 1887 a 1912, trabalhou para a padronização do sistema de classificação dos acervos dos arquivos estaduais (RIDENER, 2009, p. 23).
} 
fundos, organicidade e papel do arquivista na formatação de métodos de arranjo documental.

Na Alemanha, Brenneke (1968) elabora documentos contendo definições para os fundos arquivísticos que enfatizam o respeito aos fundos e criticam o respeito à ordem original. Para ele, o respeito à ordem original seria um método de arranjo que, por vezes, feriria a organicidade dos fundos e, portanto, passível de ser dispensado (HORSMAN, 2002). Segundo Horsman (2002), Yeo (2010) e Douglas (2010), autores como Carl Gustaf Weilbull $^{36}$, em 1930, na Suécia, e Frank Boles ${ }^{37}$, nos Estados Unidos, concordavam com Brenneke (1968), entendendo que a aplicação externa da proveniência, também denominada respeito aos fundos, tinha coerência, sobretudo, em sua aplicação. Contudo, a dimensão interna a que se referia o respeito à ordem original possuía sérios problemas, assim como discorre Meehan (2010).

Outros autores como Gerhart Enders ${ }^{38}$, em 1962, e Muller (2010) concentraram as discussões na delimitação do Princípio da Proveniência, tendo como base a relação orgânica que os conjuntos documentais guardam com as entidades ou pessoas físicas que o produziram, tecendo críticas à aplicação física da ordem original (HORSMAN, 2002).

Horsman (2002) destaca que muitos autores acreditam que os manuais de Muller, Feith e Fruin (1960) e Brenneke (1968) não apenas registraram a teoria arquivística e delimitaram as questões do respeito aos fundos como também são o marco de origem do Princípio da Proveniência. Douglas (2010), por sua vez, afirma que a teoria arquivística registrada no manual e a forma como esse registro foi assimilado pela comunidade científica são paradigmas clássicos e sugere que a Arquivologia seja vista como uma "ciência normal" (KUHN, 2013). Concordamos com Douglas (2010) no sentido de que a questão da manualização ainda constitui um paradigma em crise em evolução na comunidade científica.

Podemos perceber, a partir da seção anterior, que é clara a predileção dos autores por assumir a herança francesa como precursora oficial do Princípio da Proveniência e

${ }^{36}$ Arquivista sueco da Universidade de Lund, publicou artigo no periódico Scandia Tidschrift for historisk forskning criticando a visão holandesa sobre a ordem original atribuída pelos serviços de registro (SCHELLENBERG, 2006).

${ }^{37}$ Diretor do departamento de Biblioteconomia da Universidade de Michigan, desde 1991; pós-doutor em História, pela Universidade de Michigan; membro da Sociedade dos Arquivistas Americanos. Disponível em: <http://www2.archivists.org/prof-education/faculty/frank-boles>. Acesso em: 12 jan. 2015.

${ }^{38}$ Chefe do Arquivo Alemão de Potsdam; colaborador do Departamento de Arquivologia de Humboldt na Universidade de Berlim; pesquisador na área dos arquivos "modernos" administrativos da Europa (ALLDREDGE, 1963). 
do respeito aos fundos, muito embora haja registros anteriores, em outros locais, com data anterior à Circular de 1841, de Natalis de Wailly. Nesmith (1993) menciona que, no Canadá e nos Estados Unidos, por exemplo, o Princípio da Proveniência foi introduzido a partir da tradição europeia, predominantemente da tradição francesa, em 1950. O precursor dessa "inovação" foi o primeiro arquivista nacional, Douglas Brymner, tendo como sucessor Arthur Doughty. Os dois arquivistas fundaram o departamento de arquivos que, posteriormente, tornou-se o Arquivo Nacional do Canadá e iniciaram a aplicação da Proveniência.

Em 1873, Samuel Muller, enquanto participava de seminários na École Nationale des Chartes, em Paris, registrou, em seus manuscritos" 39 a máxima: "règle absolut: il faut respecter les fonds anciens", ou seja, respeito aos fundos como regra absoluta (HORSMAN, 2002). O estudo desses manuscritos instigou autores como Johannes Papritz e E. Wiersum (1910) a investigarem a real origem do respeito aos fundos e do Princípio da Proveniência.

Muller (1910), em seus estudos, concluiu que o Princípio da Proveniência e o respeito aos fundos não foram uma descoberta francesa. Muitos países europeus, de forma pragmática, já utilizavam, no início do século XIX e até mesmo antes do século XVI, a noção da Proveniência. Na Itália, Francesco Bonaini, por exemplo, utilizava, desde a metade do século XIV, o metodo storico, equivalente ao Princípio da Proveniência. Ele e sua equipe reconheciam que os documentos deveriam refletir a estrutura administrativa à qual pertenciam (HORSMAN, 2002; DOUGLAS, 2010). Todavia, entendemos que, embora práticas em torno do que mais tarde se configuraria como princípio existissem, a empiria ainda não se traduzia em enunciados científicos. De fato, havia práticas e os franceses as demonstraram com registros em documentos estatais.

Em 1881, segundo Douglas (2010), Heirinch Von Sybel, diretor do Arquivo Prussiano, elaborou o regulamento Regulative fur die Ordnungserbeiten im Geheimen Staatsarchiv, que articulava o Princípio da Proveniência (Provenienzprinzip) - no qual os documentos de cada unidade administrativa deveriam ser mantidos juntos - e o respeito à ordem original, tido pelo autor como o Registraturprinzip - no qual os documentos deveriam ser mantidos na ordem em que foram produzidos. A publicação

\footnotetext{
39 Segundo Horsman (2002), os manuscritos de Muller estão preservados na Biblioteca do Arquivo Nacional da Holanda.
} 
desse regulamento teria sido resultado de vários anos de aplicação da proveniência como método de arranjo.

Horsman (2002) concorda com Muller (1910) e Douglas (2010) e complementa que o estudioso Johanne Papritz menciona que as atividades arquivísticas anteriores à publicação da circular francesa - que delimitava o respeito aos fundos e o Princípio da Proveniência - já se embasavam na separação dos fundos pela proveniência. Outros autores como E. Wiersum (1910) e Waldo Leland (1910) também registraram, nos anais do Congresso de Bruxelas (1910), a anterioridade da utilização da proveniência no tratamento documental dos fundos, como fora enunciado mais tarde por Natalis de Wailly.

Wailly, em 1841, não apenas articulou a definição de "proveniência" como a aplicou aos arquivos franceses, o que promoveu grande repercussão e novo significado à preservação da memória institucional. Embora Douglas (2010) discorde, e acredite que Wailly tenha dado a grande contribuição que direcionou diversos outros estudos como, por exemplo, os valores documentais de Schellenberg - sua circular trouxe ao Princípio da Proveniência um status de metodologia e não de princípio, pressuposto básico e essencial.

Horsman (2002) relata que, durante o primeiro século após a Revolução Francesa, o arquivo nacional francês ainda adotava a organização temática, comprometendo as relações orgânicas dos documentos. Wailly, apesar de toda resistência do departamento de arquivo, defendeu seus ideais, formulou e implantou o respeito aos fundos e a proveniência dos fundos franceses. A França - na época, centro político-econômico do mundo - reverberava essas inovações, o que repercutiu em todos os países emergentes. Esse movimento refletiu na teoria arquivística e na trajetória internacional da disciplina, inclusive no Brasil.

Considerando-se que o momento histórico e cultural tem grande influência no desenvolvimento dos conhecimentos científicos, como preconiza Weber (2006), é razoável entender que a herança francesa se inseriu na história da Arquivologia em consequência da visibilidade que a França possuía à época. O regulamento de Wailly foi um grande marco histórico na delimitação do Princípio da Proveniência, embora não se possa ignorar, nesse processo, a contribuição dos demais autores. Dessa maneira, entendemos que, assim como inferimos na seção anterior, o Princípio não possui um 
único lugar de descoberta. Podemos afirmar que sua origem se deu por volta do século XIV, na Europa, com os primeiros registros e aplicações a respeito.

Conforme Horsman (2002), Johanne Papritz, em 1964, no Congresso Internacional de Arquivos, observou que a definição de proveniência anunciada pelos arquivistas holandeses e ratificada pelos fonds franceses possuía problemas quanto à sua aplicação. Segundo Papritz, era necessário inovar e reinventar um novo Princípio da Proveniência, aplicável à realidade dos arquivos no contemporâneo. $\mathrm{O}$ autor complementa mencionando que Papritz, no trabalho publicado no Congresso, afirma que a definição de fundo se tornou a torre de Babel dos arquivos.

Criou-se um Princípio que deveria controlar a padronização dos trabalhos arquivísticos. No entanto, o próprio princípio não poderia ser dominado pelos arquivistas, tendo em vista os problemas de sua aplicação. Os fundos dos arquivos no contemporâneo não se assemelhavam aos fundos da época de Natalis de Wailly, tampouco aos fundos do contexto dos trabalhos de Muller (1910), Johannes Papritz, em 1964, e Wiersum (1910). Nesmith (1993) completa que não se pode apropriar da proveniência em sua totalidade, uma vez que ela foi criada para apoiar o tratamento dos acervos milenares, o que dificilmente se aplicaria à realidade dos arquivos contemporâneos, menos históricos e mais administrativos.

Além disso, após diversos dilemas históricos e problemas de territorialidade, havia muita dispersão, inúmeros fundos misturados, proveniências abaladas, fundos desfeitos e uma grande massa documental acumulada. As insistentes tentativas em reestabelecer a ordem original obstruíram a organicidade, e as relações administrativas muitas vezes se perderam (MEEHAN, 2010).

Millar (2002) reitera que os fundos, apesar de terem a característica da integridade, jamais serão um todo completo. Segundo a autora, os documentos são destruídos arbitrariamente, transferidos de uma instituição para outra antes de chegarem aos arquivos. Os arquivistas, por sua vez, não conseguem manter o fundo todo. Por meio da avaliação, faz-se a seleção daqueles documentos que devem permanecer e a eliminação dos conjuntos que, muito embora façam parte do todo do fundo, perderam a validade institucional. Dessa forma, a autora nos questiona quanto à completude dos fundos e quanto à real aplicação do respeito aos fundos e do Princípio da Proveniência.

Horsman (2002) destaca que, após o Congresso Internacional de Arquivistas e Bibliotecários em Bruxelas, em 1910, o Princípio da Proveniência se tornou ainda mais 
o calcanhar de Aquiles dos arquivos. Com o histórico de ser intocável e ortodoxo, ou "tirano e fundamentalista" (BIRRELL, 1993), não se aplicava a muitas realidades arquivísticas. Percebe-se, segundo ele, que a aplicação da Proveniência permaneceu na penumbra. Muito se discutiu quanto à sua origem e definição, entretanto a sua aplicação permaneceu nas entrelinhas. Muller (1910) tece críticas à "dogmatização" da Proveniência e quebra o paradigma de que a Proveniência é um princípio "sacrossanto". Além do mais, segundo ele, a proveniência já existia e era utilizada como método muito antes de qualquer registro conhecido.

Quanto à aplicabilidade do princípio, Horsman (2002) afirma que todos esses aspectos doutrinários não foram revisados até 1970, quando autores norte-americanos e canadenses iniciaram uma série de estudos em direção a uma nova proveniência, aplicável, sobretudo, à realidade arquivística moderna. O autor destaca a importância do artigo de Michel Duchein (1983) e da "nova" concepção de respeito aos fundos que estimulou outros sentidos para a Proveniência. Apesar de suas raízes francesas, Duchein (1983) contribuiu ao demonstrar a dificuldade de se delimitar fundos fixos, tendo em vista a complexa relação orgânica que os documentos e seus produtores desenvolvem entre si.

Ao longo da história, com o desenvolvimento e a complexidade das sociedades e das instituições, as séries documentais se tornaram intricadas e repletas de nuances que a proveniência tradicional não alcançava. Millar (2002) sugere uma nova configuração para a definição de "fundo", que nos parece apropriada para os documentos no contemporâneo. A autora recomenda que consideremos o fundo não como um todo de documentos produzidos ou acumulados, mas como o conjunto de documentos remanescentes da acumulação e produção institucional.

Sobre essa proposta de Millar (2002), propomos a aplicação, segundo Delmas (2010), do Princípio da Proveniência. O autor acredita que a aplicação do princípio e do respeito aos fundos é intelectual, ou seja, os arquivistas não devem necessariamente ferir a ordenação e a acumulação dada pelos produtores. Para ele, diversas vezes, a própria ordenação registra uma história e um fato administrativo e, portanto, ao fazermos intervenções, desrespeitamos ou comprometemos a memória construída.

Dessa maneira, o arquivista deve formatar instrumentos que reconstruam virtualmente a Proveniência, ressaltando a organicidade e a essência dos arquivos e da Arquivologia. Douglas (2010) e Yeo (2010) confirmam esse entendimento da 
intelectualidade do Princípio da Proveniência, já apresentado por Casanova (1966). Douglas (2010) complementa que a intenção principal de desconstruir o Princípio da Proveniência se guarda na intenção de torná-lo uma construção intelectual, criada a partir da visão dos arquivistas, por entre todas as relações orgânicas em meio aos documentos, produtores e funções documentais. A completude e a complexidade da aplicação do Princípio da Proveniência se baseiam, predominantemente, na junção intelectual entre a história (RIDENER, 2009), a organicidade e a manifestação existente do produtor, registrada na ordenação dada pelos produtores documentais (DOUGLAS, 2010).

Pelas abordagens de Birrell (1993), Millar (2002), Delmas (2010), Douglas (2010) e Yeo (2010), podem inferir que o Princípio da Proveniência, como critica Horsman (2002), permanece "sacrossanto". Todavia, podemos identificar uma nova vestimenta para sua aplicação - uma vez que nos cabe mantê-la, ainda que intelectualmente -, tirando a obrigatoriedade da sua aplicação física aos conjuntos documentais. $\mathrm{O}$ respeito à ordem original e o respeito aos fundos são, nessa visão intelectual, desdobramentos (DOUGLAS, 2010; RIDENER, 2009), ou mesmo métodos, de arranjo documental (DOUGLAS, 2010; HORSMAN, 2002; MILLAR, 2002).

Nossas considerações sobre as origens do Princípio da Proveniência foram resumidas no quadro 12 a seguir: 
Quadro 12 - Síntese das origens do princípio da Proveniência segundo os autores estudados na subseção 3.1.2

\begin{tabular}{|c|c|c|c|c|c|}
\hline AUTOR & $\begin{array}{c}\text { ORIGEM } \\
\text { INSTITUCIONAL }\end{array}$ & ANO & $\begin{array}{l}\text { LOCAL OU } \\
\text { FORMA DE } \\
\text { PRODUÇÃO }\end{array}$ & $\begin{array}{l}\text { TIPO DE REGISTRO/ } \\
\text { TÍTULO }\end{array}$ & PRESSUPOSTO \\
\hline $\begin{array}{l}\text { Francesco } \\
\text { Bonaini }\end{array}$ & Itália & $\begin{array}{l}\text { Século } \\
\text { XIV }\end{array}$ & $\begin{array}{c}\text { Não } \\
\text { identificado }\end{array}$ & Não identificado & $\begin{array}{l}\text { Os documentos } \\
\text { refletem a estrutura } \\
\text { administrativa. }\end{array}$ \\
\hline $\begin{array}{c}\text { Josef Anton } \\
\text { Oegg }\end{array}$ & Holanda & 1804 & Manual & $\begin{array}{l}\text { Ideen einer Theorie der } \\
\text { Archiwwissenschaft }\end{array}$ & $\begin{array}{ll}\text { Manualização } & \text { de } \\
\text { procedimentos } & \text { de } \\
\text { tratamento de acervos. }\end{array}$ \\
\hline $\begin{array}{l}\text { Natalis de } \\
\text { Wailly }\end{array}$ & França & 1841 & $\begin{array}{l}\text { Ministério do } \\
\text { Interior }\end{array}$ & Circular & $\begin{array}{ll}\text { Enunciação } & \text { do } \\
\text { Princípio } & \text { da } \\
\text { Proveniência e } & \text { do } \\
\text { respeito aos fundos. }\end{array}$ \\
\hline $\begin{array}{l}\text { Heinrich } \\
\text { von Sybel }\end{array}$ & Prússia & 1881 & Regulamento & $\begin{array}{c}\text { Regulative fur die } \\
\text { Ordnungserbeiten im } \\
\text { Geheimen Staatsarchiv }\end{array}$ & $\begin{array}{lr}\text { Articulou o Princípio } \\
\text { da Proveniência } \\
\text { associado à } & \text { ordem } \\
\text { original } & \text { na } \\
\text { manutenção } & \text { da } \\
\text { organicidade. } & \end{array}$ \\
\hline $\begin{array}{c}\text { Adolf } \\
\text { Brenneke }\end{array}$ & Alemanha & 1910 & $\begin{array}{l}\text { International } \\
\text { Congress of } \\
\text { librarians } \\
\text { and } \\
\text { Archivist, em } \\
\text { Bruxelas }\end{array}$ & Anais do Congresso & $\begin{array}{l}\text { A aplicação externa } \\
\text { da proveniência - } \\
\text { também denominada } \\
\text { respeito aos fundos - } \\
\text { tinha coerência, } \\
\text { sobretudo em sua } \\
\text { aplicação. Todavia a } \\
\text { dimensão } \\
\text { relativa ao respeito à } \\
\text { ordem arna } \\
\text { possuía } \\
\text { problemas. }\end{array}$ \\
\hline $\begin{array}{l}\text { Samuel } \\
\text { Muller }\end{array}$ & Holanda & 1910 & $\begin{array}{l}\text { International } \\
\text { Congress of } \\
\text { librarians } \\
\text { and Archivist }\end{array}$ & Anais do Congresso & $\begin{array}{l}\text { O Princípio da } \\
\text { Proveniência e o } \\
\text { respeito aos fundos } \\
\text { não foram uma } \\
\text { descoberta francesa. }\end{array}$ \\
\hline E. Wiersum & Bruxelas & 1910 & $\begin{array}{l}\text { International } \\
\text { Congress of } \\
\text { librarians } \\
\text { and Archivist }\end{array}$ & Anais do Congresso & $\begin{array}{lr}\text { A utilização } & \text { da } \\
\text { proveniência } & \text { foi } \\
\text { registrada antes } & \text { da } \\
\text { consolidação } & \text { dos } \\
\text { fundos franceses. } & \\
\end{array}$ \\
\hline $\begin{array}{c}\text { Carl } \\
\text { Weibull }\end{array}$ & Suécia & 1930 & $\begin{array}{c}\text { Não } \\
\text { identificado }\end{array}$ & Não identificado & $\begin{array}{l}\text { A ordem original é } \\
\text { incongruente com a } \\
\text { aplicação } \\
\text { proveniência } \\
\text { respeito aos fundos. }\end{array}$ \\
\hline $\begin{array}{l}\text { Gerhart } \\
\text { Enders }\end{array}$ & $\begin{array}{l}\text { Alemanha } \\
\text { (Berlim) }\end{array}$ & 1962 & Manual & Archivverwaltungslehre & $\begin{array}{l}\text { A Proveniência } \\
\text { demanda que os } \\
\text { conjuntos } \\
\text { documentais } \\
\text { mantenham suas } \\
\text { relações orgânicas, } \\
\text { jurídicas, seja com as } \\
\text { pessoas físicas que os } \\
\text { produziram, seja com }\end{array}$ \\
\hline
\end{tabular}


Quadro 12 - continuação

\begin{tabular}{|c|c|c|c|c|c|}
\hline & & & & & $\begin{array}{l}\text { a instituição } \\
\text { produtora. }\end{array}$ \\
\hline $\begin{array}{l}\text { Johannes } \\
\text { Papritz }\end{array}$ & Alemanha & 1964 & $\begin{array}{c}\text { Congresso } \\
\text { Internacional } \\
\text { de Arquivos }\end{array}$ & Anais do Congresso & $\begin{array}{l}\text { As atividades } \\
\text { arquivísticas já se } \\
\text { embasavam, antes de } \\
1841 \text {, na separação } \\
\text { dos fundos por sua } \\
\text { proveniência. }\end{array}$ \\
\hline $\begin{array}{c}\text { Douglas } \\
\text { Brymner e } \\
\text { Arhur } \\
\text { Doughty }\end{array}$ & Canadá & $\begin{array}{l}1960- \\
1970\end{array}$ & Instituição & $\begin{array}{l}\text { Criação do Arquivo } \\
\text { Nacional Canadense }\end{array}$ & $\begin{array}{l}\text { Introdução } \\
\text { Proveniência, da } \\
\text { sobretudo } \\
\text { Proveniência } \\
\text { Francesa, no Canadá, } \\
\text { segundo a tradição } \\
\text { europeia. }\end{array}$ \\
\hline
\end{tabular}

Fonte: Elaboração própria, conforme autores estudados na subseção.

\subsubsection{Contribuições e repercussões do Princípio da Proveniência para a trajetória da Arquivologia}

A partir da leitura e análise dos manuais arquivísticos, pudemos apreender que o Princípio da Proveniência repercutiu em diversas áreas de estudo da Arquivologia. Está claro, para nós, que a importância do Princípio da Proveniência foi registrada desde o primeiro manual estudado, o Manual dos Arquivistas Holandeses (MULLER; FEITH; FRUIN, 1960). Houve a aderência de diversos autores referenciais na área ao princípio, como relevante atributo para o desenvolvimento do pensamento arquivístico em vários países, incluindo o Brasil. A partir dessa aderência, observamos a diversidade de perspectivas para o mesmo princípio.

Antes de uma análise mais detalhada sobre esse princípio, apresentamos algumas informações que nos parecem pertinentes. Primeiramente, faz-se mister observar as origens nacionais dos autores citados nesta pesquisa, bem como as perspectivas do Princípio da Proveniência, conforme as tabelas 1 e 2 a seguir: 
Tabela 1 - Origens institucionais dos autores dos manuais analisados

ORIGEM INSTITUCIONAL

QUANTIDADE DE AUTORES

\begin{tabular}{|c|c|}
\hline BRASIL & 5 \\
ESPANHA & 5 \\
ITÁLIA & 4 \\
CANADÁ & 3 \\
ESTADOS UNIDOS & 3 \\
FRANÇA & 3 \\
INGLATERRA & 2 \\
ALEMANHA & 1 \\
ARGENTINA & 1 \\
AUSTRÁLIA & 1 \\
HOLANDA & 1 \\
\hline
\end{tabular}

Fonte: Elaboração própria.

Tabela 2 - Perspectivas de abordagens do Princípio da Proveniência pelos autores dos manuais elencados por Marques (2011) e estudados nesta pesquisa

ABORDAGEM

QUANTIDADE DE

AUTORES

RECORDS MANAGEMENT, GROUPS
HERANÇA FRANCESA*
METODO STORICO
PROCEDÊNCIA
REGISTRATURPRINZIP
HERANÇA FRANCESA COM DUPLO GRAU DA
PROVENIÊNCIA**
DUPLO GRAU DA PROVENIÊNCIA
PROCEDÊNCIA COM DUPLO GRAU DA PROVENIÊNCIA

Fonte: Elaboração própria.

* Referimo-nos aos autores que consideram o Princípio da Proveniência com um único grau vinculado ao respeito aos fundos.

** Referimo-nos aos autores que consideram o Princípio da Proveniência com duplo grau, sendo um o respeito aos fundos e o segundo o respeito à ordem original. 
Ao analisar as duas tabelas, notamos que a Arquivologia teve marcos teóricos em todo o mundo, com sua teoria registrada e estudada em diversas realidades. Esse fato concede a ela o status de disciplina em plena ascensão, uma vez que, assim como preconiza Kuhn (2013), há crises e evoluções em constante movimento, o que fortalece a disciplina perante a comunidade científica da informação.

A variedade de abordagens para o Princípio da Proveniência se deu, precipuamente, pelo fato de o princípio ter se originado, concomitantemente, em vários locais e períodos, muito embora possamos observar que as abordagens possuem muitas similaridades no que tange à tendência dos autores em reconhecer a herança francesa. Quando afirmamos que a herança francesa se faz presente e é predominante, o fazemos porque, embora tenhamos terminologias diferentes, a essência do conceito de proveniência permaneceu intacta nos discursos dos autores e bastante presente em nossas análises. Por exemplo, ainda que se tenha o metodo storico, a procedência, o duplo grau e a proveniência se deitam sobre as relações orgânicas que os documentos guardam com as respectivas instituições, com a delimitação dos fundos, como o que estudamos, dos autores franceses, e observamos em manuais de outras origens, como o de Schellenberg (1980). Ressaltamos que a qualidade orgânica ou, segundo Bellotto (2006), o "Princípio" da Organicidade atribui aos conjuntos documentais a característica que os diferencia dos demais documentos, como os bibliográficos e os museológicos.

De fato, o Princípio da Proveniência é corolário para a concretização dos conjuntos documentais à organicidade. Por meio dele, de acordo com os autores estudados, podemos explicar e justificar a problemática de dispersão, reconhecer as unidades administrativas que deram origem aos documentos, assim como salvaguardar a memória institucional dos fundos. A manutenção do contexto de produção, a ordenação interna, a indivisibilidade e a manutenção da proveniência dos fundos contribuem para o fomento da teoria arquivística, assim como para o desenvolvimento da Arquivologia, firmando-a, no cenário científico, como disciplina com características próprias, objeto de estudo delineado (SCHMIDT, 2012) e comunidade científica atuante (MARQUES, 2011).

Destarte, o Princípio da Proveniência, como um dos basilares da organicidade, acompanhado do respeito à ordem original e do respeito aos fundos, orienta a Arquivologia, como disciplina, no estabelecimento do contexto de produção, bem como na organização externa e interna, que reflete a função institucional ou a vida de uma pessoa física representada nos documentos. Destacamos que o respeito aos fundos e a ordem original são 
entendidos por nós como métodos e podem ter sua aplicação de maneira intelectual, assim como descreveu Delmas (2010).

Compreendemos a trajetória histórica do Princípio da Proveniência em três períodos: descoberta/criação, complementação/inovação e, por fim, ratificação de sua definição. Acreditamos que essa divisão proporciona melhor visualização da dinâmica da trajetória percorrida pelo princípio no desenvolvimento da Arquivologia como disciplina científica.

O primeiro período se define pela descoberta/concepção da importância do estabelecimento da organicidade documental, por conseguinte, da construção do Princípio da Proveniência. O segundo período ratifica essa importância, complementa e inova as primeiras concepções e definições do princípio. O terceiro período, o atual, corresponde às diversas transformações e adaptações do Princípio da Proveniência, diante dos inúmeros desafios e demandas da sociedade da informação, inclusive quanto aos novos suportes.

Notamos que o Princípio se relaciona fortemente com as funções arquivísticas, que entendemos, nesta pesquisa, como técnicas que acompanham os métodos (respeito aos fundos e ordem original). De início, a Proveniência teve destaque na classificação e no arranjo de documentos históricos. A organização documental se concentrava no seu ordenamento, tendo em vista a formação da memória histórica institucional. Posteriormente, os autores passam a considerar a aplicação do referido princípio na classificação e avaliação de documentos com valor primário, observando-se o contexto de produção para o instrumento de controle do fluxo informacional da instituição.

Em seguida, percebeu-se que o Princípio da Proveniência perpassava todas as funções arquivísticas, desde o registro e a produção até a descrição e o arranjo dos documentos, não sendo possível restringi-lo a uma idade documental (corrente, intermediário e permanente) ou outra, muito embora a classificação, a avaliação e a descrição possuam maior destaque, conforme a tabela 3 abaixo: 
Tabela 3 - Número de autores que relacionam o Princípio da Proveniência às funções arquivísticas

\begin{tabular}{|c|c|}
\hline FUNÇÖES & QUANTIDADE DE AUTORES \\
\hline Classificação & 25 \\
\hline Avaliação & 24 \\
\hline Produção & 6 \\
\hline Descrição & 6 \\
\hline Difusão & 3 \\
\hline Conservação & 0 \\
\hline Aquisição & 0 \\
\hline
\end{tabular}

Fonte: Elaboração própria.

Diante das várias concepções mapeadas, não é possível identificarmos, de forma precisa, a data e o local de criação do Princípio da Proveniência. Da multiplicidade das atividades humanas e institucionais e consequentes demandas documentais, decorreram a necessidade e a ideia de manutenção das relações orgânicas dos documentos, o que culminou na definição e delimitação do princípio, mesmo que ainda de diversas formas.

Entretanto, é relevante ressaltarmos que, após o redesenho das primeiras definições, dentre as quais destacamos a de Casanova (1966) pudemos observar a aplicação intelectual do Princípio da Proveniência. Esse autor foi determinante no sentido de que, ao retomarmos nossas discussões do capítulo 2, entendemos que o respeito à ordem original é um paradigma (KUHN, 2013) ainda recorrente, que permanece em discussão na comunidade científica arquivística. Não obstante, cabe destacar que as conclusões de Casanova (1966) estão imbuídas do momento histórico em que seu manual foi publicado, com interferência da sua visão "objetiva" (WEBER, 2006) sobre o assunto. Sendo assim, por ser um paradigma “aberto", não se pode considerá-lo princípio científico.

O respeito aos fundos é, por sua vez, um paradigma (KUHN, 2013) que se tornou estável diante da comunidade. Pelas obras, podemos observar que há consenso quanto à sua definição, porém não o há quanto à sua aplicação e "posição" científica. Alguns autores deixam a entender que o respeito aos fundos é um princípio indiscutível, embora outros o considerem parte do Princípio da Proveniência. Pelo consenso majoritário, podemos inferir que o respeito aos fundos é parte da Proveniência, com aplicações físicas e intelectuais. 
O Princípio da Proveniência, por outro lado, tendo em vista o consenso majoritário dos autores, pode ser considerado um princípio arquivístico com aplicações diversas. Infere-se, pelas definições estudadas, que a Proveniência pode ser física ou intelectual, ou seja, de aplicação física na organização dos conjuntos documentais, ou intelectual, no sentido de que, ainda que os conjuntos estejam fisicamente separados, as relações orgânicas devem ser mantidas, pois esse diálogo é essencial para a preservação do conjunto orgânico.

No cerne da análise das definições, não intencionamos elaborar uma definição única: buscamos identificar as convergências e divergências conceituais nas obras estudadas, assim como o entendimento do princípio como corolário arquivístico. De modo geral, as concepções dos autores acerca do Princípio da Proveniência são diferentes e, em alguns casos, não chegam a ser apresentadas ou aprofundadas claramente, sendo perpassadas por características inerentes ao seu momento histórico e ao contexto geográfico relativo ao país de origem institucional dos autores estudados.

De toda forma, parece-nos que esses posicionamentos não interferem na importância do princípio, tampouco na sua relação com os produtores e usuários dos documentos. Percebemos que, de maneira geral, independentemente do posicionamento dos autores quanto à identidade e aos desdobramentos desse princípio, ele se sustenta na organicidade, essência dos documentos de arquivo, e se desdobra no respeito aos fundos de arquivo tendo em vista a sua aplicação.

Inferimos que o Princípio da Proveniência se tornou um instrumento de controle do fluxo informacional, uma vez que contribui para a manutenção das relações orgânicas dos documentos com seus produtores/usuários e auxilia na organização e na conservação física e intelectual dos conjuntos documentais, como unidades indivisíveis.

Ao longo do estudo das obras nacionais, percebemos que a Arquivologia, no Brasil, desenvolveu-se tardiamente, quando comparada à realidade europeia e norte-americana. Assim, quando essa disciplina se estabeleceu no Brasil, a teoria arquivística já estava, de certa forma, avançada nos demais países. Os autores brasileiros vêm contribuindo ricamente, por meio das suas pesquisas e reflexões (MARQUES, 2011), para os avanços dessa disciplina, tanto no cenário nacional como no internacional. Contudo, não observamos contribuições inovadoras desses autores para os princípios arquivísticos, uma vez que eles vêm reproduzindo as definições e aplicações propostas por autores estrangeiros.

Dessa maneira, propomos o seguinte mapa conceitual, que resume nossas acepções nesta subseção: 
Figura 6 - Princípio da Proveniência e suas relações

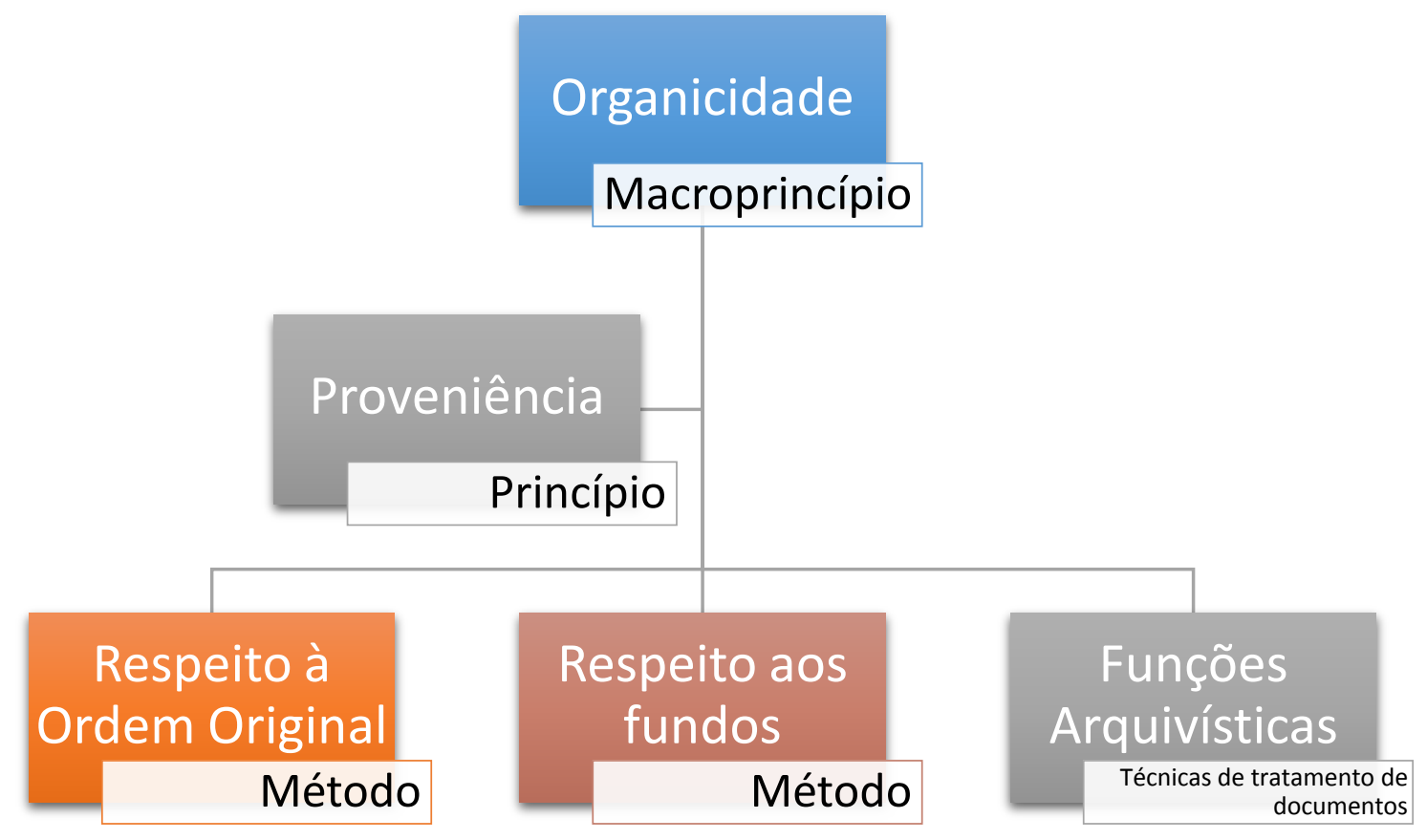

Fonte: Elaboração própria. 


\title{
4 OS MANUAIS DA CIÊNCIA DA INFORMAÇÃO: CONSTRUÇÃO DOS PRINCÍPIOS CIENTÍFICOS DESSA DISCIPLINA
}

\author{
"A informação é um conhecimento inscrito (gravado) sob a forma \\ escrita (impressa ou numérica, oral ou audiovisual). A informação \\ comporta um elemento de sentido. É um significado transmitido a um \\ ser consciente por meio de mensagem inscrita em um suporte \\ espacial-temporal: impresso, sinal elétrico, onda sonora, etc." (LE \\ COADIC, 1996, p. 5).
}

A Ciência da Informação emerge no contexto da $2^{a}$ Guerra Mundial, período no qual houve o fenômeno de "explosão informacional", bem como a latente necessidade de processamento, recuperação, disponibilização e entendimento da progressiva produção informacional (SARACEVIC, 1996; MARQUES et al., 2008). Desde sua gênese, a CI demonstrou possuir características interdisciplinares, recebendo contribuições de diversas disciplinas, como a Linguística, a Psicologia, a Informática, a Documentação e a Biblioteconomia (BORKO, 1968; ROBREDO, 1978; LE COADIC, 1996).

Ao estudar brevemente sua origem, não pudemos identificar, até a elaboração desta pesquisa, uma delimitação clara dos princípios dessa disciplina que perpassassem e pudessem reforçar o seu estatuto científico. Ademais, as discussões em CI se concentram em sua natureza interdisciplinar e em seu objeto de estudo - a informação registrada - e pouco em sua epistemologia (LE COADIC, 1996).

Neste capítulo, propomos o mapeamento dos princípios da CI nos livros da Ciência da Informação citados nas teses (2007-2009), elencados por Menezes (2012). Ao todo, foram estudados 22 livros.

Escolhemos como base metodológica para a organização e o desenvolvimento deste capítulo o que denominamos "Teoria do ciclo da informação de Dodebei (2002)". A partir dessa base, faremos a articulação dos autores, segundo o Método da História Cruzada (WERNER; ZIMMERMANN, 2003), estudando-os por seis eixos de análise, que coincidem com as seis etapas do referido ciclo. Optamos por essa organização em razão de os livros e artigos, diferentemente dos manuais arquivísticos, não tratarem diretamente das questões da cientificidade da CI. Passemos à discussão do capítulo. 


\subsection{Teoria do ciclo da informação de Dodebei (2002)}

Dodebei (2002) fundamenta seu trabalho na representação da memória documentária a partir de modelos de representação do conhecimento. Segundo a autora, os modelos de representação surgem da necessidade social de compreensão da realidade por "representações simplificadas e inteligíveis". A autora preconiza que os modelos são "aproximações seletivas, [que] eliminando aspectos acidentais que permitem o aparecimento dos aspectos fundamentais" (DODEBEI, 2002, p. 21).

Para ela, assim como para Weber (2006), as representações são reflexos dos acontecimentos sócio-históricos. Como entende Popper (2013), o modelo se despoja da subjetividade absoluta e se apoia na objetividade. Não seria a objetividade estreita de Popper (2013), estando mais próxima, como discutimos anteriormente, da objetividade relativa e flexível, uma vez que se pauta em constructos de atores inseridos nos respectivos habitus e comunidades científicas (BOURDIEU, 2011).

Dodebei (2002) complementa que os modelos, tratando do mundo real e das especificidades do conhecimento humano, podem ser considerados como paradigmas estáveis da atividade científica. A autora conclui que os paradigmas (KUHN, 2013) podem ser entendidos como "supermodelos, dentro dos quais os modelos são colocados em escala mais reduzida" (DODEBEI, 2002, p. 20).

A autora teoriza que a CI é um paradigma sistêmico derivado da Teoria Geral de Sistemas, de Von Bertalanffy, ou seja, conceber "o mundo, e o universo, em termos de um grande conjunto interconectado, dentro do qual poder-se-ia separar subconjuntos (ou subsistemas) para análise" (DODEBEI, 2002, p. 21). Assim, de acordo com ela, na CI, as modelagens são paradigmas sistêmicos que sobrepõem uma a outra ao mesmo tempo em que possuem elos e fronteiras sob duas perspectivas: 1) como mapeamento da realidade; e 2) como uma linguagem estruturada de representação do conteúdo, de uso das mensagens.

Os modelos apresentados para a comunidade científica são paradigmas sistêmicos que dialogam entre si, uma vez que a CI, como depõe Borko (1968), é de natureza interdisciplinar. Dodebei (2002) afirma que, por algum tempo, o modelo aceito e aplicado na CI foi o modelo matemático de comunicação de Shannon e Weaver (1962). No entanto, novos paradigmas foram colocados para a comunidade. A autora acredita que a CI não possui um único modelo, mas diversos modelos, elaborados a partir de várias realidades, e que, portanto, a CI "pode ser caracterizada como uma ciência multiparadigmática” (DODEBEI, 2002, p. 20). 
Entendemos que a contribuição de Dodebei (2002) se relaciona com as nossas reflexões do capítulo 2. De fato, a CI apresenta múltiplos paradigmas, que, na medida dos desenvolvimentos socioculturais, evoluem e se estabilizam (WEBER, 2006). Como demonstramos e apreendemos de Trigueiro (2012), os paradigmas podem dialogar entre si e são apresentados à nossa macrocomunidade científica, que chamamos de Campo da Informação.

Nossa proposta da aplicação, de forma interdisciplinar, dos paradigmas às disciplinas do Campo da Informação é ratificada pela autora, muito embora saibamos que, como acredita Popper (2013), dificilmente - por se tratar de uma disciplina em constantes descobertas e, de certa forma, em busca da sua identidade no cenário da informação e do conhecimento -, haverá a irrefutabilidade dos resultados.

Retomando a definição de "teoria" proposta no capítulo 2 - "conjunto de enunciados científicos formulados a partir de crises das disciplinas científicas, obedecendo ao ethos científico, dentro de uma realidade e de necessidades científicas e situado em um contexto histórico-cultural" -, podemos nos basear na proposta de Dodebei (2002) que apresenta um modelo de transferência da informação denominado Ciclo da Informação, o qual entendemos se tratar de uma teoria. A autora ilustra a representação do conhecimento em seis etapas, como demonstrado na figura 7 : 
Figura 7 - Ciclo documentário de Dodebei (2002)

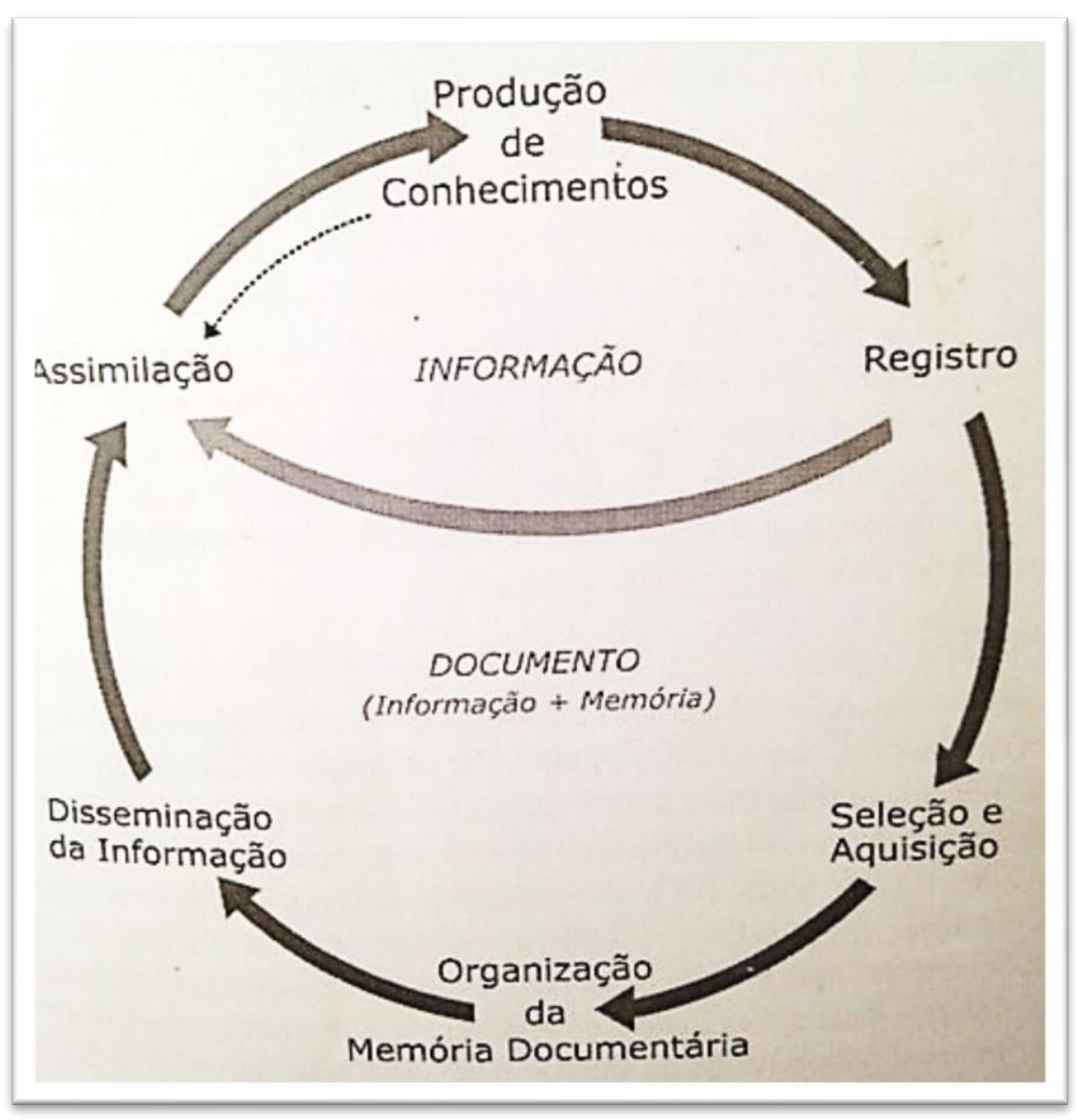

Fonte: Dodebei (2002, p. 25).

Segundo Dodebei (2002), pelas seis etapas do ciclo, compreendemos:

1. Produção de conhecimentos: elaboração de informação ou elaboração de novos paradigmas;

2. Registro: diversidade de suportes e registros;

3. Seleção e aquisição: seleção de informações, identificadas a partir da necessidade dos usuários;

4. Organização da memória documentária: processos de intermediação, tratamento, intervenção, classificação, indexação e ordenação do conhecimento e da informação;

5. Disseminação da informação: transmissão ou difusão do conhecimento e da informação;

6. Assimilação: produção de conhecimento. 
Por essas etapas, organizamos o estudo dos autores em eixos coincidentes com as etapas do Ciclo da Informação. Essa organização visou o arranjo das ideias dos autores, de maneira a facilitar a delimitação dos Princípios da Ciência da Informação.

\subsubsection{Produção de conhecimento e registro}

Antes de discutir a produção de conhecimento, retomaremos a produção da informação, pois entendemos que a informação é insumo do conhecimento, assim como Cintra et al. (1994). Informação, um termo polissêmico que se aplica em diferentes dimensões no Campo da Informação. A CI, entendemos que esta se ocupa da informação registrada e não abrangida pelas outras disciplinas daquele Campo, como a Arquivologia, a Biblioteconomia e a Documentação.

Buscando-se a "origem" da informação, identificamos que, por algum tempo, acreditou-se que a informação supria apenas as necessidades originadas da telecomunicação (MCGARRY, 1999; SHANNON; WEAVER, 1962; DODEBEI, 2002). No entanto, percebeuse que, apesar de ser parte fundamental desse processo, o termo se relaciona apenas à comunicação. Silva e Ribeiro (2008) entendem ainda que se separem conhecimento e comunicação da sua razão de ser - definem informação como um fenômeno humano e social. Contudo, os autores ressaltam que a informação não pode ser reduzida apenas a eventos sociais, tais como notícias, impressões e emoções.

Shannon e Weaver (1962) preconizam que informação é uma medida da organização de um sistema. A "matematização da informação", para esses autores, contribuiu para as questões de quantificação da informação. É possível mensurar a informação em forma de representações que abrangem a informação total (SILVA; RIBEIRO, 2008).

Le Coadic (1996), assim como Dodebei (2002), compreende que informação é conhecimento. Robredo (2003) afirma que a informação possui realidade própria e propriedades fundamentais do universo. Ele descreve que seja praticamente impossível definila, já que ela é tão abstrata quanto a energia. Silva e Ribeiro (2008) acreditam que, embora trabalhados como processos distintos, informação, comunicação e conhecimento são elementos associados. McGarry (1999, p. 10), todavia, descreve que a informação pode ser: 
- Considerada como um quase-sinônimo do termo fato;

- Um reforço do que já se conhece;

- A liberdade de escolha ao selecionar uma mensagem;

- A matéria-prima da qual se extrai o conhecimento;

- Aquilo que é permutado com o mundo exterior e não apenas recebido passivamente;

- Definida em termos de seus efeitos no receptor;

- $\quad$ Algo que reduz a incerteza em determinada situação.

Tão amplamente como acredita Robredo (2003), McGarry (1999) nos apresenta alguns indícios do objeto de estudo da CI, que, assim como seu insumo, possui várias áreas de estudos e aplicações. Não podemos excluir da informação o viés semântico e a respectiva tendência para acompanhar os acontecimentos sociais - tendo em vista que pode ser extraída de conhecimentos existentes, de registros ou de estímulos externos (ROBREDO, 2003). As linguagens, os registros e as ideologias também se associam às diferentes sociedades e aos diferentes períodos e tempos (CINTRA et al., 1994). Robredo $(1978 ; 2003)$ preconiza que a entrada ou a produção de informação é a fase intelectual e social do ciclo da informação e que, quando codificada ou registrada, a informação pode ser armazenada, processada, organizada e recuperada.

De fato, a produção de informação se associa fortemente às situações sociais. O fluxo da informação, assim como seu uso, permuta de tempos em tempos, segundo o movimento dos atores e as realidades em que está inserida. Não podemos ignorar que a produção de informação dialoga com o habitus (BOURDIEU, 2011) e, no caso das disciplinas científicas, tem relação direta com a comunidade científica e seus respectivos paradigmas. McGarry (1999, p. 11) afirma que as ciências "possuem conteúdo empírico mas funcionam como sistemas de raciocínio". Consequentemente, a informação percorre um caminho cíclico, desde sua concepção, embebida de subjetividades ou "objetividades" (WEBER, 2006), até seu encaixe em um contexto que lhe conceda significados e relevâncias, tornando-a um possível paradigma e, talvez, conhecimento.

Assim, McGarry (1999) afirma que a informação é demandada e captada em decorrência das necessidades sociais. A necessidade de informação se relaciona com os eventos sociais e com as percepções humanas. Le Coadic (1996) completa que a necessidade de informação deriva das necessidades materiais, profissionais e pessoais da atividade humana, sendo a informação objeto necessário à realização de transmissão e disseminação Figueiredo (1994) caracteriza a necessidade não apenas como um desejo. A necessidade do 
usuário pode conflitar com desejos expressos e objetiva levar adiante - seja para pesquisa, seja para preencher eventos da sociedade - uma informação. Hjorland (1997) compreende a necessidade da informação como o objeto de trabalho da CI de maneira a traduzi-la, representá-la e torná-la disponível e acredita que o estudo do usuário, bem como, os estudo do meio o qual se insere, seja o método essencial para a estruturação dos sistemas de recuperação.

De fato, os usuários acumulam "novos fatos sobre a sociedade, o mundo físico, e o mundo da consciência individual" (MCGARRY, 1999, p. 46). A união desses elementos proporciona a criação de novas informações, que, em um primeiro momento, está de maneira tácita e, se houver necessidade, será registrada. A retomada dessa informação concede à CI a razão da sua existência: a disponibilização da informação organizada.

Desde a criação da escrita até a atual era digital (MCGARRY, 1999), a informação vem sendo registrada nos mais diversos tipos de suporte, e esse fato não é um problema. Segundo o autor, a problemática é a forma com que os temos utilizado. A ansiedade pela informação nos tem levado a fazer registros socialmente informais e irrecuperáveis. Os registros seguem padrões sociais que são aceitos ideologicamente. $\mathrm{O}$ formato e a forma da informação dialogam com as práticas sociais da comunidade na qual é apresentada.

Como discutimos anteriormente no capítulo 2, as atividades de produção da informação, sobretudo nas comunidades científicas, seguem um ethos (TRIGUEIRO, 2012), ou seja, regras e convenções que as tornam compreensíveis nos respectivos contextos de disseminação. Assim, é imperativo que os atores envolvidos produzam informações e conhecimentos observando as regras da comunidade à qual desejam apresentá-las. Nossa interpretação é ratificada por Silva e Ribeiro (2008): a CI verte para o estudo do comportamento dos produtores da informação e valoração desta pela sociedade

\subsubsection{Seleção, aquisição e organização da memória documentária}

A Ciência da Informação se ocupa da reunião, canalização, tratamento, seleção, armazenamento e recuperação da informação, promovendo o acesso dos usuários, de acordo com suas necessidades (ROBREDO, 1978). Responder às demandas dos usuários nos parece ser um dos pressupostos principais da CI. Todavia, toda informação é necessária e requerida? Toda e qualquer informação é útil? Ou, como suscita Le Coadic (1996, p. 42), "quem necessita da informação? Que tipo de informação? Para qual grupo de pessoas? Por que 
precisam dela?”. Robredo (1978) destaca que o processo, ou o ciclo documentário, não é completo enquanto as etapas de tratamento e conversão da informação em produto “pesquisável” para o usuário não se concretizam. Concordamos com o autor e, a nosso ver, as etapas de seleção e aquisição determinam a profundidade e a capilaridade da informação, transformando a etapa da organização em uma etapa matricial para o processo de recuperação e disponibilidade.

Estamos em contínuo processo de seleção e organização da informação, que muito se adequa à Ciência Normal (KUHN, 2013), ao ethos (TRIGUEIRO, 2012) e às questões das mudanças sociais (WEBER, 2006). McGarry (1999) descreve que nascemos dentro de uma estrutura cultural e comportamental preexistente e "as utilizamos para delas extrair informações sobre o mundo e o lugar que nele ocupamos” (MCGARRY, 1999, p. 63). A seleção, segundo Dodebei (2002), vale-se do princípio da economia, "quer dizer, funcionam como filtros da sociedade da informação, a fim de favorecer o equilíbrio entre as necessidades de informação do público usuário e da oferta da Sociedade” (DODEBEI, 2002, p. 31).

Para Robredo (1978), a seleção é a escolha entre toda a produção mundial de documentos que respondem às disciplinas cobertas pelos serviços de documentação. Foskett (1973) acredita que a seleção se relaciona fortemente com a relevância - a probabilidade de a busca coincidir com a exigência do usuário - e com a revocação (quantidade de itens após a busca) da pesquisa. Cintra et al. (1994), assim como Campos (2001), vincula a seleção da informação ao contexto, ao significado e à utilização da linguagem. Guinchat e Menou (1994) afirmam que a seleção é a escolha dos documentos que a unidade de informação deseja adquirir.

As concepções coincidem no sentido de a seleção visar à redução do escopo da pesquisa a partir da solicitação do usuário. A informação, nesse cenário, necessita de ordenação, estruturação e formatação em representações a serem transmitidas, por canais, aos usuários (MCGARRY, 1999). Assim, Figueiredo (1994) entende que conhecer a comunidade e o usuário é um passo essencial para formatar qualquer organização ou qualquer sistema de informação. Segundo a autora, o estudo da comunidade se concentra em dois pontos: suas características e o significado dessas características e pode ser definido pela respectiva divisão ou classificação por seus componentes e por seus elementos, incluindo-se as necessidades identificadas.

O conhecimento da comunidade na qual se deseja disponibilizar a informação "pode afetar as metas e os objetivos de maneira tão profunda que podem levar a adaptações e ajustes 
que podem vir a criar, para uma entidade já existente, um novo papel ou papeis diferentes" (FIGUEIREDO, 1994, p. 67). Dessa forma, o estudo contínuo da comunidade direciona os métodos e técnicas de organização que serão tomados. Perguntas como "que informação foi usada? E como ela ajudou?" serão constantemente colocadas para a comunidade, que responderá de acordo com a situação social do momento.

Desse modo, os apontamentos de Figueiredo (1994) vão ao encontro do entendimento de Le Coadic (1996). O autor descreve que o estudo das necessidades objetiva melhorar o sistema no qual elas se inserem. É preciso conhecer as circunstâncias que levam o usuário a buscar informação. O usuário, protagonista desse processo, é “encorajado a tornar suas necessidades conhecidas e, ao mesmo tempo, assumir responsabilidade para que estas necessidades de informação sejam atendidas" (FIGUEIREDO, 1994, p. 7). Figueiredo (1994) entende que a seleção da informação se centra em duas subáreas de estudo: o estudo do usuário e a recuperação da informação, sendo o estudo do usuário uma dimensão holística do processo de seleção.

A partir do conhecimento da comunidade, parte-se para a organização da informação propriamente dita. Robredo (1978) descreve que o tratamento da informação perpassa a entrada e o seu processamento. No processamento, a informação passa por classificação, indexação, catalogação, armazenagem e disponibilização para o usuário.

Assim como Robredo (1978), Lancaster (1968; 1993) descreve que o processamento da informação constrói representações que serão apresentadas à comunidade de maneira a suprir suas necessidades. Segundo o autor, as informações selecionadas passam por um processo de identificação, catalogação e condensação, com a formatação de instrumentos como índices e fontes de publicações. Os membros da comunidade utilizam bases de dados, cujos conteúdos são os metadados extraídos do processamento, que visou satisfazer às necessidades de informação.

Dentre as fases de processamento da informação, concordamos com Lancaster (1968; 1993) no sentido de que a classificação é parte essencial e determinante na recuperação da informação para o usuário. Campos (2001) menciona que, no espaço informacional, há necessidade de criação de instrumentos que possibilitem a comunicação e a recuperação da informação, como, por exemplo, a classificação. Guinchat e Menou (1994) entendem que a classificação consiste em atribuir descritores simbólicos, muitas vezes representados por um número. Os autores apresentam a classificação como um método, assim como a indexação, o resumo e a extração de dados. Le Coadic (1996) afirma que a classificação significa ordenar 
de maneira particular, o que resulta na divisão sistemática do espaço do saber, tendo como objetivo dar à informação significado relevante. Para Lancaster (1968; 1993) e Foskett (1973), a classificação é a macroatividade da qual se desdobram a catalogação e a indexação. Os autores ainda comparam a classificação com a indexação. Para Hjorland (1997), a classificação deve ser feita por assunto, visando à recuperação da informação. Segundo o autor, a ordenação da informação é feita a partir do estudo do usuário e da organização da informação.

Para Vickery (1975), a classificação é um instrumento para a seleção e é essencial no processo de busca e recuperação. $\mathrm{O}$ autor acredita que a classificação obedece aos princípios da taxonomia, ou seja, da classificação hierárquica do geral para o particular, dividida em classes, subclasses, grupos, subgrupos e assim por diante. Ainda segundo Vickery (1975), a classificação - assim como estudou Ranganathan, na teoria da classificação faceta - divide-se em facetas. Para ele, a classificação se organiza segundo:

a) a divisão dos assuntos por séries ou facetas;

b) as facetas hierárquicas e logicamente organizadas;

c) os índices remissivos para os termos; e

d) o índice alfabético para as facetas, termos e assuntos.

Campos (2001) aprofunda que a classificação faceta possibilita que os termos de um sistema de informação tenham relações hierárquicas e de significados e ressalta que Ranganathan contribui com sua teoria no enfoque do documento como um registro de documentos, salientando que o processo de classificação associa-se às subjetividades do classificador.

Lancaster (1993) elenca alguns princípios para a classificação. O primeiro deles é o da especificidade, no qual se deve utilizar, da maneira mais específica possível, os termos para a representação da informação, objetivando a menor recorrência na pesquisa. O segundo deles é o princípio da exaustividade, que implica empregar termos para a representação com efetividade suficiente para abranger, de modo completo, todo o conteúdo. O terceiro deles é o princípio da indexação compulsória, no qual o indexador deve optar por utilizar os termos apropriados para descrever o conteúdo de um documento.

Lancaster (1993) completa que, para ele, os princípios da especificidade e da exaustividade não obtiveram desenvolvimento na comunidade científica e, portanto, seriam mais atributos do que princípios. Se retornarmos ao capítulo 2, à definição de "princípio científico" por nós delineada, perceberemos que o raciocínio do autor é coerente, ainda que 
considerando que outros autores fazem menção aos mesmos "atributos". Foskett (1973), por exemplo, menciona que a especificidade e a exaustividade são funções essenciais em sistemas de recuperação da informação, ainda que, para esse autor, a especificidade se refira ao nível de precisão e à extensão dos termos utilizados.

Le Coadic (1996) não menciona esses princípios, mas discorre que a classificação, a catalogação, a descrição e a indexação são métodos de análise dos documentos e das informações. O autor descreve que, assim com afirmou Dodebei (2002), esses métodos extraem dos documentos informações que os representam de forma condensada. Ademais, os métodos da CI se utilizam de recursos semânticos e linguísticos para terem um significado para o usuário. Dessa forma, ratifica-se a necessidade de estudar o meio, o usuário e a comunidade a que se objetiva atender. A classificação deve levar em consideração a análise do conjunto de fatores que a demandam, tais como os momentos históricos, a condição da sociedade e o engajamento interdisciplinar da informação (o diálogo dessa informação com diferentes áreas de estudo). O sistema de classificação deve representar os tipos de linguagens, métodos e técnicas utilizados nos sistemas de recuperação (HJORLAND, 1997; CAMPOS, 2001).

Escolhendo-se uma abordagem ou outra, a essência da seleção, aquisição e organização da informação se concentra na classificação, que nos parece ser a principal atividade dessa etapa obrigatória nos processos de seleção e organização. A classificação, seja por assunto ou funcional, auxilia a organização da informação, bem como a elaboração de representações que serão de extrema importância para o processo de recuperação e resposta aos usuários. Tendo em vista que não pudemos identificar um consenso em relação à forma de realizá-la, tampouco a respeito de seus princípios, a consideraremos um método de organização. Dessa forma, podemos concluir que a classificação pode ser considerada um método essencial dentro do processamento informacional, sendo um processo corolário da CI que possibilita a seleção de informações, segundo as necessidades dos usuários, assim como a avaliação da pertinência da sua aquisição e do seu armazenamento.

\subsubsection{Disseminação e assimilação da informação}

Já nas etapas finais do ciclo da informação, temos a disseminação e a assimilação da informação. Não é possível analisar essas duas etapas sem mencionar a recuperação da informação. A recuperação “consiste numa série de operações lógicas que permitem encontrar 
a informação e os documentos necessários" (ROBREDO, 1978, p. 5). Foskett (1973) preconiza que o processo de recuperação perpassa pela tríade usuário, demanda e retorno da pesquisa, em nível de precisão e recuperação eficientes. Lancaster $(1968 ; 1993)$ acredita que a recuperação da informação depende da maneira pela qual a informação é representada e condensada. Le Coadic (1996) descreve que todo o esforço em organizar a informação, utilizando-se de métodos e técnicas, culmina na recuperação da informação ao usuário. Hjorland (1997) preconiza que a recuperação da informação é a combinação das representações previamente construídas a partir da organização da informação e a demanda do usuário, relacionando-se com a Estatística, a Linguística e a Representação documentária.

Para nós, a recuperação da informação é um misto das perspectivas dos autores. Ela consiste na reunião de operações lógicas que leva em consideração as demandas dos usuários e o retorno das necessidades de forma condensada, eficiente e precisa. Acreditamos, também, que a disseminação, como descrevem Hjorland (1997), Le Coadic (1996), McGarry (1999) e Figueiredo (1994), é um processo resultante da recuperação da informação, após o estudo da comunidade e do usuário, dentro de uma cultura preexistente, por meio de métodos e técnicas.

O processo de disseminação da informação ocorre quando se difundem e se intercambiam codificações, propositadamente, mediante processos e "socialização, educação e aprendizado" (ROBREDO, 2003, p. 22). Dodebei (2002) subordina o conceito de disseminação da informação à divulgação e veiculação de informações, tendo como atributo diferenciador a forma de uso e a construção da memória documentária de cada pessoa. Guinchat e Menou (1994) ressaltam que a disseminação é o objetivo final do tratamento da informação.

A disseminação da informação leva em conta todos os aspectos discutidos para a seleção, aquisição e organização da informação. A autora acredita que a disseminação se vale ainda de aspectos adicionais, como as estratégias "redutoras para impedir a oferta de informação não desejada" (DODEBEI, 2002, p. 37). Nessa etapa, o gestor se concentra na disponibilidade e no acesso do usuário de maneira rápida e eficiente.

Diversas formas podem ser utilizadas para a disseminação da informação, sobretudo as representações documentárias, como descreve Dodebei (2002). Segundo ela, a representação, para a CI, objetiva a mediação da mensagem entre o receptor e o emissor, por processos e produtos de condensação de conteúdo. A condensação se caracteriza pelo resumo do conteúdo dos documentos, representado por um extrato que simboliza a informação como um todo (ROBREDO, 1978). 
O usuário dessa informação pode ou não assimilá-la, produzindo conhecimento, seja o enriquecimento de um conhecimento preexistente, seja a produção de um novo conhecimento (DODEBEI, 2002). Segundo Robredo (2003), a distinção entre conhecimento e informação é a mesma diferença entre conhecimento tácito e explícito. $\mathrm{O}$ autor define que o conhecimento explícito, ou codificado, expressa-se em forma de símbolos, reduzindo a informação, que pode transformar-se em novos conhecimentos, para aqueles que têm acesso aos códigos. O conhecimento tácito não é codificado e, portanto, não formará novos conhecimentos, uma vez que estará acessível apenas ao autor.

A mensuração do conhecimento é uma tarefa árdua, uma vez que se trata de um elemento abstrato e subjetivo. Todavia, podemos testá-lo por meio de produções intelectuais, como as produções científicas. Ainda de acordo com esse estudioso, um conhecimento nunca será completamente codificado: sempre "uma parte do conhecimento situar-se-á em algum ponto do intervalo entre tudo o que é tácito ou tudo o que é codificado" (ROBREDO, 2003, p. 21). Todavia, conforme compreendemos, podemos registrar parte desse conhecimento em suportes, utilizando códigos linguísticos que possuem significado para certa comunidade, como acontece nos textos científicos.

$\mathrm{Na}$ CI, contamos com a participação dos pesquisadores - atores principais do processo de difusão e assimilação -, por meio dos resultados de pesquisas, registrados em publicações científicas, que "servem de base para outros investigadores" (ROBREDO, 1978, p. 3).

O conhecimento científico registrado nos mais diferentes suportes concretiza, pelo ciclo da comunicação, a difusão, assim como descreve Le Coadic (1996). O autor lembra que a institucionalização da CI e do respectivo conhecimento se deu a partir de revistas científicas, produção de artigos, sociedades científicas e criação de cursos e ensinos superiores. Segundo ele, a pesquisa em CI preocupa-se, portanto, com o esclarecimento do problema social do qual essa disciplina se ocupa: o da informação.

A disseminação e a assimilação são, ao mesmo tempo, o final e o início do ciclo, uma vez que, possivelmente, a disseminação gere novas demandas de informação. A assimilação, na perspectiva que apresentamos - a perspectiva da assimilação a partir da produção de conhecimentos científicos -, traz a CI para o Campo da Informação, como proposto por Le Coadic (1996), como uma disciplina institucionalizada em que há muito espaço para conquistas e realizações científicas. 


\subsection{Princípios da Ciência da Informação}

Analisamos os manuais da CI com o objetivo de identificar, explícita e implicitamente, os princípios dessa disciplina. Ao iniciarmos o estudo dos autores, percebemos que não havia princípios explícitos e, portanto, teríamos que fazer uma análise mais complexa e subliminar para delimitar os princípios implicitamente.

Estudamos, no capítulo 2, que princípio científico é entendido como "postulado consensual que, advindo de enunciados e teorias que relatam a realidade empírica de uma disciplina, no caso da Arquivologia e da CI, torna-se base teórica para o funcionamento, amadurecimento e consolidação científica mediante a sua assimilação e validação por cima da comunidade científica (Campo da Informação)". Desse constructo teórico, entendemos que os possíveis princípios da CI deve ser: 1) consensuais; 2) advindos das teorias e enunciados que perpassam a disciplina; e 3) contextualizados na realidade empírica da CI. Partindo dessas considerações, analisamos três aspectos recorrentemente mencionados pelos autores estudados, que inicialmente nos induziram a concebê-los como princípios científicos da disciplina: a sua interlocução contínua com outras disciplinas, a demanda social de informação e a disponibilidade de informação que perpassa a CI.

Dessa forma, iniciamos a análise buscando uma teoria que pudesse abranger todos os autores, mesmo que de forma metodológica, e apoiasse nossa análise. A teoria do ciclo da informação, de Dodebei (2002), proporcionou-nos, de forma sistematizada, essa profundidade de análise e trouxe para esta pesquisa a perspectiva de que o ciclo da informação exemplificaria a pragmática da CI na sua teoria. A CI não possui uma única teoria, mas um conjunto de teorias, que evoluem e se desdobram em diversas outras. Percebemos que, assim como a Arquivologia, as teorias da CI partem da prática e caminham para a pesquisa, para as discussões científicas e para as novas descobertas como uma Ciência Normal (KUHN, 2013). Como dispôs Le Coadic (1996), "a teoria corre atrás dos fatos para compreendê-los. A teoria está atrasada em relação ao empírico". Dentre as diversas teorias, utilizamos a "teoria" do ciclo da informação de Dodebei (2002) como método de estudo deste capítulo e para a análise dos manuais da CI.

Ressaltamos que, por se tratar, em nosso entendimento, de uma teoria, o Ciclo da Informação não dá conta de todas as questões que esta seção pode abranger. Temos, por exemplo, manuais que estudam as questões epistemológicas (LE COADIC, 1996; HJORLAND, 1997; SILVA; RIBEIRO, 1998) e que, em um primeiro momento, não se 
encaixam nas fases propostas pela autora. Contudo, compreendemos, para fins metodológicos, que o ciclo de Dodebei (2002) atendeu aos objetivos do capítulo, bem como a organização das informações as quais apresentamos. Dessa maneira, para aqueles manuais cujos objetos não foram contemplados diretamente pelas fases do ciclo, fizemos uma interpretação com base no Método da História Cruzada, proposto por Werner e Zimmermann (2003), e na articulação das ideias principais dos autores nas seis etapas.

O ciclo proposto pela autora, disposto em seis etapas, proporcionou-nos um caminho para a articulação das ideias apresentadas nos manuais. Contudo, a análise evidenciou, em nossa compreensão, que o ciclo da informação excede as seis etapas de Dodebei (2002). Percebemos que as etapas seleção, aquisição e organização podem desdobrar-se em análise, classificação, indexação e processamento da informação. A análise se caracteriza pela leitura e intepretação da informação. A classificação e a indexação são a categorização e retirada de elementos descritivos do texto, o que fornece à fase de processamento insumos para sistemas de informação.

As etapas disseminação e assimilação se subdividem em recuperação, busca e armazenamento da informação. A recuperação e a busca consideram as demandas dos usuários e o contexto das suas necessidades. $\mathrm{O}$ armazenamento se caracteriza pela forma de preservação da informação, independentemente do suporte em que ela se apresenta.

Percebemos que há vários ciclos da informação, embora observemos que os ciclos geralmente se apoiam na tríade "entrada", "processamento" e "saída", tendo a informação como objeto, a recuperação e a comunicação da informação como objetivo e o usuário como principal "cliente". Notamos, também, que a CI se ocupa do estudo das questões relacionadas à informação, desde sua gênese até sua recuperação. Por sua natureza interdisciplinar (BORKO, 1968), desenvolveu-se a partir de apropriações advindas das várias disciplinas do Campo da Informação, desde seu objeto de estudo até a utilização de suas técnicas.

Como objeto de estudo, identificamos que a CI estuda a informação, que pode ter diversas visões, a depender do olhar do gestor da informação, para o usuário. O estudo de usuários é essencial nesse processo de identificação da informação, que pode ser "importada" de outras disciplinas, como a Biblioteconomia.

Os métodos, apropriados em um primeiro momento das disciplinas do Campo da Informação, precipuamente da Biblioteconomia, localizam-se nas etapas de seleção, aquisição e organização. A classificação, a catalogação e a indexação são citadas como os principais métodos da CI (VICKERY, 1975; LANCASTER, 1993; LE COADIC, 1996; HJORLAND, 
1997; DODEBEI, 2002). As técnicas advêm das representações criadas a partir das demais etapas do ciclo da informação.

Em seguida, após a escolha da teoria, estudamos os autores nos eixos de análise, como descrevemos no capítulo 4. Pudemos observar que os autores não indicam explicitamente os princípios da CI. Talvez, isso se dê pelo fato de que a CI é uma disciplina que ainda busca sua identidade, já que nasce da contribuição de muitas outras disciplinas. Buscamos pontos consensuais que se traduzissem em "representações" (DODEBEI, 2002). Assim, identificamos os seguintes pontos comuns, considerando a teoria do ciclo da informação dessa autora:

Quadro 13 - Aspectos consensuais dos autores da Ciência da Informação

\begin{tabular}{|c|c|c|}
\hline ETAPA & ASPECTOS CONSENSUAIS & Autores \\
\hline Produção & $\begin{array}{l}\text { Atividade intelectual que surge a partir de } \\
\text { necessidades sociais. }\end{array}$ & $\begin{array}{l}\text { Robredo (1978); Cintra et al. (1994); } \\
\text { Figueiredo (1994); Le Coadic (1996); } \\
\text { Hjorland (1997); McGarry (1999); } \\
\text { Campos (2001); Dodebei (2002); Silva } \\
\text { e Ribeiro (2008). }\end{array}$ \\
\hline Seleção & $\begin{array}{l}\text { A oferta e a procura determinam a relevância da } \\
\text { informação. }\end{array}$ & $\begin{array}{l}\text { Robredo (1978); Cintra et al. (1994); } \\
\text { Figueiredo (1994); McGarry (1999); } \\
\text { Campos (2001); Silva e Ribeiro (2008). }\end{array}$ \\
\hline Aquisição & $\begin{array}{l}\text { Entrada de informação no ciclo, seja por } \\
\text { produção, seja por consequência de algum } \\
\text { processo. }\end{array}$ & $\begin{array}{l}\text { Shannon e Weaver (1962); Robredo } \\
\text { (1978); Le Coadic (1996); McGarry, } \\
\text { (1999); Campos (2001); Dodebei } \\
\text { (2002); Silva e Ribeiro (2008). }\end{array}$ \\
\hline Organização & $\begin{array}{l}\text { A classificação da informação é um processo } \\
\text { matricial para o andamento do ciclo da } \\
\text { informação feita a partir do estudo de usuários, } \\
\text { das demandas e das instituições. }\end{array}$ & $\begin{array}{l}\text { Lancaster (1968; 1993); Foskett } \\
\text { (1973); Vickery (1975); Robredo } \\
\text { (1978); Guinchat e Menou (1994); Le } \\
\text { Coadic (1996); Hjorland (1997); } \\
\text { Dodebei (2002); Campos (2001); Silva } \\
\text { e Ribeiro (2008). }\end{array}$ \\
\hline Assimilação & $\begin{array}{l}\text { Difícil de mensurar, registrada em meios } \\
\text { formais de transmissão da informação. }\end{array}$ & $\begin{array}{l}\text { Foskett (1973); Guinchat e Menou } \\
\text { (1994); Hjorland (1997); Le Coadic } \\
\text { (1996); Dodebei (2002); Robredo } \\
\text { (2003). }\end{array}$ \\
\hline
\end{tabular}


Quadro 13- continuação

\begin{tabular}{|c|c|c|}
\hline Difusão & $\begin{array}{l}\text { A partir da recuperação, se disponibiliza a } \\
\text { informação. }\end{array}$ & $\begin{array}{l}\text { Lancaster (1968; 1993); Robredo } \\
\text { (1978); Ingwersen (1992); Figueiredo } \\
\text { (1994); Guinchat e Menou (1994); Le } \\
\text { Coadic (1996); Dodebei (2002); } \\
\text { Robredo (2003); Silva e Ribeiro } \\
(2008) .\end{array}$ \\
\hline
\end{tabular}

Fonte: Elaboração própria.

A etapa da produção demonstrou que a atividade de criação de novas informações depende das necessidades sociais, assim como descrevem Robredo (1978; 2003) e Figueiredo (1994). A relevância da seleção se relaciona com a importância que a informação tem para a comunidade à qual pertence, ratificando o entendimento de Kuhn (2013) quanto à aderência da comunidade a um paradigma. A aquisição comprova que, assim como Popper (2013) preconiza, devemos observar os métodos para a construção de novos saberes, que não são, necessariamente, estritamente objetivos. Na CI, pelo contrário, caracterizam-se por serem mais subjetivos e segundo a realidade empírica, como afirmou Weber (2006). A organização demonstra que as etapas do ciclo da informação são métodos de processamento da informação, já que não há consenso dos autores quanto à hierarquia e à importância da classificação, da indexação e da catalogação. Consensualmente, eles entendem que a classificação é um processo necessário, enquanto a forma e o método de classificação são opcionais.

A assimilação e a difusão não são possíveis sem que ocorram os processamentos de recuperação da informação. A recuperação é consensualmente analisada pelos autores como uma atividade essencial para o processo de acesso, disponibilidade e assimilação da informação. Como podemos vislumbrar no quadro 14 a seguir, a recuperação foi o objeto de análise mais estudado. Observamos, também, que os autores priorizam a representação da informação para apoiar a sua recuperação. Atividades como a indexação e a catalogação auxiliam na construção dessas representações. 


\begin{tabular}{|c|c|c|c|c|}
\hline AUTOR & $\begin{array}{c}\text { ANO DA } \\
\text { PRIMEIRA } \\
\text { EDIÇÃO }\end{array}$ & $\begin{array}{l}\text { OBJETO DO } \\
\text { MANUAL }\end{array}$ & $\begin{array}{c}\text { PRINCIPAL } \\
\text { ATIVIDADE DA } \\
\text { CIÊNCIA DA } \\
\text { INFORMAÇÃ̃O }\end{array}$ & $\begin{array}{c}\text { RELAÇÃO DA } \\
\text { CIÊNCIA DA } \\
\text { INFORMAÇÃO COM } \\
\text { OUTRAS } \\
\text { DISCIPLINAS/ } \\
\text { CIÊNCIAS }\end{array}$ \\
\hline $\begin{array}{l}\text { Shannon; } \\
\text { Weaver } \\
(\mathbf{1 9 6 2 )}\end{array}$ & 1949 & $\begin{array}{l}\text { Comunicação de } \\
\text { mensagens }\end{array}$ & $\begin{array}{c}\text { Processo de } \\
\text { transmissão de } \\
\text { mensagem }\end{array}$ & $\begin{array}{c}\text { Matemática, Estatística e } \\
\text { Lógica }\end{array}$ \\
\hline $\begin{array}{l}\text { Vickery } \\
\text { (1975) }\end{array}$ & 1958 & $\begin{array}{l}\text { Classificação e } \\
\text { indexação da } \\
\text { informação }\end{array}$ & $\begin{array}{l}\text { Processamento para } \\
\text { recuperação da } \\
\text { informação }\end{array}$ & $\begin{array}{l}\text { Biblioteconomia e } \\
\text { Documentação }\end{array}$ \\
\hline $\begin{array}{l}\text { Lancaster } \\
\text { (1968) }\end{array}$ & 1968 & $\begin{array}{l}\text { Recuperação da } \\
\text { informação }\end{array}$ & $\begin{array}{l}\text { Técnicas para a } \\
\text { recuperação da } \\
\text { informação }\end{array}$ & $\begin{array}{c}\text { Biblioteconomia e } \\
\text { Sistemas de Informação }\end{array}$ \\
\hline Foskett (1973) & 1973 & $\begin{array}{l}\text { Métodos de } \\
\text { recuperação da } \\
\text { informação }\end{array}$ & $\begin{array}{l}\text { Organização e } \\
\text { recuperação da } \\
\text { informação }\end{array}$ & $\begin{array}{l}\text { Informática e } \\
\text { Biblioteconomia }\end{array}$ \\
\hline $\begin{array}{l}\text { Robredo } \\
\text { (1978) }\end{array}$ & 1978 & $\begin{array}{l}\text { Recuperação da } \\
\text { informação } \\
\text { documentária }\end{array}$ & $\begin{array}{l}\text { Sistemas de tratamento } \\
\text { da informação } \\
\text { documentária com fins } \\
\text { à recuperação }\end{array}$ & $\begin{array}{c}\text { Documentação, } \\
\text { Biblioteconomia, } \\
\text { Matemática, Lógica, } \\
\text { Linguística, Psicologia, } \\
\text { Informática, Pesquisa } \\
\text { Operacional }\end{array}$ \\
\hline $\begin{array}{c}\text { Guinchat e } \\
\text { Menou (1994) }\end{array}$ & 1981 & $\begin{array}{l}\text { Direcionamentos } \\
\text { sobre as fases do } \\
\text { processamento da } \\
\text { informação }\end{array}$ & $\begin{array}{l}\text { Processamento da } \\
\text { informação }\end{array}$ & $\begin{array}{c}\text { Linguística, Informática, } \\
\text { Biblioteconomia }\end{array}$ \\
\hline $\begin{array}{l}\text { McGarry } \\
\text { (1999) }\end{array}$ & 1981 & $\begin{array}{l}\text { Informação e } \\
\text { conhecimento }\end{array}$ & $\begin{array}{l}\text { Armazenamento, } \\
\text { transmissão e } \\
\text { recuperação da } \\
\text { informação na } \\
\text { sociedade }\end{array}$ & $\begin{array}{l}\text { Psicologia e } \\
\text { Biblioteconomia }\end{array}$ \\
\hline $\begin{array}{l}\text { Lancaster } \\
\text { (1993) }\end{array}$ & 1991 & Indexação & $\begin{array}{l}\text { Sistemas de } \\
\text { informação, } \\
\text { recuperação da } \\
\text { informação }\end{array}$ & $\begin{array}{l}\text { Informática e } \\
\text { Biblioteconomia }\end{array}$ \\
\hline $\begin{array}{l}\text { Ingwersen } \\
\text { (1992) }\end{array}$ & 1992 & $\begin{array}{l}\text { Recuperação da } \\
\text { informação }\end{array}$ & $\begin{array}{l}\text { Organização da } \\
\text { informação para } \\
\text { recuperá-la }\end{array}$ & Psicologia \\
\hline $\begin{array}{c}\text { Cintra et al } \\
\quad(1994)\end{array}$ & 1994 & $\begin{array}{l}\text { Recuperação da } \\
\text { informação, } \\
\text { indexação }\end{array}$ & $\begin{array}{l}\text { Sistemas de } \\
\text { informação, } \\
\text { recuperação da } \\
\text { informação }\end{array}$ & Linguística \\
\hline $\begin{array}{l}\text { Figueiredo } \\
\text { (1994) }\end{array}$ & 1994 & Estudo de usuários & $\begin{array}{c}\text { Proporcionar ao } \\
\text { usuário acesso pleno à } \\
\text { informação }\end{array}$ & Biblioteconomia \\
\hline $\begin{array}{l}\text { Le Coadic } \\
\text { (1996) }\end{array}$ & 1994 & $\begin{array}{l}\text { Epistemologia da } \\
\text { Ciência da } \\
\text { Informação }\end{array}$ & $\begin{array}{c}\text { Posicionamento da CI } \\
\text { enquanto disciplina } \\
\text { científica }\end{array}$ & $\begin{array}{c}\text { Jornalismo, } \\
\text { Biblioteconomia, } \\
\text { Museologia e } \\
\text { Documentação }\end{array}$ \\
\hline $\begin{array}{l}\text { Hjorland } \\
\text { (1997) }\end{array}$ & 1997 & $\begin{array}{l}\text { Recuperação da } \\
\text { informação }\end{array}$ & $\begin{array}{l}\text { Posicionamento da CI } \\
\text { enquanto disciplina } \\
\text { científica. } \\
\text { Representação da } \\
\text { Informação }\end{array}$ & $\begin{array}{l}\text { Psicologia, } \\
\text { Biblioteconomia e } \\
\text { Informática }\end{array}$ \\
\hline
\end{tabular}


Quadro 13- continuação

\begin{tabular}{|c|c|c|c|c|}
\hline AUTOR & $\begin{array}{c}\text { ANO DA } \\
\text { PRIMEIRA } \\
\text { EDIÇÃO }\end{array}$ & $\begin{array}{l}\text { OBJETO DO } \\
\text { MANUAL }\end{array}$ & $\begin{array}{c}\text { PRINCIPAL } \\
\text { ATIVIDADE DA } \\
\text { CIÊNCIA DA } \\
\text { INFORMAÇÃO }\end{array}$ & $\begin{array}{c}\text { RELAÇÃO DA } \\
\text { CIÊNCIA DA } \\
\text { INFORMAÇÃO COM } \\
\text { OUTRAS } \\
\text { DISCIPLINAS/ } \\
\text { CIÊNCIAS }\end{array}$ \\
\hline $\begin{array}{l}\text { Campos } \\
(\mathbf{2 0 0 1})\end{array}$ & 2001 & $\begin{array}{l}\text { Recuperação da } \\
\text { informação, } \\
\text { indexação }\end{array}$ & $\begin{array}{l}\text { Sistemas de } \\
\text { informação, } \\
\text { recuperação da } \\
\text { informação }\end{array}$ & Linguística \\
\hline $\begin{array}{l}\text { Dodebei } \\
(2002)\end{array}$ & 2002 & $\begin{array}{l}\text { Representação da } \\
\text { Informação }\end{array}$ & $\begin{array}{l}\text { Modelagem da } \\
\text { informação de maneira } \\
\text { a criar representações } \\
\text { sociais inteligíveis }\end{array}$ & $\begin{array}{l}\text { Linguística e } \\
\text { Biblioteconomia }\end{array}$ \\
\hline $\begin{array}{c}\text { Silva e } \\
\text { Ribeiro }(2008)\end{array}$ & 2002 & $\begin{array}{l}\text { Epistemologia da } \\
\text { Ciência da } \\
\text { Informação }\end{array}$ & $\begin{array}{l}\text { Posicionamento da CI } \\
\text { enquanto disciplina } \\
\text { científica. }\end{array}$ & $\begin{array}{c}\text { Jornalismo, } \\
\text { Biblioteconomia, } \\
\text { Arquivologia, } \\
\text { Museologia e } \\
\text { Documentação }\end{array}$ \\
\hline $\begin{array}{l}\text { Robredo } \\
(\mathbf{2 0 0 3 )}\end{array}$ & 2003 & $\begin{array}{c}\text { Revisão } \\
\text { Bibliográfica do } \\
\text { histórico da CI }\end{array}$ & $\begin{array}{c}\text { Sistemas e recuperação } \\
\text { da informação }\end{array}$ & $\begin{array}{l}\text { Biblioteconomia, } \\
\text { Documentação e } \\
\text { Informática }\end{array}$ \\
\hline
\end{tabular}

Fonte: Elaboração própria.

Percebemos que os manuais da área possuem uma grande variedade de assuntos, mas que, no geral, as discussões culminam no processo de tratamento da informação, na sua classificação, organização e recuperação. A recuperação da informação está em evidência, uma vez que todos os autores enfatizam sua importância e concentram suas análises sobre o assunto, como podemos observar na tabela 4 abaixo:

Tabela 4 - Número de autores conforme o objeto de estudo dos manuais da CI

\section{OBJETO DE ESTUDO DOS MANUAIS}

Recuperação da informação

Indexação

Epistemologia

Comunicação de mensagens

Classificação

Ciclo da informação

Gestão da informação e do conhecimento

Estudo do usuário

Representação da informação

Histórico da CI

Fonte: Elaboração própria.
QUANTIDADE DE AUTORES

\begin{tabular}{|l|l}
7 \\
4 \\
2 \\
1 \\
1 \\
1 \\
1 \\
1 \\
1 \\
1
\end{tabular}


Sobretudo no capítulo 4, percebemos que a CI dialoga intensamente com diversas disciplinas, para subsidiar seus estudos. Destacamos que, na maioria das obras analisadas, a CI é relacionada com a Biblioteconomia, a Documentação e a Informática, conforme tabela 5 a seguir.

Tabela 5 - Número de autores que relacionam a CI com outras disciplinas científicas

CIÊNCIA OU DISCIPLINA CIENTÍFICA

\begin{tabular}{l}
\hline Biblioteconomia e Documentação \\
Informática \\
Linguística \\
Psicologia \\
Jornalismo \\
Lógica \\
Matemática \\
Museologia \\
Arquivologia \\
Estatística \\
Pesquisa operacional \\
Sistema de Informação \\
Fonte: Elaboração própria.
\end{tabular}

QUANTIDADE DE AUTORES

\begin{tabular}{|l|l}
13 \\
6 \\
5 \\
4 \\
2 \\
2 \\
2 \\
2 \\
1 \\
1 \\
1 \\
1
\end{tabular}

A natureza interdisciplinar da CI concede a ela a possibilidade de compartilhar seus métodos e técnicas de maneira intensa. A exemplo de nossa afirmação, todos os autores que relacionam a CI com a Biblioteconomia e a Documentação mencionam os métodos e técnicas para processar a informação dessas disciplinas. Observamos também que, embora nossos problemas de pesquisa concentrem-se nas relações entre a Arquivologia e a CI, apenas um manual relacionou as duas disciplinas, o publicado por Silva e Ribeiro (2008).

Considerando essa natureza interdisciplinar da CI, percebemos que há uma necessidade contínua de interlocuções desta com outras disciplinas, sobretudo com aquelas do Campo da Informação. Observamos que a CI necessita estar em constantes diálogos, com diversas disciplinas, para que ela mesma se desenvolva. Essa qualidade pode ser traduzida na característica epistemológica da interlocução contínua, na qual a CI deverá permanecer em contínua atualização, por meio de interlocuções com disciplinas que compartilham a informação como objeto de estudo, especialmente com as disciplinas do Campo da Informação. Por essa característica, a CI desenvolve-se dentro de um ethos (TRIGUEIRO, 
2012), respeitando-se as fronteiras das outras disciplinas, ainda que possa compartilhar objetos, métodos e técnicas.

Quanto aos consensos dos autores sobre a necessidade da observância das demandas dos usuários, bem como ao estudo da comunidade em que se inserem, entendemos que a demanda social é um aspecto desencadeador do ciclo informacional, o qual enuncia que toda informação seja selecionada a partir da análise da comunidade e do usuário. A perspectiva da comunidade e do usuário proporciona à CI toda uma visão da realidade, história e subjetividade necessárias (WEBER, 2006) para burilar as teorias existentes e as que estão por vir.

Segundo o ponto de vista de que a informação deve estar acessível e que a restrição ou o sigilo é uma exceção, tornando o acesso à regra e priorizando as questões da recuperação da informação, propusemos a qualidade que entendemos ser o objetivo da CI: a disponibilidade da informação, na qual a informação deve estar disponível ao usuário em linguagem comum à sua realidade social. Esse objetivo representa a questão consensual de que a recuperação da informação é essencial e deve ser um processo contínuo que perpassa todas as etapas do ciclo, além de ser considerada, pelo nosso entendimento, como o objetivo principal da CI.

A característica epistemológica (interlocução contínua), o aspecto desencadeador do ciclo informacional (demanda social) e o objetivo (disponibilidade da informação), como qualidades basilares da CI, funcionam como um ciclo, não havendo hierarquia entre eles, relacionando-se e mesclando-se no constante movimento de evolução, amadurecimento e busca por autonomia da CI, ainda que desprovidos de características de "princípios científicos", como ilustramos na figura 8 a seguir: 
Figura 8 - Qualidades da CI e suas relações

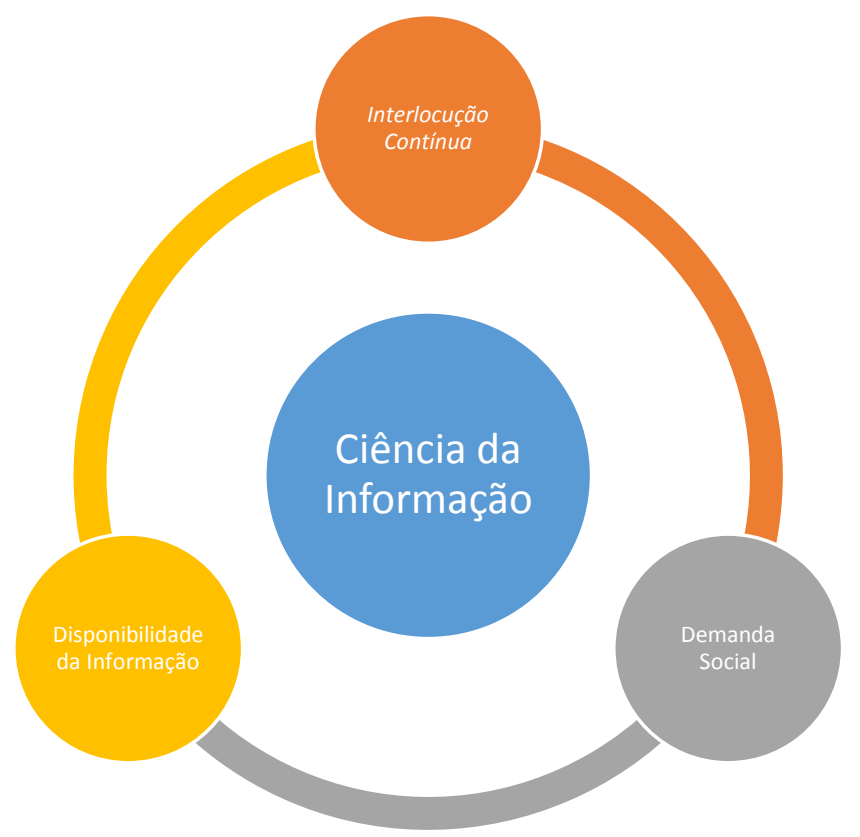

Fonte: Elaboração própria. 


\section{CONSIDERAÇÕES FINAIS}

"No campo da nossa ciência, grandes tentativas de construções
conceituais deviam o seu valor precisamente ao fato de pôr a
descoberto os 'limites' da significação do ponto de vista que lhes
servia de alicerce. Os maiores progressos no campo das ciências
sociais estão ligados 'substantivamente' ao deslocamento dos
problemas práticos da civilização, e assumem a 'forma' de uma
crítica da construção dos conceitos." (WEBER, 2006, p. 97).

$\mathrm{Na}$ atual sociedade da informação, deparamo-nos com a necessidade de estudos sobre os ambientes digitais e a inserção da informação nesses cenários. No entanto, ainda que as tecnologias sejam objeto de estudos em voga, compreender a episteme, a origem, o interior e o desenvolvimento das disciplinas científicas se torna condição sine qua non para as discussões científicas. A epistemologia das disciplinas científicas observa o habitus (BOURDIEU, 2011) da comunidade na qual se inserem, assim como o ethos e a práxis científicas (TRIGUEIRO 2012). Há pontos de contatos entre as disciplinas que podem manter diálogos entre si, compartilhando objetos de estudos, princípios, métodos e técnicas, sem, contudo, comprometer a identidade disciplinar.

Nesta perspectiva de diálogos, esta pesquisa se propôs a adentrar no que consideramos o coração de uma disciplina: os seus princípios científicos. Percebemos que há pouco consenso quanto ao que seja e quais sejam os princípios arquivísticos, o que nos motivou a verticalizar esse tema, a partir da análise de manuais da Arquivologia, mapeados no nosso projeto de iniciação científica da graduação. Diante dessas inquietações, propusemos compreender as demarcações conceituais dos princípios científicos da Arquivologia e da CI, tendo em vista as contribuições na configuração científica dessas disciplinas no Campo da Informação, à luz da Filosofia e da Sociologia da Ciência.

Partindo dos pressupostos da Filosofia e da Sociologia da Ciência para o delineamento dos conceitos de "teoria", "princípio científico", "método" e "técnica", utilizamos esses termos para identificar, nos manuais arquivísticos e nos da CI, os "princípios" que edificam e posicionam as duas disciplinas no Campo da Informação (MARQUES, 2011). Os referenciais teóricos demonstraram que o conceito de "princípio científico" não pode ser estanque, tampouco considerado como verdade absoluta nas Ciências Sociais. Esse conceito se transforma e evolui, assim como as disciplinas às quais pertence. A sua aplicação pode ser intelectual, ou seja, não física, mais vista como uma essência, desde que se respeitem as 
fronteiras da objetividade e da subjetividade e que se leve em consideração os aspectos consensuais e as bases empíricas das disciplinas.

Considerando os objetivos desta pesquisa, pudemos identificar pontos de convergência científica entre a Arquivologia e a CI. Observamos, também, diversos aspectos que as diferem e as tornam disciplinas com identidade própria. A Arquivologia tem como objeto de estudo a informação orgânica registrada (MARQUES, 2011; SCHMIDT, 2012) e tem suas bases consolidadas na organicidade - relações orgânicas dos documentos com as pessoas que os produziram/acumularam e entre si. O objeto de estudo dessa disciplina focaliza, também, as questões de registro da história e da memória institucional, pessoal e administrativa. Nossa análise nos levou ao entendimento de que, para a Arquivologia, o princípio arquivístico da Proveniência pode ser apreendido como elemento essencial para a preservação da organicidade dos arquivos, ou seja, o referido princípio parece traduzi-la. Em tese, embora apenas Bellotto (2006) faça tal afirmação, entendemos que a organicidade se caracteriza por um macroprincípio (que chamamos de "Princípio da Organicidade"), do qual se origina o Princípio da Proveniência e os demais elementos, tais como o respeito aos fundos e à ordem original, aqui entendidos como métodos.

O Princípio da Proveniência é condição necessária para o tratamento da informação orgânica e registrada e valida a organicidade como base fundadora da teoria arquivística, tendo como delimitação externa os fundos (o respeito aos fundos) e o respeito à ordem original, como organização interna desses conjuntos documentais. A organicidade se mantém intocável na caracterização dos documentos de arquivo e pode ser vista como a base teórica da Arquivologia. Estruturada sob a égide da organicidade e do Princípio da Proveniência, distingue-se, portanto, a Arquivologia da CI, inserindo-se aquela na comunidade científica e nas áreas do conhecimento como uma disciplina com identidade própria.

A CI, por sua vez, tem como objeto de estudo toda informação registrada, que também é objeto de estudo das demais disciplinas do Campo da Informação, o que não exclui sua atuação em outros objetos de estudos quando há demanda social e necessidade de diálogo (interdisciplinaridade).

Quanto aos possíveis princípios científicos da CI, nos propusemos a mapeá-los em seus manuais, mas os desafios foram grandes, em razão de dificuldades ligadas à localização e ao acesso às obras; à variedade e, por vezes, à superficialidade dos temas abordados pelos autores; à delimitação de critérios para sistematizar as temáticas; e, por fim, à identificação desses princípios, ainda que com variações nas suas denominações. Observamos, a partir das 
obras analisadas, que muito se discute sobre o objeto de estudo dessa disciplina. No entanto, não identificamos estudos que delimitassem seus princípios científicos.

Retomando o capítulo 2, submetemos os três aspectos recorrentemente citados pelos autores da CI analisados (interlocução contínua, demanda social e disponibilidade de informação) às preposições ou axiomas (TRIGUEIRO, 2012) do que entendemos por "princípio científico" e concluímos que eles: não advêm de enunciados e teorias, pois não pudemos identificar consenso a respeito; relatam, parcialmente, a realidade empírica da CI; são, parcialmente, bases teóricas para o funcionamento e os processos de busca de amadurecimento e consolidação científica da CI; são validados pela comunidade científica, com dissensos.

Portanto, não identificamos princípios para a CI, conforme nossos referenciais teóricos, e propusemos as qualidades da interlocução contínua, da demanda social e da disponibilidade da informação, que auxiliam essa disciplina na sua evolução científica e busca por autonomia e são compartilhados por outras disciplinas.

A interlocução contínua proporciona à CI uma característica epistemológica que lhe é inerente desde sua origem. Dentre as diversas teorias sobre a origem da CI, bem como as circunstâncias e os locais de sua criação, é consenso que a natureza interdisciplinar sempre esteve presente e que, na verdade, resultou na configuração da disciplina da maneira que a conhecemos hoje. Essa característica é parcialmente compartilhada pela Arquivologia, que recebe contribuições profícuas da CI, embora essas contribuições não sejam necessárias para a sua existência tal como percebemos na $\mathrm{CI}$, em relação às contribuições que recebe de outras disciplinas e são, por vezes, condições da sua existência. Como discorremos anteriormente, a organicidade é uma característica única dos arquivos e é o que faz a Arquivologia ter seu objeto próprio.

A disponibilidade da informação, por exemplo, é partilhada com a Arquivologia. No geral, as disciplinas que trabalham com a informação têm a disponibilidade como objetivo final de seus ciclos informacionais. Na CI, esse é o objetivo principal da disciplina, como demonstrou o estudo dos autores analisados. Quanto à demanda social, compreendemos que, por ter a recuperação da informação como corolário para a sua evolução científica, a CI se ampara nos usuários da informação para delimitar a abrangência da informação que processa. Essa relação coma recuperação e os constante diálogos com os usuário funcionam como um gatilho ao ciclo da informação tornando a demanda social um aspecto desencadeador do processo informacional. 
Observamos que a Arquivologia e a CI guardam relações próximas, sobretudo para a preservação da memória e as questões de recuperação e difusão da informação. No que tange ao objeto de estudo, a Arquivologia não o compartilha, uma vez que sua informação é particularmente delimitada pela organicidade. No entanto, o objeto da CI pode se apropriar do objeto de estudo de outras disciplinas do Campo da Informação. Quanto aos princípios, o princípio da Proveniência e o macroprincípio da Organicidade também são exclusivos da Arquivologia. Os aspectos da CI por nós analisados - interlocução contínua, demanda social e disponibilidade de informação podem ser aplicados na Arquivologia. Todavia, essa aplicação estaria no nível dos métodos e das técnicas. Verificamos, ainda, que as funções arquivísticas (produção, avaliação, aquisição, conservação, classificação, descrição e difusão), segundo Couture (1994), muito se assemelham ao ciclo da informação e possuem características predominantemente de técnica (Arquivologia) e método (CI).

Para a Arquivologia, em uma visão geral, o ciclo da informação pode ser compartilhado como técnica no tratamento dos acervos arquivísticos. As funções arquivísticas também podem ser utilizadas pela CI. Obviamente, essas apropriações e compartilhamentos obedecem às fronteiras que as duas disciplinas possuem e se concentram, prioritariamente, na recuperação e difusão da informação de forma mais específica ou mais ampla, respectivamente.

Concluímos, então, que a Arquivologia e a CI possuem diálogos vivos e em evolução, sobretudo no âmbito dos métodos e das técnicas, nos quais a CI parece receber mais do que doar, o que não a impossibilita de possuir sua identidade e colaborar cientificamente com suas contribuições para a atuação de outras disciplinas. A Arquivologia, com uma identidade mais delimitada e madura, objetos e princípios únicos, recorre às técnicas da CI para tratar das questões de recuperação da informação.

As duas disciplinas, por fim, ocupam lugares distintos no Campo da Informação, cada qual com seu espaço de atuação, embora se comuniquem sempre que a informação, objeto dos seus estudos, coincida.

Dessa forma, apresentamos um mapa conceitual (Figura 9), que resume as principais reflexões desta pesquisa e ilustra a identidade e as relações da Arquivologia e da CI. 


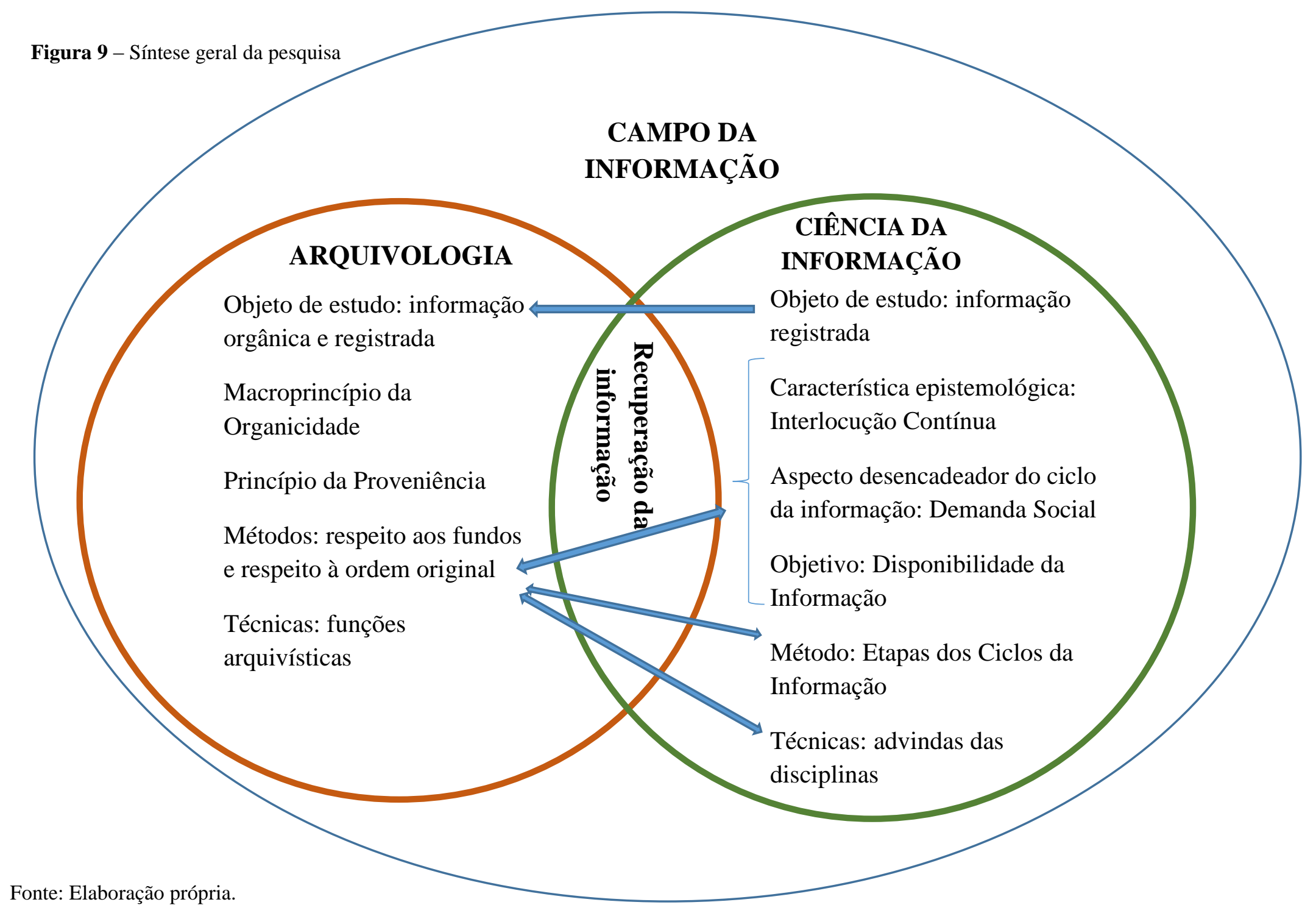


Conforme proposto por Marques (2011), o Campo da Informação, espaço de alianças e conflitos entre as disciplinas que têm por objeto de estudo a informação, abriga, dentre outras, a Arquivologia e a CI. Enquanto a CI se ocupa da informação registrada, de forma geral, a Arquivologia tem, por objeto de estudo, a informação orgânica registrada, produzida e acumulada em decorrência das atividades institucionais e pessoais, que deve ser organizada e preservada de modo a respeitar a organicidade, (macro)princípio máximo da disciplina, traduzido no Princípio da Proveniência, por sua vez desdobrado nos métodos de respeito aos fundos (delimitação externa dos conjuntos documentais) e no respeito à ordem original (organização interna dos referidos conjuntos, conforme os seus contextos de produção e acumulação). Complementarmente, as funções arquivísticas podem ser utilizadas como técnicas, reciprocamente compartilhadas com a CI no âmbito da demanda social de informação (aspecto desencadeador do ciclo da informação), da disponibilidade da informação (objetivo da disciplina) e dos seus métodos (etapas do ciclo da informação).

Como vimos, a interlocução contínua, por meio da interdisciplinaridade (mais evidente na CI do que na Arquivologia), além de favorecer diálogos entre essas disciplinas no Campo da Informação e, particularmente, nas suas comunidades científicas, perpassa as suas evoluções científicas, (de)marcadas por paradigmas em constantes movimentos e princípios que vêm se constituindo perenemente (no caso da Arquivologia, a Organicidade e a Proveniência), sob a conjugação de culturas, significações, histórias, práticas, valores e epistemologias norteadores de uma autonomia científica ainda almejada por ambas as disciplinas.

Que as realidades e "verdades" traduzidas nos princípios científicos sirvam para conduzir as trilhas dessa autonomia, revelando (para a CI), afirmando, aperfeiçoando e consolidando princípios (para a Arquivologia). E que venham outros estudos para demonstrá-los, estudá-los, interpretá-los e refleti-los à luz dessas e de outras disciplinas, para que possamos entendê-las e nos compreender melhor, como membros das suas comunidades científicas, profissionais da informação, arquivistas, professores e pesquisadores. 


\section{RECOMENDAÇÕES}

Segundo o escopo da pesquisa realizada nesta dissertação, contemplando os princípios científicos da Arquivologia e da CI, bem como suas implicações nas identidades dessas disciplinas, acreditamos em pesquisas que contemplem os seguintes temas:

- Implicação das traduções dos manuais na intepretação e aplicação do Princípio da Proveniência, pesquisando e traçando a linha histórica das traduções, objetivando compreender as razões pelas quais elas foram necessárias;

- Estudo nos cursos de Arquivologia do Brasil, sobre o ensino do Princípio da Proveniência, com a realização de entrevistas e visitas em cada Universidade, fazendo-se o levantamento das disciplinas nas quais o Princípio é abordado;

- Estudo sobre a delimitação dos métodos e técnicas da Arquivologia à luz da Filosofia e da Sociologia da Ciência;

- Mapeamento das funções arquivísticas na literatura arquivística nacional e internacional, buscando a influência do Princípio da Proveniência na aplicação dessas funções;

- Mapeamento do Princípio da Proveniência nas teses e dissertações que tenham como objetos de estudo temas arquivísticos;

- Mapeamento dos princípios da CI nas teses, dissertações e periódicos;

- Estudo epistemológico sobre os métodos e as técnicas da CI à luz da Filosofia e da Sociologia da Ciência;

- Estudo, nos cursos de pós-graduação stricto sensu, do ensino dos princípios da CI;

- Investigação dos perfis dos autores dos manuais da CI, objetivando compreender suas origens institucionais e as abordagens teóricas que estudam. 


\section{REFERÊNCIAS}

ABBAGNANO, Nicolas. Dicionário de Filosofia. 6. ed. São Paulo: Editora WMF Martins Fontes, 2012.

ALLDREDGE, Everett O. Reviews of books: Archivverwaltungslehre, von Gerhart Ender. In: The America Arquivist. 1963. p. 383-384. Disponível em: <http://americanarchivist.org/doi/pdf/10.17723/aarc.26.3.4187811g64715630>. Acesso em: 12 jan. 2015.

ARQUIVO NACIONAL. Dicionário Brasileiro de Terminologia Arquivística. Rio de Janeiro: Arquivo Nacional, 2005.

ASSOCIATION DES ARCHIVISTES FRANÇAIS. Manuel d'Archivistique: théorie et pratique des Archives publiques en France. Paris: Direction des Archives de France, 1991.

BAUTIER, Robert-Henri. Les Archives. In: L'Histoire et ses méthodes. Dir. de Charles Samaran. Paris: Gallimard, 1961.

BELlOTO, Heloísa Liberati. Arquivos Permanentes: tratamento documental. 4. ed. Rio de Janeiro: Fundação Getúlio Vargas, 2006.

O sentido dos arquivos. In: I Ciclo de Palestras da Diretoria de Arquivos

Institucionais - DIARQ. Universidade Federal de Minas Gerais. Belo Horizonte, 2014. (comunicação oral). Disponível em: <https://www.ufmg.br/diarq/anexos/wfd_14012774465385cc06bbb48-fala_bellotto.pdf >. Acesso em: 19 nov. 2014.

BERNER, Richard C. Archival theory and practice in the United States: a historical analysis. Seattle: University of Washington Press, 1983.

BIRRELL, Andrew. The tyranny of tradition. In: Canadian archival studies and the rediscovery of provenance. Metuchen, N. J. \& London: The Scarecrow Press. Inc. 1993.

BORKO, Harold. Information Science: what is it? American Documentation, Washington, v. 19, n. 1, jan. 1968.

BOURDIEU, Pierre. Razões Práticas: sobre a teoria da ação. 11. ed. Campinas: Papirus, 2011.

BRENNEKE, Adolf. Archivistica: contributo alla teoria ed alla storia archivistica europea. Milano: Per i tipi dell'editore, 1968.

CAMPOS, Maria Luiza de Almeida. Linguagem documentária: teorias que fundamentam sua elaboração. Niterói-RJ: EdUFF, 2001. 
CARUCCI, Paola. Le fonti archivistiche: ordinamento e conservazione. Roma: Carocci Editore S.p.A, 2010.

CASANOVA, Eugenio. Archivística. 2. ed. Siena: Stab. Arti Grafiche Lazzeri, 1966.

CINTRA, Ana Maria et al. Para entender as linguagens documentárias. São Paulo: Polis, 1994.

COOK, Michael. The management of information from archives. England: Gower Publishing Company, 1986.

CORTÉS ALONSO, Vicenta. Documentacion y documentos. Madrid: Ministerio de Cultura/Dirección General de Bellas Artes, Archivos y Bibliotecas, 1980.

CRESWELL, John W. Research Design: qualitative, quantitative and mixed methods approaches. 2. ed. University of Nebraska. Lincoln: SAGE Publications, 2003.

CRUZ MUNDET, José Ramón. Manual de Archivística. 7. ed. Madrid: Fundación Sãnchez Ruipérez, Pirámide, 2001.

DELMAS, Bruno. Arquivos para quê? São Paulo: Instituto Fernando Henrique Cardoso (IFHC), 2010.

DIRECTION DES ARCHIVES DE FRANCE. La pratique archivitique française. Paris, 1993.

DISTUTACION PROVINCIAL DE SEVILLA. Archivística: estúdios básicos. Sevilla: Disputaciona Provincial, 1981.

DODEBEI. Vera Lúcia Doyle. Tesauro: linguagem de representação da memória documentária. Rio de Janeiro: Interciência, 2002.

DOUGLAS, Jennifer. Origins: evolving ideas about the Principle of Provenance. In: EASTWOOD, Terry; MACNEIL, Heather (Org.). Currents of Archival Thinking. Santa Barbara: Libraries Unlimited (Santa Barbara - United States), 2010.

DUCHEIN, Michel. O respeito aos fundos em arquivística: princípios teóricos e problemas práticos. Arquivo \& Administração, Rio de Janeiro, v. 10, n. 3, abr. 1982/ago. 1986.

Theoretical principles and practical problems of respect des fonds in Archival

Science, Archivaria, n. 16, 1983, p. 64. Disponível em: <http://journals.sfu.ca/archivar/index.php/archivaria/article/viewFile/12648/13813>.

Acesso em: 2 nov. 2014.

DURANTI, Luciana. Diplomática: usos nuevos para una antigua ciencia. Carmona (Sevilla): S \& C ediciones, 1996.

The archival bond. In: Archives and museum informatics 11. 1997. p 213Disponível em: 
<https://www.researchgate.net/publication/226554280_The_Archival_Bond>. Acesso em: 17 fev. 2016.

EASTWOOD, Terry. The Archival Fonds: from theory to practice. Ottawa: Bureau of Canadian Archivists, 1992.

FAVIER, Jean. Les archives. 7. ed. Paris: Presses Universitaires de France, 1985.

FIGUEIREDO, Nice Menezes de. Estudo de uso e usuário da informação. Brasília: IBICT, 1994.

FONSECA, Maria Odila Kahl. Arquivologia e Ciência da Informação. Rio de Janeiro: FGV, 2005.

FOSKETT, Antony Charles. A abordagem temática da informação. Tradução Briquet Lemos. Brasília: Ed. Universidade de Brasília, 1973.

FREIRE, Gustavo Henrique. Ciência da Informação: temática, histórias e fundamentos. Perspectivas em Ciência da Informação, Belo Horizonte, v. 11, n. 1, p. 6-19, jan./jun. 2006.

GALlEGO DOMÍNGUEZ, Olga; LÓPEZ GÓMEZ, Pedro. Artxibistikan Sarrera/Introducción ala Archivística Bilbao. Eusko Jaurlaritzaren Argitalpen Zerbitzu Nagusia/Servicio Central de Publicaciones. Gobierno Vasco, 1989.

GOMES, Henriette Ferreira. Interdisciplinaridade e Ciência da Informação: de característica a critério delineador de seu núcleo principal. In: DataGramaZero, Rio de Janeiro, v. 2, n. 4, ago./2001. Disponível em: <http://www.dgz.org.br/ago01/F_I_aut.htm>. Acesso em: 20 ago. 2013.

GUINCHAT, C.; MENOU, M. Introdução geral às ciências e técnicas da informação e documentação. 2.ed. rev. aum. Brasília: Ibict;CNPq, 1994. 540 p.

HEREDIA HERRERA, Antonia. Archivística general: teoría y práctica. 5. ed. Sevilla: Gráficas del Sur, 1991.

HJORLAND, Birger. Information seeking and subject representation: an activitytheorical approach to information science. London: Greenwood Press, 1997.

HORSMAN, Peter. The last dance of the phonix or the re-discovery of the archival fonds. In: Archivaria, n. 54, Canada, 2002, p. 1-23. Disponível em: <http://journals.sfu.ca/archivar/index.php/archivaria/article/viewArticle/12853>. Acesso em: 2 nov. 2014.

INGWERSEN, Peter. Information retrieval interaction. London: Taylor Graham, 1992. Disponível em: <http://pure.iva.dk/ws/files/31047349/Ingwersen_IRI.pdf>. Acesso em: 10 nov. 2015. 
INTERNACIONAL COUNCIL ON ARCHIVES, Multilingual archival terminology. 2013. Disponível em: 〈http://www.ciscra.org/mat/mat/term/289>. Acesso em: $17 \mathrm{fev}$. 2016.

JARDIM, José Maria. A gestão da informação: as organizações, os arquivos e a informática aplicada. Rio de Janeiro: Arquivo Público do Estado do Rio de Janeiro, 1997.

Sistemas e políticas públicas de arquivos no Brasil. Niterói: EDUFF, 1995.

Transparência e opacidade do Estado no Brasil: usos e desusos da informação governamental. Niterói: EDUFF, 1998.

JENKINSON, Hilary. A Manual of archive administration. 2. ed. London: Percy Lund, Humphries and Co., 1965.

JUVÊNCIO, Carlos Henrique. O Mundaneum no Brasil: o Serviço de Bibliographia e Documentação da Biblioteca Nacional e seu papel na implementação de uma rede de informações científicas. 2014. 190 f.,il. Dissertação (Mestrado em Ciência da Informação)—Universidade de Brasília, Brasília, 2014.

KOTHARI, C. R. Research methodology: methods and techniques. New Delhi: New Age International Limited, 2004.

KUHN, Thomas. A estrutura das revoluções científicas. Tradução Beatriz Vianna Boeira e Nelson Boeira. 12. ed. São Paulo: Perspectiva, 2013.

LANCASTER, Frederick Wilfrid. Indexação e resumos: teoria e prática. Tradução Antonio Agenor Briquet Lemos. Brasília: Briquet Lemos, 1993.

Information retrieval systems: characteristics, testing, and evaluation. New York: John Wiley \& Sons, 1968.

LE COADIC, Yves-François. A Ciência da Informação. Brasília-DF: Briquet de Lemos/Livros, 1996.

LELAND, W. G. The work of the public archives commission of the American Historical Association. In: Congrès de Bruxelles, 1910, Bruxelas. Congrès de Bruxelles - Congrès International des Archivistes et des Bibliothécaires, 1910. Disponível em: <https://archive.org/stream/BrusselsCongress 1910/brussels_congress_1910\#page/n0/mo de/2up>. Acesso em: 12 dez. 2014.

LODOLINI, Elio. Archivistica: principios y problemas. 2. ed. Madrid: Editorial La Muralla, S. A., 1993.

LOPES, Luís Carlos. A informação e os arquivos: teorias e práticas. Niterói: EDUFF, 1996. 
MARQUES, Angelica Alves da Cunha. Interlocuções entre a Arquivologia nacional e internacional no delineamento da disciplina no Brasil. 2011. $399 \mathrm{f}$. Tese (Doutorado em Ciência da Informação) - Universidade de Brasília, Brasília, 2011.

Os espaços e os diálogos da formação e configuração da Arquivística como disciplina no Brasil. 2007. 298 f. Dissertação (Mestrado em Ciência da Informação) Universidade de Brasília, Brasília, 2007.

et al. Relações teórico-epistemológicas entre a Arquivística e a Ciência da Informação na perspectiva social. In: I Fórum Internacional de Arquivologia, 2008, João Pessoa. I Fórum Internacional de Arquivologia - A revolução e significado do conhecimento em Arquivologia, 2008.

MARTÍN-POZUELO CAMPILLOS, María Paz. La construcción teórica en archivística: el principio de procedencia. Madrid: Universidad Carlos III, 1996.

MATA CASTILLON, José Manuel. Las administraciones autonómicas y la unidade de la profesiós de archivero. In: Archivística: estudios básicos. Sevilla: Diputación Provincial, 1983.

MCGARRY, Kevin. O contexto dinâmico da Informação: uma análise introdutória. 2. ed. Brasília: Briquet de Lemos. 1999.

MEEHAN, Jennifer. Rethinking original order and personal records. Archivaria. n. 70. Canada, p. 2010. 27-44, Disponível em: <http://journals.sfu.ca/archivar/index.php/archivaria/article/viewArticle/13294>. Acesso em: 10 dez. 2014.

MENEZES, Vinícius Souza de. Os livros nas teses: implicações políticoepistemológica no saber da Ciência da Informação. 2012. 171 f. Dissertação (Mestrado em Ciência da Informação) - Universidade Federal da Bahia, Salvador, 2012.

MILLAR, Laura. The Death of the fonds and the resurrection of Provenance: archival context in space and time. Archivaria. n. 53, 2002. Disponível em: <http://journals.sfu.ca/archivar/index.php/archivaria/article/view/12833>. Acesso em: 23 dez. 2014.

MULLER, Samuel. De orde van den inventaris. In: Congrès de Bruxelles, 1910, Bruxelas. Congrès de Bruxelles - Congrès International des Archivistes et des Bibliothécaires, $1910 . \quad$ Disponível em: <https://archive.org/stream/BrusselsCongress1910/brussels_congress_1910\#page/n0/mo de/2up>. Acesso em: 12 dez. 2014.

MULLER, S.; FEITH, J. A.; FRUIN, R. Manual de arranjo e descrição. 2. ed. Rio de Janeiro: Arquivo Nacional, 1960.

NATIONAL ARCHIVES AND RECORDS SERVICE. A modern archives reader: basic readings on archival theory and practice. Washington: General Services Administration, 1984. 
NESMITH, Tom. Introduction: Archival Studies in English speaking Canada and the North American Rediscovery of Provenance. In: Canadian archival studies and the rediscovery of provenance. Metuchen, N.J. \& London: The Scarecrow Press. Inc. 1993.

OTLET. PAUL Traité de Documentation: le livre sur le livre, théorie et pratique. Bruxelas: Mundaneum, 1934. Disponível em : <http://lib.ugent.be/fulltxt/handle/1854/5612/Traite_de_documentation_ocr.pdf >. Acesso em 25 fev. 2016

PAES, Marilena Leite. Arquivo: teoria e prática. 3. ed. Rio de Janeiro: Fundação Getúlio Vargas, 1991.

PEDERSON, Ann. Keeping archives. Sydney: Australian Society of Archivists, 1987.

POPPER. Karl. A lógica da pesquisa científica. Tradução Leonidas Hegenberg, Octanny Silveira da Mota. 2. ed. São Paulo: Cultrix, 2013.

RIDENER, John. From polders to postmodernism: a concise history of archival theory. 1. Ed. Minnesota: Litwin Books, 2009.

ROBREDO, Jaime. Da ciência da informação revisada aos sistemas humanos de informação. Brasília: Thesaurus, SSRR Informações, 2003.

Documentação de hoje e de amanhã. Brasília: Associação de Bibliotecários do Distrito Federal, 1978.

RODRIGUES, Samuel José Simon. O Princípio de Relatividade e o Problema da Objetividade Física. In: XVII Congresso Interamericano de Filosofia, 2013, Salvador. XVII Congresso Interamericano de Filosofia, 2013.

ROUSSEAU, Jean-Yves; COUTURE, Carol. Os fundamentos da disciplina arquivística. Lisboa: Publicações Dom Quixote, 1998.

RUIZ RODRÍGUEZ, Antônio Angel. Manual de archivística. Madrid: Sínteses, 2008.

SARACEVIC, Tefko. Ciência da informação: origem, evolução e relações. Perspectivas em Ciência da Informação, Belo Horizonte, v. 1, n. 1, p. 41-62, jan./jun. 1996.

SCHELLENBERG, T. R. Arquivos modernos: princípios e técnicas. 6. ed. Rio de Janeiro: Fundação Getúlio Vargas, 2006.

Documentos públicos e privados: arranjo e descrição. 2. ed. Rio de Janeiro: Fundação Getúlio Vargas, 1980.

SCHMIDT, Clarissa Moreira dos Santos. Arquivologia e a construção do seu objeto científico: concepções, trajetórias, contextualização. 2012. 320f. Tese (Doutorado) Escola de Comunicação e Artes. Universidade de São Paulo, São Paulo, 2012. 
SHANNON, Claude Elwood; WEAVER, Warren. The mathematical theory of communication. Urbana: University of Illinois Press, 1962.

SILVA, Armando Malheiro; RIBEIRO, Fernanda. Das "Ciências" Documentais à Ciência da Informação: ensaio epistemológico para um novo modelo curricular. 2. ed. Porto: Edições Afrontamento, 2008

SOCIETY OF AMERICAN ARCHIVIST. Canadian studies and the rediscovery of provanance. Canada: Society of Amercian Arqchivist, 1993.

SOUSA, R. T. B. Os princípios arquivísticos e o conceito de classificação. In: RODRIGUES, Georgete Medleg; LOPES, Ilza Leite. (Org.). Organização e representação do conhecimento na perspectiva da Ciência da Informação. Brasília: Thesaurus, 2003, v. 2, p. 240-269.

TAMBLÉ, Donato. La teoria archivistica italiana contemporanea: profilo storico critico (1950-1990). Roma: Grafiche Editoriali, 1993.

TANODI, Aurelio. Manual de archivología hispanoamericana: teorías y principios. Córdoba: Universidad Nacional, 1961.

TOGNOLI, Natália Bolfarini. A contribuição epistemológica canadense para a construção da Arquivística Contemporânea. 2010. 120 f. Dissertação (Mestrado em Ciência da Informação) - Faculdade de Filosofia e Ciências, Universidade Estadual Paulista, Marília, 2010.

TRIGUEIRO, Michelangelo Giotto Santoro. Ciência, verdade e sociedade: contribuições para um diálogo entre Sociologia e a Filosofia da Ciência. Belo Horizonte: Fabrefactum, 2012.

VÁZQUEZ, Manuel. Manual de Selección Documental. 1982. 2. ed. Córdoba: Escuela de Archiveros Universidad Nacional de Córdoba, 1995.

VICKERY, B. C. Classification and indexing in Science. 3. ed. London: Butterworths, 1975.

WEBER, Max. A “objetividade" do conhecimento nas ciências sociais. Tradução Gabriel Cohn. São Paulo: Ática, 2006.

WERNER, Michael; ZIMMERMANN, Bénédicte. Pensar a História Cruzada: entre a empiria e a reflexividade. Textos de História, Brasília, v. 11, n. 1/2, 2003.

WERSIG, G., NEVELING, U. Os fenômenos de interesse para a Ciência da Informação. The Information Scientist. v. 9, n. 4, 1996.

WIERSUM, E. Principle de la provenance dans le classement des Archives. In: Congrès de Bruxelles, 1910, Bruxelas. Congrès de Bruxelles - Congrès International des Archivistes et des Bibliothécaires, 1910. Disponível em: $<$ https://archive.org/stream/BrusselsCongress 1910/brussels_congress_1910\#page/n0/mo de/2up>. Acesso em: 12 dez. 2014. 
YEO, Geoffery. Debate about description. In: EASTWOOD, Terry; MACNEIL, Heather (Org.). Currents of Archival Thinking. Santa Barbara: Libraries Unlimited (Santa Barbara - United States), 2010. 
ANEXO A - Manuais Arquivísticos Internacionais

\begin{tabular}{|c|c|c|}
\hline AUTOR & OBRA & ANO \\
\hline $\begin{array}{l}\text { MULLER, S.; FEITH, J. A.; } \\
\text { FRUIN, R. }\end{array}$ & $\begin{array}{l}\text { Handleiding voor het ordenen en } \\
\text { bescrhreijven van archiven } \\
\text { (Manual de Arranjo e descrição de } \\
\text { arquivos -Manual dos Arquivistas } \\
\text { Holandeses) }\end{array}$ & 1898 \\
\hline JENKINSON, Hilary & A Manual of archive administration & 1922 \\
\hline CASANOVA, Eugenio & Archivistica & 1928 \\
\hline KONARSKI, Kazimierz & $\begin{array}{l}\text { Nowozytna archiwistyka polska i jej } \\
\text { zadania } \\
\text { (Contemporary Polish Archive Science } \\
\text { and its Tasks) }\end{array}$ & 1929 \\
\hline $\begin{array}{c}\text { DOLGIKH , F.I.; RUDELSON , } \\
\text { K.I. (Eds.) }\end{array}$ & $\begin{array}{c}\text { Teoría i praktika arhivnogo delà v SSSR } \\
\text { (Theory and practice of archival work } \\
\text { in the USSR) }\end{array}$ & 1946 \\
\hline BRENNEKE, Adolf & $\begin{array}{c}\text { Archivkunde: ein Betrag zur Theorie } \\
\text { und Geschichte des Europäuschen } \\
\text { Archivwesens } \\
\text { (Archives: a contribution to the theory } \\
\text { and history of European Archives) }\end{array}$ & 1953 \\
\hline SCHELLENBERG, Theodore & $\begin{array}{c}\text { Modern archives: principles and } \\
\text { techniques }\end{array}$ & 1956 (Ingla-terra) \\
\hline COLLINGRIDGE, J. H. & Le triage des archives & 1956 (Itália) \\
\hline CASSESE, Leopoldo & $\begin{array}{l}\text { Introduzione allo studio } \\
\text { dell'archivistica }\end{array}$ & 1959 \\
\hline SCHELLENBERG, T. R. & La importancia de los archivos & 1959 (Bolívia) \\
\hline MATILLA TASCÓN, Antonio & Cartilla de organización de archivos & 1960 \\
\hline TANODI, Aurélio & $\begin{array}{c}\text { Manual de Archivologia } \\
\text { Hispanoamericana: terias e princípios }\end{array}$ & 1961 \\
\hline BAUTIER, Robert-Henri & Les archives & 1961 \\
\hline SCHELLENBERG, T. R. & Técnicas descriptivas de archivos & 1961 \\
\hline SCHELLENBERG, T. R. & Princípios archivísticos de ordenación & 1961 (Washington) \\
\hline SCHELLENBERG, T. R. & $\begin{array}{c}\text { Public and private records: their } \\
\text { arrangement and description }\end{array}$ & 1963 \\
\hline SÁNCHEZ BELDA, Luís & $\begin{array}{c}\text { Bibliografía de Archivos españoles y de } \\
\text { Archivística }\end{array}$ & 1963 \\
\hline PEROTIN, Yves & $\begin{array}{c}\text { El concepto de archivo y las fronteras } \\
\text { archivísticas }\end{array}$ & $\begin{array}{c}1963 \\
\text { (Paris) }\end{array}$ \\
\hline POSNER, Ernst & American State Archives & 1964 \\
\hline SCHELLENBERG, Theodore & The management of archives & 1965 \\
\hline- & $\begin{array}{l}\text { Archivni prirucka } \\
\text { (Archives Manual) }\end{array}$ & 1965 \\
\hline DUCHEIN, Michel & $\begin{array}{c}\text { Les bâtiments d'archives, construction } \\
\text { et équipements }\end{array}$ & 1966 \\
\hline PEROTIN, Yves & Manuel d'archivistique tropicale & 1966 \\
\hline ENDERS, Gerhard & Archivverwaltungslehre & 1967 \\
\hline TANODI, Aurélio & Guia de los archivos de Córdoba & 1968 \\
\hline
\end{tabular}




\begin{tabular}{|c|c|c|}
\hline AUTOR & OBRA & ANO \\
\hline SANDRI, Leopoldo & La storia degli archivi & 1968 \\
\hline BENEDON, William & Records management & 1969 \\
\hline CENCETTI, Giorgio & Scriti archivistici & 1970 \\
\hline $\begin{array}{c}\text { ASSOCIATION DES } \\
\text { ARCHIVISTES FRANÇAIS }\end{array}$ & $\begin{array}{c}\text { Manuel d'archivistique: théorie et } \\
\text { pratique des archives publiques en } \\
\text { France }\end{array}$ & 1970 \\
\hline LAROCHE, Carlo & $\begin{array}{c}\text { Que signifie Le respect des fonds? } \\
\text { Esquisse d'une Archivistique } \\
\text { structurale }\end{array}$ & 1971 \\
\hline BOOMS, Hans & $\begin{array}{l}\text { Society and the formation of a } \\
\text { documentary heritage: issues in the } \\
\text { appraisal of Archival sources }\end{array}$ & 1972 \\
\hline NILSSON, Nils & $\begin{array}{c}\text { Arkivkunskap } \\
\text { (Learning archives) }\end{array}$ & 1973 \\
\hline VILFAN, Sergii; ZONTAR, Joze & Arhivistika & 1973 \\
\hline SAMARAN, Charles & $\begin{array}{c}\text { L'Histoire et ses methods: recherche, } \\
\text { conservation et critique des } \\
\text { témoignages }\end{array}$ & 1973 \\
\hline FRANZ, Eckhard G. & $\begin{array}{l}\text { Einfuihrung in der Archivkunde } \\
\text { (Introduction to the Archives) }\end{array}$ & 1974 \\
\hline OLIER, J. H.; DELMAS, Bruno & $\begin{array}{c}\text { La planification des infrastructures } \\
\text { nationales de documentation, de } \\
\text { bibliothèques et d'archives: esquisse } \\
\text { d'une politique générale }\end{array}$ & 1974 \\
\hline DUBOSCQ, Guy; MABBS, A. W. & Organisation du préarchivage & 1974 \\
\hline DUCKETT, Kenneth W. & $\begin{array}{c}\text { Modern manuscripts: a practical } \\
\text { manual for their management, care and } \\
\text { use }\end{array}$ & 1975 \\
\hline LEISINGER, Albert & La microphotography aux archives & 1975 \\
\hline PAPRITZ, Johannes & $\begin{array}{l}\text { Archivwissenschaft } \\
\text { (Archival Science) }\end{array}$ & 1976 \\
\hline DUCHEIN, Michel & Archives buildings and equipament & 1977 \\
\hline COOK, Michael & $\begin{array}{c}\text { Archives administration: a manual for } \\
\text { intermediate and smaller organizations } \\
\text { and for local government }\end{array}$ & 1977 \\
\hline GRACY II, David B. & $\begin{array}{c}\text { Archives \& manuscripts: arrangement } \\
\text { and description }\end{array}$ & 1977 \\
\hline FLECKNER, John & Archives \& manuscripts: surveys & 1977 \\
\hline BRICHFORD, Maynard T. & $\begin{array}{c}\text { Archives \& manuscripts: appraisal and } \\
\text { accessioning }\end{array}$ & 1977 \\
\hline HOLBERT, Sue E. & $\begin{array}{c}\text { Archives \& manuscripts: reference and } \\
\text { access }\end{array}$ & 1977 \\
\hline WALCH, Timothy & Archives \& manuscripts: security & 1977 \\
\hline $\begin{array}{c}\text { SOCIETY OF AMERICAN } \\
\text { ARCHIVISTS }\end{array}$ & Basic Manual Series I and II & 1977 \\
\hline CZESLAW, Biernat & $\begin{array}{c}\text { Problemy archiwistyki wzpolczesnej } \\
\text { Podrecenik } \\
\text { (Problems of Modern Archive Science) }\end{array}$ & 1977 \\
\hline
\end{tabular}




\begin{tabular}{|c|c|c|}
\hline AUTOR & OBRA & ANO \\
\hline $\begin{array}{c}\text { Savez Drustava Arhivskih Radnika } \\
\text { Jugoslavije } \\
\text { (União das Sociedades de } \\
\text { Arquivistas da Iugoslávia) }\end{array}$ & $\begin{array}{l}\text { Prirucnik iz arhivistike (Manual on } \\
\text { archive administration) }\end{array}$ & 1977 \\
\hline- & Arhivska tehnika (Archival Technique) & 1977 \\
\hline MEURLING, Anna Christina & $\begin{array}{c}\text { Arkivhandboken } \\
\text { (Handbook on archives) }\end{array}$ & 1977 \\
\hline MIJLAND, H. J. M. & $\begin{array}{l}\text { Documentkennis der financíele } \\
\text { administrate in hoofdzaak van 19e en } \\
\text { vroeg 20e eeuwse } \\
\text { (Knowledge of financial document } \\
\text { mainly administrative records of 19th } \\
\text { and early 20th century) }\end{array}$ & 1978 \\
\hline CORTÉS ALONSO, Vicenta & $\begin{array}{l}\text { Archivos de España y América: } \\
\text { materiales para un manual }\end{array}$ & 1979 \\
\hline BELL, L.; FAYE, B. & $\begin{array}{l}\text { La conception des bâtiments d'archives } \\
\text { en pays tropical }\end{array}$ & 1979 \\
\hline $\begin{array}{l}\text { CHABORD, Marie-Thérèse; } \\
\text { COUGNENC, Marguerite }\end{array}$ & $\begin{array}{l}\text { Les archives des administrations } \\
\text { centrales, conseils pratiques }\end{array}$ & 1979 \\
\hline ANTONIELLA, Augusto & $\begin{array}{l}\text { L'archivio comunale postunitario. } \\
\text { Contributo all'ordinamento degli } \\
\text { archivi dei comuni }\end{array}$ & 1979 \\
\hline $\begin{array}{l}\text { DUCHARME, Jacques; } \\
\text { ROUSSEAU, Jean-Yves }\end{array}$ & $\begin{array}{c}\text { L'interdependence des archives et de la } \\
\text { gestion des documents: une approche } \\
\text { globale de l'archivistique }\end{array}$ & 1980 \\
\hline HEREDIA HERRERA, Antonia & $\begin{array}{l}\text { Manual de organización de fondos de } \\
\text { Corporaciones Locales. El Archivo de } \\
\text { la Diputación Provincial de Sevilla }\end{array}$ & 1980 \\
\hline CORTÉS ALONSO, Vicenta & Documentación y Documentos & 1980 \\
\hline CASTERLINE, Gail Farr & Arquives \& manuscripts: exhibits & 1980 \\
\hline GUERIN-BROT, Isabelle & $\begin{array}{c}\text { Les archives des enterprises: conseils } \\
\text { pratiques d'organisation }\end{array}$ & 1980 \\
\hline LODOLINI, Elio & $\begin{array}{c}\text { Organizzazione e legislazione } \\
\text { archivistica italiana }\end{array}$ & 1980 \\
\hline DOLGICH, F. I.; RUDEL, K. I. & $\begin{array}{l}\text { Teoria I praktika archivnogo dela } v \\
\text { SSSR: Ucebnik } \\
\text { (Archival theory and practice in the } \\
\text { USSR) }\end{array}$ & 1980 \\
\hline \multirow{2}{*}{ TAYLOR, Hugh } & $\begin{array}{c}\text { The arrangement and description of } \\
\text { archival materials }\end{array}$ & 1980 \\
\hline & $\begin{array}{l}\text { Information ecology and the archives of } \\
\text { the 1980s }\end{array}$ & 1984 \\
\hline $\begin{array}{l}\text { DISPUTACION PROVINCIAL DE } \\
\text { SEVILLA }\end{array}$ & Archivística: estudios básicos & 1981 \\
\hline HICKERSON, H. Thomas & $\begin{array}{l}\text { Archives \& manuscripts: an } \\
\text { introduction to automated access }\end{array}$ & 1981 \\
\hline CONTINOLO, Giuseppe & El archivo en la organización moderna & 1981 \\
\hline CHAULEUR, Andrée & $\begin{array}{c}\text { Bibliothèque et archives: comment se } \\
\text { documenter? }\end{array}$ & 1981 \\
\hline
\end{tabular}




\begin{tabular}{|c|c|c|}
\hline $\begin{array}{c}\text { AUTOR } \\
\end{array}$ & OBRA & ANO \\
\hline $\begin{array}{l}\text { MINISTĖRE DE L'EDUCATION } \\
\text { NATIONALE }\end{array}$ & $\begin{array}{l}\text { Les archives des administrations: } \\
\text { conseils pratiques }\end{array}$ & 1981 \\
\hline ( & $\begin{array}{l}\text { Metodicheski kodeks } \\
\text { (Methodical Manual) }\end{array}$ & 1982 \\
\hline CORTÉS ALONSO, Vicenta & Manual de archivos municipales & 1982 \\
\hline HEREDIA HERRERA, Antonia & $\begin{array}{c}\text { Manual de instrumentos de descripción } \\
\text { documental }\end{array}$ & 1982 \\
\hline CIGREF & L'archivage électronique & 1982 \\
\hline $\begin{array}{c}\text { SERVICE CENTRAL } \\
\text { D'ORGANISATION ET } \\
\text { MÉTHODES }\end{array}$ & $\begin{array}{l}\text { La function archives dans les services } \\
\text { administratifs publics et privés }\end{array}$ & 1982 \\
\hline $\begin{array}{l}\text { COUTURE, Carol; ROUSSEAU, } \\
\text { Jean-Yves }\end{array}$ & $\begin{array}{l}\text { Les archives au XXe siècle: une réponse } \\
\text { aux besoins de l'administration et de la } \\
\text { recherche }\end{array}$ & 1982 \\
\hline $\begin{array}{l}\text { PETERSON, Ann E.; } \\
\text { CASTERLINE, Gail Farr }\end{array}$ & $\begin{array}{c}\text { Archives \& manuscripts: public } \\
\text { programs }\end{array}$ & 1982 \\
\hline EHRENBERG, Ralph E. & $\begin{array}{c}\text { Archives \& manuscripts: maps and } \\
\text { architectural drawings }\end{array}$ & 1982 \\
\hline SUNG, Carolyn Hoover & Archives \& manuscripts: reprography & 1982 \\
\hline VÁSQUEZ, Manuel & Manual de selección documental & 1982 \\
\hline $\begin{array}{l}\text { Folkrörelsernas arkivförbund, } \\
\text { Civildepartment }\end{array}$ & $\begin{array}{c}\text { Folkrôrelsernas arkivforbu } \\
\text { (Handbook for the archives of national } \\
\text { movements) }\end{array}$ & 1982 \\
\hline BERNER, Richard C. & $\begin{array}{l}\text { Archival Theory and practice in the } \\
\text { United States: a historical analysis }\end{array}$ & 1983 \\
\hline RITZANTHALER, Mary Lynn & Archives \& manuscripts: conservation & 1983 \\
\hline HENSEN, Steven & $\begin{array}{l}\text { Archives, personal paper and } \\
\text { manuscripts: a cataloguing manual for } \\
\text { archival repositories, historical } \\
\text { societies and manuscript libraries }\end{array}$ & 1983 \\
\hline $\begin{array}{l}\text { MATA CASTILLÓN, José Manuel; } \\
\text { NÚÑEZ CONTRERAS, Luis; } \\
\text { HEREDIA HERRERA, Antonia }\end{array}$ & Archivística: estúdios básicos & 1983 \\
\hline PIAZZALI, Luis & $\begin{array}{c}\text { Manual practico sobre técnicas } \\
\text { archivisticas }\end{array}$ & 1983 \\
\hline $\begin{array}{l}\text { FLIEDER, Françoise; DUCHEIN, } \\
\text { Michel }\end{array}$ & $\begin{array}{l}\text { Livres et documents d'archives: } \\
\text { sauvagarde et conservation }\end{array}$ & 1983 \\
\hline $\begin{array}{l}\text { COMITTEE ON BUSINESS } \\
\text { ARCHIVES OF ICA }\end{array}$ & $\begin{array}{c}\text { Business archives studies on } \\
\text { international practices }\end{array}$ & 1983 \\
\hline CARUCCI, Paola & $\begin{array}{c}\text { Le fonti archivistiche: ordinamento e } \\
\text { conservazione }\end{array}$ & 1983 \\
\hline HORSMAN, P. J.; SIGMOND, J. P. & $\begin{array}{c}\text { Het land van herkomsteen reader van } \\
\text { artikelen rond het herkomstbeginsel } \\
\text { (Origin reader of articles about the } \\
\text { origin principle) }\end{array}$ & 1983 \\
\hline STATE ARCHIVES SCHOOL & $\begin{array}{c}\text { Leidraad bij de lessen in het ordenen en } \\
\text { beschrijven van archieven } \\
\text { (Guide to the lessons in organizing and } \\
\text { describing archives) }\end{array}$ & 1983 \\
\hline
\end{tabular}




\begin{tabular}{|c|c|c|}
\hline AUTOR & OBRA & ANO \\
\hline BRACHMANN, Botho (org.) & $\begin{array}{c}\text { Archivwesen der Deutschen } \\
\text { Demokratischen Republik: theorie und } \\
\text { praxis } \\
\text { (Archives of the German Democratic } \\
\text { Republic: theory and practice) }\end{array}$ & 1984 \\
\hline HEREDIA HERRERA, Antonia & Archivística general: teoría y práctica & 1984 \\
\hline $\begin{array}{l}\text { PESCADOR DEL HOYO, Maria } \\
\text { del Carmen }\end{array}$ & El archivo: instrumentos de trabajo & 1984 \\
\hline HILDESHEIMER, Françoise & Les archives:porquoi? Comment? & 1984 \\
\hline HENDRIKS, Klaus B. & $\begin{array}{c}\text { The preservation and restoration of } \\
\text { photographic materials in archives and } \\
\text { libraries }\end{array}$ & 1984 \\
\hline LODOLINI, Elio & Archivistica: principi e problemi & 1984 \\
\hline $\begin{array}{c}\text { ARCHIVES AND RECORDS } \\
\text { SERVICE }\end{array}$ & $\begin{array}{c}\text { A modern archives reader: basic } \\
\text { readings on archival theory and } \\
\text { practice }\end{array}$ & 1984 \\
\hline PEACE, Nancy E. & $\begin{array}{c}\text { Archival choices: managing the } \\
\text { historical record in an age of } \\
\text { abundance }\end{array}$ & 1984 \\
\hline HEDSTROM, Margaret L. & $\begin{array}{c}\text { Archives \& Manuscripts: Machine- } \\
\text { Readable Records }\end{array}$ & 1984 \\
\hline $\begin{array}{l}\text { RITZENTHALER, Mary Lynn; } \\
\text { MUNOFF, Gerald J.; LONG, } \\
\text { Margery S. }\end{array}$ & $\begin{array}{c}\text { Archives \& Manuscripts: } \\
\text { administration of photographic } \\
\text { collections }\end{array}$ & 1984 \\
\hline VINOGRADOV, V. M. et al & $\begin{array}{l}\text { Theoretical problems of archive } \\
\text { maintenance from the stand-point of } \\
\text { information science }\end{array}$ & 1984 \\
\hline $\begin{array}{l}\text { GLAVNOE ARHIVNOE } \\
\text { UPRAVLENIE PRI SOVETE } \\
\text { MINISTROV SSSR }\end{array}$ & $\begin{array}{c}\text { Osnovnye pravila roboty } \\
\text { gosudartsvennyh arhivov SSSR } \\
\text { (Basic working rules of the state } \\
\text { archives in the USSR) }\end{array}$ & 1984 \\
\hline ZONTAR, Joze & Archivistika & 1984 \\
\hline RASTAS , Pirkko & $\begin{array}{c}\text { Arkistotoimi ja asiakirjahallinto } \\
\text { (Archives administration and records } \\
\text { management) }\end{array}$ & 1984 \\
\hline CARDINAL, Louis et al & $\begin{array}{c}\text { Les instruments de recherche pour les } \\
\text { archives }\end{array}$ & 1984 \\
\hline BUCKLAND, Y. & Personnel Records & 1984 \\
\hline FAVIER, Jean & Les archives & 1985 \\
\hline $\begin{array}{c}\text { DURAND-ÉVRARD, Françoise; } \\
\text { DURAND, Claude }\end{array}$ & $\begin{array}{c}\text { Guide pratique à l'usage de } \\
\text { l'archiviste-documentaliste: un exemple } \\
\text { concret-les communes }\end{array}$ & 1985 \\
\hline GALLEGO DOMÍNGUEZ, Olga & Introducción a la arquivística & 1985 \\
\hline GIUFFRIDA, Romualdo & Antologia di Scritti Archivistici & 1985 \\
\hline $\begin{array}{l}\text { Glavnoe Arhivnoe Upravlenie Pri } \\
\text { Sovete Ministrov SSSR }\end{array}$ & $\begin{array}{c}\text { Osnovnye pravila roboty s naucno-... } \\
\text { (Basic working rules with the scientific- } \\
\text { technical documentation in the state } \\
\text { archives in the USSR) }\end{array}$ & 1985 \\
\hline
\end{tabular}




\begin{tabular}{|c|c|c|}
\hline AUTOR & OBRA & ANO \\
\hline $\begin{array}{c}\text { PROCTER, Margaret; COOK, } \\
\text { Michael }\end{array}$ & $\begin{array}{l}\text { The manual of archival description: } \\
\text { recent research in archival description } \\
\text { in the United Kingdom }\end{array}$ & $1985 / 1986$ \\
\hline MC CRANK, L. J. & $\begin{array}{c}\text { Archives and library administration. } \\
\text { divergent traditions and common } \\
\text { concerns }\end{array}$ & 1986 \\
\hline STIELOW, Frederick J. & $\begin{array}{c}\text { The management of oral History Sound } \\
\text { Archives }\end{array}$ & 1986 \\
\hline COOK, Michael & $\begin{array}{c}\text { The management of information from } \\
\text { archives }\end{array}$ & 1986 \\
\hline COOK, Michael & $\begin{array}{l}\text { Guidelines on curriculum development } \\
\text { in information technology for } \\
\text { librarians, documentalist and archivists }\end{array}$ & 1986 \\
\hline $\begin{array}{l}\text { COOK, Michael; PROCTER, } \\
\text { Margaret }\end{array}$ & $\begin{array}{c}\text { A manual of Archival Description- } \\
\text { MAD } 2\end{array}$ & 1986 \\
\hline $\begin{array}{c}\text { BUREAU CANADIEN DES } \\
\text { ARCHIVISTES. }\end{array}$ & $\begin{array}{l}\text { Les normes de description en } \\
\text { Archivistique: une necessité }\end{array}$ & 1986 \\
\hline $\begin{array}{l}\text { DIRECTION DES ARCHIVES DE } \\
\text { FRANCE } \\
\end{array}$ & $\begin{array}{c}\text { Bâtiments d'archives. Vingt ans } \\
\text { d'architecture française. 1965-1985 }\end{array}$ & 1986 \\
\hline $\begin{array}{l}\text { GIESSEL, A.; KETELAAR, F. C. } \\
\text { J.; TEULLING, A. J. M. }\end{array}$ & $\begin{array}{c}\text { Archiefbeheer in practijk } \\
\text { (Records management in practice) }\end{array}$ & 1986 \\
\hline HORSMAN, P. J. & $\begin{array}{c}\text { Ordenen van archieven } \\
\text { (Organize archives) }\end{array}$ & 1986 \\
\hline KONSTANTINOV, Milos & Arhivistika & 1986 \\
\hline $\begin{array}{l}\text { BRUK, Ivanka; POPOVIC, } \\
\text { Ljubodrag }\end{array}$ & Arhivistika & 1986 \\
\hline MELLATT & $\begin{array}{c}\text { Les archives dans les administrations } \\
\text { centrales et les établissements publics: } \\
\text { l'esprit et les methods }\end{array}$ & 1987 \\
\hline MELLATT & $\begin{array}{c}\text { Les archives dans les services } \\
\text { extérieurs: l'esprit et les methods }\end{array}$ & 1987 \\
\hline HARRISON, Helen P. & $\begin{array}{l}\text { The archival appraisal of sound records } \\
\text { and related materials }\end{array}$ & 1987 \\
\hline $\begin{array}{l}\text { CHAMPAGNE, Michel; } \\
\text { CHOUINARD, Denys }\end{array}$ & $\begin{array}{l}\text { Le traitement d'un fonds d'archives: ses } \\
\text { documents historiques }\end{array}$ & 1987 \\
\hline $\begin{array}{c}\text { DRYDEN, Jean E.; HAWORTH, } \\
\text { Kent M. }\end{array}$ & $\begin{array}{l}\text { L'élaboration de normes de } \\
\text { description: appel à l'action }\end{array}$ & 1987 \\
\hline PEDERSON, Ann & Keeping archives & 1987 \\
\hline MARTHINSEN, Jorgen H. & $\begin{array}{c}\text { Arkivdanning. Veiledning i arkivarbeid } \\
\text { (Stock Formation. Guidance on } \\
\text { archival work) }\end{array}$ & 1987 \\
\hline STATE ARCHIVES SCHOOL & $\begin{array}{l}\text { Reader archivistiek en inventarisatie } \\
\text { (Reader archiving and inventory of the } \\
\text { strate) }\end{array}$ & 1987 \\
\hline COOK, Michael & Computer-generated records & 1987 \\
\hline $\begin{array}{l}\text { DIRECTION DES ARCHIVES DE } \\
\text { FRANCE } \\
\end{array}$ & $\begin{array}{l}\text { Recueils des lois et règlements relatifs } \\
\text { aux archives: } 1958-1988\end{array}$ & 1988 \\
\hline $\begin{array}{l}\text { CHAMBRE DE COMMERCE ET } \\
\text { D'INDUSTRIE DE PARIS }\end{array}$ & $\begin{array}{c}\text { Gérer, organiser vos archives, } \\
\text { mémoriser l'information interne }\end{array}$ & 1988 \\
\hline DUCHEIN, Michel & Archives buildings and equipment & 1988 \\
\hline
\end{tabular}




\begin{tabular}{|c|c|c|}
\hline AUTOR & OBRA & ANO \\
\hline ULFSPARRE, Anna Christina & The management of business records & 1988 \\
\hline EVANS, Frank B. & $\begin{array}{c}\text { Managing archives and archival } \\
\text { institutions }\end{array}$ & 1988 \\
\hline KESNER, Richard M. & $\begin{array}{l}\text { Information systems: a strategic } \\
\text { approach to planning and } \\
\text { implementation }\end{array}$ & 1988 \\
\hline SCHIE, H. A. J. van & $\begin{array}{c}\text { Registratuur van de Nederlandse } \\
\text { overheidsadministratie in de } \\
\text { negentiende eeuw } \\
\text { (Registrar Structure of the Dutch } \\
\text { government administration in the } \\
\text { nineteenth century) }\end{array}$ & 1988 \\
\hline RATSMA, P.; WILMER, C. C. S. & $\begin{array}{c}\text { Handleiding voor net beheer van een } \\
\text { topografish-historische atlas } \\
\text { (Guide to managing a network } \\
\text { topografish-historical atlas) }\end{array}$ & 1988 \\
\hline $\begin{array}{l}\text { BUCHANAN, Sally A.; } \\
\text { MURRAY, Toby }\end{array}$ & $\begin{array}{l}\text { Disaster planning, preparedness and } \\
\text { recovery for libraries and archives }\end{array}$ & 1988 \\
\hline PARKER, Thomas A. & $\begin{array}{l}\text { Study on integrated pest management } \\
\text { for libraries and archives }\end{array}$ & 1988 \\
\hline $\begin{array}{c}\text { Archivna Sprava Ministerstva } \\
\text { Vnutra SSR } \\
\text { (Arquivos do Ministério da } \\
\text { Administração Interna SSR) }\end{array}$ & $\begin{array}{c}\text { Qchrana. spristupnovanie a vyuzivanie } \\
\text { archivnych documentov } \\
\text { (Preservation, access to archives and } \\
\text { the used of archives documents) }\end{array}$ & 1988 \\
\hline NORDBERG, Axel & $\begin{array}{c}\text { Arkivera ratt } \\
\text { (Filing in the right way') }\end{array}$ & 1988 \\
\hline $\begin{array}{l}\text { CAMPHAUSEN, Walter; } \\
\text { REXHEUSER, Rex }\end{array}$ & $\begin{array}{c}\text { Ostdeutsche archivalische Sammlungen. } \\
\text { Einlteitfaden fiir Erschliessung und } \\
\text { Aufbewahrung } \\
\text { (East German archival collections) }\end{array}$ & 1989 \\
\hline $\begin{array}{c}\text { LOPEZ GOMEZ, Pedro; } \\
\text { GALLEGO DOMINGUEZ, Olga }\end{array}$ & Introduccion a la Archivista & 1989 \\
\hline $\begin{array}{l}\text { ROBOTKA, Halina; RYSZEWSKI, } \\
\text { Bohdan; TOMCZAK, Andrzej }\end{array}$ & Archiwistyka & 1989 \\
\hline GARLAND, $\mathrm{S}$ & Financial records & 1989 \\
\hline EMMERSON, Peter & $\begin{array}{l}\text { How to manage your records: a guide } \\
\text { to effective practice }\end{array}$ & 1989 \\
\hline $\begin{array}{l}\text { PENN, Ira A .; MORDDEL , Anne; } \\
\text { PENNIX, Gail; SMITH, Kelvin }\end{array}$ & Records Management Handbook & 1989 \\
\hline $\begin{array}{c}\text { ROTZSCH, Helmuth; WACHTER, } \\
\text { Wolfgang }\end{array}$ & $\begin{array}{c}\text { Study on mass conservation techniques } \\
\text { for treatment of library and archives } \\
\text { material }\end{array}$ & 1989 \\
\hline KEENE, James A. & Manual of archival reprography & 1989 \\
\hline $\begin{array}{c}\text { GLAVNOE ARHIVNOE } \\
\text { UPRAVLENIE PRI SOVETE } \\
\text { MINISTROV SSSR }\end{array}$ & $\begin{array}{l}\text { Pravila raboty gosudartsvennyh } \\
\text { rajonnyh i gorodskih arhivov } \\
\text { (Working rules of the state } \\
\text { regional and municipal archives') }\end{array}$ & 1989 \\
\hline DURANTI, Luciana & $\begin{array}{c}\text { Diplomatics: new uses for an old } \\
\text { Science }\end{array}$ & 1989 \\
\hline BAILEY, Catherine & Archival theory and electronic records & $1989-1990$ \\
\hline
\end{tabular}




\begin{tabular}{|c|c|c|}
\hline AUTOR & OBRA & ANO \\
\hline $\begin{array}{c}\text { BUREAU CANADIEN DES } \\
\text { ARCHIVISTES }\end{array}$ & Rules for archival description & 1990 \\
\hline O’TOOLE, James & $\begin{array}{c}\text { Understanding archives and } \\
\text { manuscripts }\end{array}$ & 1990 \\
\hline $\begin{array}{l}\text { WILSTED, Thomas; NOLTE, } \\
\text { William }\end{array}$ & $\begin{array}{c}\text { Managing Archival and Manuscript } \\
\text { Repositories }\end{array}$ & 1990 \\
\hline MILLER, Frederic M. & $\begin{array}{l}\text { Arranging and Describing Archives and } \\
\text { Manuscripts }\end{array}$ & 1990 \\
\hline ARCHIVES NATIONALES & $\begin{array}{l}\text { Le témoignage oral aux archives: de la } \\
\text { collecte à la communication }\end{array}$ & 1990 \\
\hline HILDESHEIMER, Françoise & $\begin{array}{c}\text { Les Archives privées: le traitement des } \\
\text { archives personnelles, familiales, } \\
\text { associatives }\end{array}$ & 1990 \\
\hline HILDESHEIMER, Françoise & $\begin{array}{l}\text { Les archives du notaire: de la } \\
\text { protection à la connaissance de l'intime }\end{array}$ & 1990 \\
\hline LAVEDRINE, Bertrand & La conservation des photographies & 1990 \\
\hline HORDER, Alan & $\begin{array}{c}\text { Guidelines for the care and } \\
\text { preservation of microforms in tropical } \\
\text { countries }\end{array}$ & 1990 \\
\hline CHAPMAN, Patricia & $\begin{array}{c}\text { Guidelines on preservation and } \\
\text { conservation policies in the archives } \\
\text { and libraries heritage }\end{array}$ & 1990 \\
\hline $\begin{array}{l}\text { Stiftung Deutsche Kinemathek } \\
\text { (Foundation German } \\
\text { Cinematheque) }\end{array}$ & $\begin{array}{l}\text { Curriculum development for the } \\
\text { training of personnel in moving image } \\
\text { and recorded sound archives }\end{array}$ & 1990 \\
\hline FRANZ, Eckhart G. & $\begin{array}{c}\text { Einfiihrung in die Archivkunde } \\
\text { (Introduction to the Archives) }\end{array}$ & 1990 \\
\hline $\begin{array}{l}\text { ASSOCIATION OF FINNISH } \\
\text { BUSINESS ARCHIVES; } \\
\text { HELASTI, H.; HYPPONEN, M. }\end{array}$ & $\begin{array}{l}\text { Arkistotoimen perusteet } \\
\text { (Basics of archival work) }\end{array}$ & 1990 \\
\hline WARD, Alan & Manual of sound archive administration & 1990 \\
\hline $\begin{array}{l}\text { FÉDÉRATION HOSPITALIÈRE } \\
\text { DE FRANCE }\end{array}$ & L'archivage & 1991 \\
\hline GAGNON-ARGUIN, Louise & $\begin{array}{l}\text { L'Archivistique: son histoire, ses } \\
\text { acteurs depuis } 1960\end{array}$ & 1992 \\
\hline EASTWOOD, Terry & $\begin{array}{l}\text { The archival fonds: from theory to } \\
\text { practice* }\end{array}$ & 1992 \\
\hline COUTURE, Carol (org.) & $\begin{array}{c}\text { La normalization en Archivistique: un } \\
\text { pas de plus dan l'évolution d'une } \\
\text { discipline }\end{array}$ & 1992 \\
\hline ROBERGE, Michel & $\begin{array}{c}\text { La gestion de l'information } \\
\text { administrative: application globale, } \\
\text { systémique et systématique }\end{array}$ & 1992 \\
\hline $\begin{array}{l}\text { CONDE VILLAVERDE, María } \\
\text { Luisa }\end{array}$ & $\begin{array}{l}\text { Manual de tratamiento de archivos } \\
\text { administrativos }\end{array}$ & 1992 \\
\hline CRUZ MUNDET, J. R. & $\begin{array}{l}\text { Archivos Municipales de Euskadi: } \\
\text { Manual de organización }\end{array}$ & 1992 \\
\hline $\begin{array}{l}\text { DIRECTION DES ARCHIVES DE } \\
\text { FRANCE } \\
\end{array}$ & La pratique archivistique française & 1993 \\
\hline
\end{tabular}




\begin{tabular}{|c|c|c|}
\hline AUTOR & OBRA & ANO \\
\hline $\begin{array}{c}\text { SOCIETY OF AMERICAN } \\
\text { ARCHIVISTS / ASSOCIATION } \\
\text { OF CANADIAN ARCHIVISTS }\end{array}$ & $\begin{array}{l}\text { Canadian archival studies and the } \\
\text { rediscovery of provenance }\end{array}$ & 1993 \\
\hline TAMBLÉ, Donato & $\begin{array}{c}\text { La teoria archivistica italiana } \\
\text { contemporanea: profile storico critico } \\
(1950-1990)\end{array}$ & 1993 \\
\hline GALLEGO DOMÍNGUEZ, Olga & Manual de archivos familiares & 1993 \\
\hline LODOLINI, Elio & Archivística: principios y problemas & 1993 \\
\hline LÓPEZ GUTIÉRREZ, A. J. & $\begin{array}{l}\text { Los Archivos de las hermandades } \\
\text { religiosas. Manual de organización de } \\
\text { fondos }\end{array}$ & 1993 \\
\hline $\begin{array}{l}\text { ROUSSEAU, Jean-Yves; } \\
\text { COUTURE, Carol }\end{array}$ & $\begin{array}{l}\text { Les fondements de la discipline } \\
\text { archivistique }\end{array}$ & 1994 \\
\hline $\begin{array}{c}\text { MCKEMMISH Sue; PIGGOTT, } \\
\text { Michael; REED, Barbara. } \\
\text { UPWARD, Frank } \\
\end{array}$ & $\begin{array}{l}\text { The records continuum: Ian Maclean } \\
\text { and Australian Archives first fifty years }\end{array}$ & 1994 \\
\hline CRUZ MUNDET, José Ramón & Manual de Archivística & 1994 \\
\hline CARUCI, Paola et al & $\begin{array}{l}\text { Documento y archivo de gestión: } \\
\text { diplomática de ahora mismo }\end{array}$ & 1994 \\
\hline $\begin{array}{l}\text { RUIZ RODRÍGUEZ, Antonio } \\
\text { Ángel }\end{array}$ & Manual de Archivística & 1995 \\
\hline $\begin{array}{l}\text { MARTIN-POZUELO } \\
\text { CAMPILLOS, M. Paz }\end{array}$ & $\begin{array}{c}\text { La construcción teórica en Archivística: } \\
\text { el principio de procedencia }\end{array}$ & 1996 \\
\hline MOLINA NORTES, Juana & $\begin{array}{c}\text { Técnicas de archivo y tratamiento de la } \\
\text { documentación administrativa }\end{array}$ & 1996 \\
\hline LÓPEZ YEPES, José & $\begin{array}{c}\text { Manual de información y } \\
\text { documentación }\end{array}$ & 1996 \\
\hline LODOLINI, Elio & $\begin{array}{c}\text { Lineamenti di storia dell'archivistica } \\
\text { italiana: dalle origini alla metà del } \\
\text { secolo } X X\end{array}$ & 1996 \\
\hline DUPLÁ DEL MORAL, Ana & $\begin{array}{l}\text { Manual de Archivos de Oficina para } \\
\text { Gestores. Comunidad de Madrid }\end{array}$ & 1997 \\
\hline FERNÁNDEZ GIL, Paloma & $\begin{array}{l}\text { Manual de organización de archivos de } \\
\text { gestión en las oficinas municipales }\end{array}$ & 1997 \\
\hline CERDÁ DÍAZ, Julio & $\begin{array}{l}\text { Los archivos municipales en la España } \\
\text { contemporánea }\end{array}$ & 1997 \\
\hline $\begin{array}{c}\text { GENERELO, Juan José; LÓPEZ, } \\
\text { Ángeles Moreno (org.) }\end{array}$ & $\begin{array}{c}\text { Historia de los archivos y de la } \\
\text { Archivistica en España }\end{array}$ & 1998 \\
\hline CRUZ MUNDET, José Ramón & $\begin{array}{c}\text { Información y Documentación } \\
\text { Administrativa }\end{array}$ & 1998 \\
\hline NÚÑEZ FERNÁNDEZ, Eduardo & Organización y gestión de archivos & 1999 \\
\hline ALBERCH FUGUERAS, Ramón & $\begin{array}{c}\text { Archívese! Los documentos del poder. } \\
\text { El poder de los documentos }\end{array}$ & 1999 \\
\hline SANCHIS MORENO, Francisco & $\begin{array}{l}\text { Los archivos de oficina: una sintesis } \\
\text { para su gestión }\end{array}$ & 1999 \\
\hline SASTRE SANTOS, Eutimio & $\begin{array}{c}\text { Manual de archivos. El sistema } \\
\text { archivístico diocesano: archivos de la } \\
\text { curia y archivos parroquiales }\end{array}$ & 1999 \\
\hline
\end{tabular}




\begin{tabular}{|c|c|c|}
\hline AUTOR & OBRA & ANO \\
\hline $\begin{array}{c}\text { CRUZ HERRANZ, Luis Miguel de } \\
\text { la }\end{array}$ & $\begin{array}{l}\text { Bibliografía archivítica española } \\
\text { [recurso electrónico]: 1962-2000 }\end{array}$ & 2000 \\
\hline
\end{tabular}

Fonte: Marques (2011). 
ANEXO B - Manuais Arquivísticos Nacionais

\begin{tabular}{|c|c|c|c|}
\hline AUTOR & OBRA & ANO & (RE)EDIÇÃO \\
\hline & Projeto Rondon: operação Arquivo & 1974 & \\
\hline & $\begin{array}{l}\text { Diagnóstico sobre a aplicação do sistema de arranjo Boullier } \\
\text { de Branche do Arquivo Nacional }\end{array}$ & 1983 & \\
\hline & $\begin{array}{l}\text { Uma política de arranjo documental para a Universidade } \\
\text { Federal de Santa Maria }\end{array}$ & 2001 & \\
\hline & Leituras cartográficas históricas e contemporâneas & 2003 & \\
\hline ALMEIDA, Luíz Fernando Duarte de & $\begin{array}{l}\text { Ensaios de sistemas de informação em arquivologia \& } \\
\text { documentação }\end{array}$ & 1986 & 4.ed. \\
\hline ALMEIDA, Luíz Fernando Duarte de & Administração de arquivos e documentos & 1987 & \\
\hline ARQUIVO DO ESTADO DE SÃO PAULO & $\begin{array}{l}\text { Diagnóstico da situação dos arquivos do governo do Estado } \\
\text { de São Paulo: órgãos da administração direta sediados na } \\
\text { Capital }\end{array}$ & 1987 & \\
\hline ARQUIVO DO ESTADO DE SÃO PAULO & Manual de procedimentos para tratamento documental & 1998 & \\
\hline ARQUIVO NACIONAL (Brasil) & Cadastro Nacional de Arquivos Federais & 1990 & \\
\hline ARQUIVO NACIONAL (BRASIL) & $\begin{array}{l}\text { Levantamento sobre arquivos impressos para discussão } \\
\text { técnica }\end{array}$ & $198 ?$ & \\
\hline ARQUIVO PÚBLICO DO DISTRITO FEDERAL & Diagnóstico dos arquivos do governo do Distrito Federal & 1990 & \\
\hline $\begin{array}{l}\text { ARQUIVO PÚBLICO ESTADUAL (Rio Grande do Norte) ; REGO, Vanilde } \\
\text { de Souza }\end{array}$ & $\begin{array}{l}\text { Implantação do Sistema Estadual de Arquivo - Rio Grande } \\
\text { do Norte }\end{array}$ & 1979 & \\
\hline BELLOTTO, Heloisa Liberalli & Arquivos permanentes: tratamento documental & 1991 & \\
\hline BELLOTTO, Heloisa Liberalli & $\begin{array}{l}\text { Como fazer análise diplomática e análise tipológica de } \\
\text { documentos de arquivo (Projeto Como fazer, 8) }\end{array}$ & 2002 & \\
\hline BELLOTTO, Heloisa Liberalli & Diplomática e tipologia documental em arquivos & 2008 & 2.ed.rev.e ampl. \\
\hline BERTOLETTI, Esther Caldas & $\begin{array}{l}\text { Como fazer programas de reprodução de documentos de } \\
\text { arquivo (Como Fazer, 7) }\end{array}$ & 2002 & \\
\hline $\begin{array}{l}\text { BRASIL. Ministério do Planejamento e Coordenação Geral; BRASIL. } \\
\text { Ministério da Justiça }\end{array}$ & $\begin{array}{l}\text { Assistência técnica para a modernização administrativa do } \\
\text { Arquivo Nacional: qualificação técnica }\end{array}$ & 1974 & \\
\hline
\end{tabular}




\begin{tabular}{|c|c|c|c|}
\hline BRASIL. Tribunal Superior Eleitoral & Acervo arquivístico: descrição & 2008 & 2009 \\
\hline CASSARES, Norma Cianflone; MOI, Cláudia (Col.) & $\begin{array}{l}\text { Como fazer conservação preventiva em arquivos e } \\
\text { bibliotecas }\end{array}$ & 2000 & \\
\hline $\begin{array}{l}\text { CASTANHO, Denise Molon (Ed.); PERES, Rosanara Urnanetto (Ed.); } \\
\text { UNIVERSIDADE FEDERAL DE SANTA MARIA; RICHTER, Eneida } \\
\text { Izabel Schirmer }\end{array}$ & Caderno de Arquivologia & 2002 & 2005 \\
\hline $\begin{array}{l}\text { CASTANHO, Denise Molon; RICHTER, Eneida Izabel Schirmer; GARCIA, } \\
\text { Olga Maria Correa }\end{array}$ & $\begin{array}{l}\text { Curso de Arquivologia da Universidade Federal de Santa } \\
\text { Maria: } 25 \text { anos de história: } 1977-2002\end{array}$ & 2002 & \\
\hline CASTILHO, Ataliba Teixeira de (Coord.) & A sistematização de arquivos públicos & 1991 & \\
\hline $\begin{array}{l}\text { CASTRO, Astréa de Moraes e Arquivo no Brasil e na Europa } 1973 \text { CASTRO, } \\
\text { Astréa de Moraes e; CASTRO, Andresa de Moraes e; GASPARIAN, Danuza } \\
\text { de Moraes e Castro }\end{array}$ & Arquivos: físicos e digitais & 2007 & \\
\hline CASTRO, Astréa de Moraes e; GASPARIAN, Danuza de Moraes e Castro & Arquivística $=$ Técnica, arquivologia $=$ ciência & 1985 & 1988 \\
\hline $\begin{array}{l}\text { CENTRO DE PESQUISA E DOCUMENTAÇÃO DE HISTÓRIA } \\
\text { CONTEMPORÂNEA DO BRASIL }\end{array}$ & Procedimentos técnicos em arquivos privados & 1986 & \\
\hline CONSELHO NACIONAL DE ARQUIVOS (Brasil) & $\begin{array}{l}\text { Classificação, temporalidade e destinação de documentos de } \\
\text { arquivo relativos às atividadesmeio da administração } \\
\text { pública }\end{array}$ & 2001 & \\
\hline CONSELHO NACIONAL DE ARQUIVOS (Brasil) & $\begin{array}{l}\text { Subsídios para a implantação de uma política municipal de } \\
\text { arquivos: o arquivo municipal a serviço dos cidadãos }\end{array}$ & s. d. & \\
\hline CONWAY, Paul; BECK, Ingrid (Coord.)* & $\begin{array}{l}\text { Preservação no universo digital (Projeto conservação } \\
\text { preventiva em bibliotecas e arquivos,52) }\end{array}$ & 1997 & \\
\hline DIVISÃO DE ARQUIVO DO ESTADO (São Paulo) & $\begin{array}{l}\text { Arquivos do governo do Estado de São Paulo: problemas e } \\
\text { soluções }\end{array}$ & 1977 & \\
\hline ESPOSEL, José Pedro Pinto & Noções prévias para elaboração de um manual de arquivo & 1975 & \\
\hline ESPOSEL, José Pedro Pinto & Arquivos: uma questão de ordem & 1994 & \\
\hline $\begin{array}{l}\text { FILIPPI, Patrícia de; LIMA, Solange Ferraz de; CARVALHO, Vânia } \\
\text { Carneiro de }\end{array}$ & Como tratar coleções de fotografias (Como Fazer, 4) & 2002 & 2.ed. \\
\hline FRANQUEIRA, Ana; GARCIA, Madalena; ANTONIO, Rafael & $\begin{array}{l}\text { ARQBASE: metodologia de descrição arquivística para } \\
\text { tratamento automatizado de } 1989\end{array}$ & & \\
\hline FUNDAÇÃO GETÚLIO VARGAS & Manual de arquivo da FGV & 1977 & \\
\hline FUNDAÇÃO GETÚLIO VARGAS & $\begin{array}{l}\text { Procedimentos técnicos adotados pelo CPDOC na } \\
\text { organização de arquivos privados contemporâneos }\end{array}$ & 1980 & \\
\hline GAGLIARD, Pedro Luiz Ricardo; ALMEIDA, Wilson Cândido Ferreira & Arquivos judiciários & 1985 & \\
\hline
\end{tabular}




\begin{tabular}{|c|c|c|c|}
\hline Lopes de & & & \\
\hline GONCALVES, Janice & $\begin{array}{l}\text { Como classificar e ordenar documentos de arquivo (Como } \\
\text { Fazer, 2) }\end{array}$ & 1998 & \\
\hline GORBEA, Josefina Q. de & Sistemas de arquivos e controle de documentos & 1979 & 2.ed. \\
\hline $\begin{array}{l}\text { INSTITUTO DE DESENVOLVIMENTO DE RECURSOS HUMANOS } \\
\text { (Distrito Federal, DF) }\end{array}$ & Controle e movimentação de processos & 1980 & \\
\hline $\begin{array}{l}\text { INSTITUTO DE DESENVOLVIMENTO DE RECURSOS HUMANOS } \\
\text { (Distrito Federal, DF) }\end{array}$ & Plano de arquivamento & 1980 & \\
\hline $\begin{array}{l}\text { INSTITUTO DE DESENVOLVIMENTO DE RECURSOS HUMANOS } \\
\text { (Distrito Federal, DF) }\end{array}$ & Princípios arquivísticos & 1980 & \\
\hline $\begin{array}{l}\text { JAMBEIRO, Othon (Org.); GOMES, Henriette Ferreira (Org.); LUBISCO, } \\
\text { Nídia M. L. (Org.) }\end{array}$ & Informação: contextos e desafios & 2003 & \\
\hline JARDIM, José Maria & $\begin{array}{l}\text { Projeto de construção de uma metodologia ibero-americana } \\
\text { de gestão de documentos: relatório da situação dos arquivos } \\
\text { públicos na Argentina, Brasil, Chile e Uruguai }\end{array}$ & 1987 & \\
\hline JARDIM, José Maria & Sistemas e políticas públicas de arquivos no Brasil & 1995 & \\
\hline LASMAR, Denise Portugal & $\begin{array}{l}\text { O acervo imagético da Comissão Rondon no Museu do } \\
\text { Índio: } 1890-1938\end{array}$ & 2008 & \\
\hline LOPES, Luís Carlos & A informação e os arquivos: teorias e práticas & 1996 & \\
\hline LOPES, Luís Carlos & $\begin{array}{l}\text { A gestão da informação: as organizações, os arquivos e a } \\
\text { informática aplicada }\end{array}$ & 1997 & \\
\hline LOPES, Luís Carlos & A imagem e a sombra da arquivística & 1998 & \\
\hline LOPEZ, André Porto Ancona & $\begin{array}{l}\text { Tipologia documental de partidos e associações políticas } \\
\text { brasileiras }\end{array}$ & 1999 & \\
\hline LOPEZ, André Porto Ancona & $\begin{array}{l}\text { Como descrever documentos de arquivo: elaboração de } \\
\text { instrumentos de pesquisa (Projeto Como fazer, 6) }\end{array}$ & 2002 & \\
\hline LUCK, Esther Hermes; JARDIM, José Maria; & A informação: questões e problemas & 1995 & \\
\hline $\begin{array}{l}\text { FREITAS, Lídia Silva de; LOPES, Luís Carlos; BOTTINO, Mariza; } \\
\text { BREGLIA, Vera Lúcia Alves; RODRIGUES, Mara Eliane Fonseca } \\
\text { MACHADO, Helena Correa; CAMARGO, Ana Maria de Almeida }\end{array}$ & Roteiro para implantação de arquivos municipais & 1996 & \\
\hline MACHADO, Helena Correa; CAMARGO, Ana Maria de Almeida & $\begin{array}{l}\text { Como implantar arquivos públicos municipais (Como fazer, } \\
\text { 3) }\end{array}$ & 1999 & \\
\hline MATTAR, Eliana da Silveira (Org.) & Acesso à informação e política de arquivos & 2003 & \\
\hline MENDES, Ubirajara Dolácio & Noções de paleografia & 2008 & 2.ed. \\
\hline
\end{tabular}




\begin{tabular}{|c|c|c|c|}
\hline MUSEU DE ASTRONOMIA E CIÊNCIAS AFINS & Política de segurança para arquivos, bibliotecas e museus & 2006 & \\
\hline MUSEU EUGÊNIO TEIXEIRA LEAL & $\begin{array}{l}\text { Guia de instituições culturais do centro histórico: } \\
\text { questionários aplicados aos técnicos respónsáveis pelas } \\
\text { instituições }\end{array}$ & 1989 & \\
\hline NABUCO, Joaquim & $\begin{array}{l}\text { Em defesa do livro: a conservação das nossas bibliotecas e } \\
\text { arquivos }\end{array}$ & 1959 & 2. ed. \\
\hline NOGUEIRA JUNIOR, Alberto & $\begin{array}{l}\text { Cidadania e direito de acesso aos documentos } \\
\text { administrativos }\end{array}$ & 2003 & \\
\hline PAES, Marilena Leite & Teoria e prática de arquivo & 1978 & 1982 \\
\hline PRADO, Heloísa de Almeida & A técnica de arquivar & 1988 & 5.ed. \\
\hline RIO DE JANEIRO (Estado) & $\begin{array}{l}\text { Secretaria de Estado de Administração e Reestruturação } \\
\text { Manual de avaliação de documentos }\end{array}$ & 2001 & \\
\hline ROLF, Nagel; RICHTER, Eneida Izabel Schirmer & Elementos de arquivologia & s. d. & \\
\hline RONDINELLI, Rosely Curi & $\begin{array}{l}\text { Gerenciamento arquivístico de documentos eletrônicos: uma } \\
\text { abordagem teórica de diplomatica arquivística } \\
\text { contemporânea }\end{array}$ & 2002 & \\
\hline SILVA, Jaime Antunes da & $\begin{array}{l}\text { A política nacional de arquivos: a ação do Conselho } \\
\text { Nacional de Arquivos e do Arquivo Nacional }\end{array}$ & 1996 & \\
\hline SILVA, Jaime Antunes da & $\begin{array}{l}\text { A política de arquivos no Brasil e a sua inserção na América } \\
\text { Latina }\end{array}$ & 1998 & \\
\hline SILVA, Sérgio Conde de Albite & $\begin{array}{l}\text { A preservação da informação arquivística governamental } \\
\text { nas políticas públicas do Brasil }\end{array}$ & 2008 & \\
\hline SILVA, Zélia Lopes da (Org.) & Arquivos, patrimônio e memória: trajetórias e perspectivas & 1999 & \\
\hline SOARES, Iaponan (Org.) & Arquivos \& documentos em Santa Catarina & 1985 & \\
\hline STAMATTO, Maria Inês Sucupira & $\begin{array}{l}\text { A educação no Rio Grande do Norte: fontes oficiais - Século } \\
\text { XIX } 1997 \text { TEXTOS de Arquivologia [UFSM] Textos de } \\
\text { Arquivologia }\end{array}$ & 1997 & \\
\hline UNIVERSIDADE FEDERAL DO PARANÁ & Arquivos paranaenses & 1969 & \\
\hline $\begin{array}{l}\text { VALERIO, Antônio Carlos Gonçalves; CALOU FILHO, José Ivan; SA, } \\
\text { Maria Elisa Noronha de; MARQUES, Regina Celie Simões; SOARES, } \\
\text { Sebastião; FIGUEIRA, Vera Moreira }\end{array}$ & Identificação de documentos em arquivos públicos & 1983 & 1985 \\
\hline
\end{tabular}

Fonte: Marques (2011) 
ANEXO C - Livros da Ciência da Informação citados nas teses (2007-2009)

\begin{tabular}{|c|c|}
\hline Autores & Livro \\
\hline BRIET, Suzanne & Qu'est-ce la documentation? \\
\hline CAMPOS, Maria Luiza & $\begin{array}{l}\text { Linguagem documentária: teorias que } \\
\text { fundamentam sua elaboração }\end{array}$ \\
\hline CASTRO, César & História da Biblioteconomia brasileira \\
\hline CINTRA, Anna M. et al. & $\begin{array}{l}\text { Para entender as linguagens } \\
\text { documentárias }\end{array}$ \\
\hline DOBEDEI, Vera & $\begin{array}{l}\text { Tesauro: linguagem de representação da } \\
\text { memória documentária }\end{array}$ \\
\hline FIGUEIREDO, Nice & Estudos de uso e usuários da informação \\
\hline FOSKETT, Antony & A abordagem temática da informação \\
\hline GIBBONS, Michael & $\begin{array}{l}\text { Innovation and the Developing System } \\
\text { of Knowledge Production }\end{array}$ \\
\hline GROGAN, Denis & A prática do serviço de referência \\
\hline $\begin{array}{l}\text { GUINCHAT, Claire; MENOU, } \\
\text { Michel }\end{array}$ & $\begin{array}{l}\text { Introdução geral às ciências e técnicas da } \\
\text { informação e documentação }\end{array}$ \\
\hline HJORLAND, Birger & $\begin{array}{l}\text { Information seeking and subject } \\
\text { representation: an activity-theoretical } \\
\text { approach to Information Science }\end{array}$ \\
\hline INGWERSEN, Peter & Information retrieval interaction \\
\hline JARDIM, José Maria & $\begin{array}{l}\text { Transparência e opacidade no estado do } \\
\text { Brasil: uso e desusos da informação } \\
\text { governamental }\end{array}$ \\
\hline KUHLTHAU, Carol & $\begin{array}{l}\text { Seeking meaning: a process approach to } \\
\text { library and information services }\end{array}$ \\
\hline LANCASTER, Frederick & Indexação e resumos: teoria e prática \\
\hline LANCASTER, Frederick & $\begin{array}{l}\text { Information retrieval systems: } \\
\text { characteristics, testing and evaluation }\end{array}$ \\
\hline LANCASTER, Frederick & $\begin{array}{l}\text { Vocabulary control for information } \\
\text { retrieval }\end{array}$ \\
\hline LE COADIC, Yves-François & A Ciência da Informação \\
\hline MCGARRY, Kevin & $\begin{array}{l}\text { O conceito dinâmico da informação: uma } \\
\text { análise introdutória }\end{array}$ \\
\hline MEY, Eliane & Introdução à catalogação \\
\hline MIRANDA, Antônio & $\begin{array}{l}\text { Ciência da Informação: teoria e } \\
\text { metodologia de uma área em expansão }\end{array}$ \\
\hline
\end{tabular}




\begin{tabular}{|c|c|}
\hline OTLET, Paul & $\begin{array}{l}\text { Traité de Documentation: le livre sur le } \\
\text { livre: théorie et pratique }\end{array}$ \\
\hline PIEDADE, Maria & Introdução à teoria da classificação \\
\hline PINTO MOLINA, María & Análises documental \\
\hline RANGANATHAN, Shiyali & Prolegomena to library classification \\
\hline ROBREDO, Jaime & $\begin{array}{l}\text { Da ciência de informação revisitada aos } \\
\text { sistemas humanos de informação. }\end{array}$ \\
\hline ROBREDO, Jaime & Documentação de hoje e de amanhã \\
\hline RONDINELLI, Rosely & $\begin{array}{l}\text { Gerenciamento arquivísticos de } \\
\text { documentos eletrônicos }\end{array}$ \\
\hline ROWLEY, Jennifer & A biblioteca eletrônica \\
\hline $\begin{array}{l}\text { SALTON, Gerard; MACGILL, } \\
\text { Michael J. }\end{array}$ & $\begin{array}{l}\text { Introduction to modern information } \\
\text { retrieval }\end{array}$ \\
\hline $\begin{array}{l}\text { SHANNON, Claude; WEAVER, } \\
\text { Warren }\end{array}$ & $\begin{array}{l}\text { The mathematical theory of } \\
\text { communication. }\end{array}$ \\
\hline $\begin{array}{l}\text { SHAPIRO, Carl ; VARIAN, Hal } \\
\text { R. }\end{array}$ & A economia da informação \\
\hline $\begin{array}{l}\text { SILVA, Armando Malheiro; } \\
\text { RIBEIRO, Fernanda }\end{array}$ & $\begin{array}{l}\text { Das "ciências" documentais à Ciência da } \\
\text { Informação: ensaio epistemológico para } \\
\text { um novo modelo curricular }\end{array}$ \\
\hline SORJ, Bernardo & $\begin{array}{l}\text { Brasil@povo.com: a luta contra a } \\
\text { desigualdade na sociedade da informação }\end{array}$ \\
\hline SVENONIUS, Elaine & $\begin{array}{l}\text { The intellectual foundation of } \\
\text { information organization }\end{array}$ \\
\hline VAN SLYPE, Georges & $\begin{array}{l}\text { Los lenguajes de indización: concepción } \\
\text { construcción y utilización en los sistemas } \\
\text { documentales }\end{array}$ \\
\hline VICKERY, Brian & Classificação e indexação nas ciências \\
\hline
\end{tabular}

Fonte: MENEZES, (2012). 